1999

\title{
Rules, Responsibility and Commitment to Children: The New Language of Morality in Family Law
}

Jane C. Murphy

University of Baltimore School of Law, jmurphy@ubalt.edu

Follow this and additional works at: http://scholarworks.law.ubalt.edu/all_fac

Part of the Family Law Commons, and the Juvenile Law Commons

\section{Recommended Citation}

Rules, Responsibility and Commitment to Children: The New Language of Morality in Family Law, 60 U. Pitt. L. Rev. 1111 (1999)

This Article is brought to you for free and open access by the Faculty Scholarship at ScholarWorks@University of Baltimore School of Law. It has been accepted for inclusion in All Faculty Scholarship by an authorized administrator of ScholarWorks@University of Baltimore School of Law. For more information, please contact snolan@ubalt.edu. 

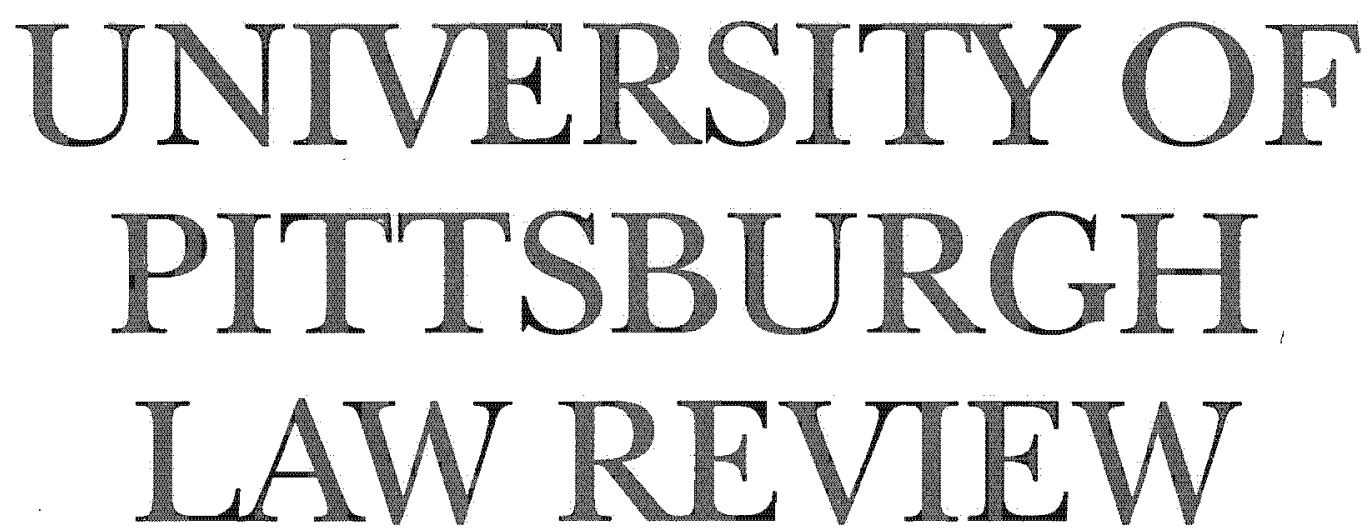

Rules, Responsibility and Commitment to Children:

The New Language of Morality in Family Law

Jane C. Murphy 


\title{
RULES, RESPONSBRITIY AND COMMITMENT TO CHILDREN: THE NEW LANGUAGE OF MORALITY IN FAMUY LAW
}

\author{
Jane C. Murphy*
}

Table of Contents

I. Introduction............................................. 1112

II. Morality and Its Role in Contemporary Family Law ........ 1118

A. Defining Morality ................................... 1118

B. The Relationship Between Law and Morality........... 1126

C. Morality and Family Law .......................... 1127

1. Protecting Children: A Central Moral Goal of Family Law........................................

2. The Link Between Family Law and Morality: Beyond Individual Rights vs. Community Values.... 1130

III. The "Old" Moral Discourse: Regulating Sexual Conduct ... 1134

A. The Meaning of Fault as Grounds for Divorce......... 1136

B. Alimony Law in the Fault Era ...................... 1145

C. Custody in the Fault Era ............................... 1150

IV. The New Moral Discourse in Family Law ................. 1154

A. Access to Marriage .................................. 1155

1. Who May Marry: Same Sex Marriage............ 1156

2. Pre-Marital Procedures: Covenants and Counseling.................................................. 1161

B. Reinforcing Responsibilities and Commitments Within Families................................................. 1165

1. Family Violence ................................ 1165

a. Eroding the Doctrine of Family Autonomy.. 1165

* Professor of Law, University of Baltimore School of Law, B.A. 1975, Boston College; J.D. 1978, New York University School of Law. This article was made possible by a summer research grant provided by the University of Baltimore Educational Foundation. I wish to thank Robert Rubinson, June Carbone, Marsha Garrison, Barbara Babb, and Cheri Wyron Levin for their comments on this article. I also thank Margaret May for her excellent clerical and research assistance and Robin Klein, Will Tress, and Luann Dickie for their research assistance. This article is dedicated to the many children I have represented over the years and, most importantly, to my own four children, who inform and inspire my work in so many ways. 
b. New Laws: Reducing Domestic Violence and Child Abuse............................. 1167

i. Domestic Violence ....................... 1167

ii. Child Abuse ............................. 1169

2. Recognizing Commitment in Families Created Outside of Marriage................................. 1172

C. Family Dissolution ................................... 1175

1. Access to Divorce.................................. 1175

a. What No-Fault Divorce Really Means....... 1175

b. Continued Debate About the Morality of Divorce in the No-Fault Era

2. Protecting Children: Changes in Custody and Visitation Law

a. Developments Encouraging Post Breakup Involvement of Both Parents.

i. Joint Custody

ii. Parenting Classes and Parenting Plans

b. The Child's Voice in Custody Proceedings ..

c. Refining the Best Interest Standard

i. The Nexus Requirement in Determining Parental Fitness.

ii. Primary Caretaker Standard

iii. Recognizing the Connection Between Domestic Violence and Parental Fitness

3. The Child Support Revolution

D. Creating Rights for Family Members: From Discretionary Standards to Rules

V. Conclusion

\section{INTRODUCTION}

In recent years, commentators with a broad range of political perspectives have called for renewed attention to "morality" in family law. This call has been made in a variety of contexts by legal scholars, ${ }^{1}$ politi-

1. See, e.g., Bruce C. Hafen, The Family as an Entity, 22 U.C. DAvis L. REv. 865, 879 (1989) (finding that "[s]tate intervention into family life . . . is less likely now than previously to be based on moral judgments"); Carl E. Schneider, Marriage, Morals \& the Law: No-Fault Divorce and Moral Discourse, 1994 UTAH L. REv. 503 [hereinafter Schneider, Marriage, Morals] (evaluating diminished moral discourse in family law and noting both advantages and disadvantages of the trend); Carl E. Schneider, Moral Discourse and the Transformation of American Family Law, $83 \mathrm{MicH}$. L. 
cians, ${ }^{2}$ and policy makers. ${ }^{3}$ Two concerns about themes of family law commentary emerge from these diverse sources. The first theme argues for a new direction in family policy. Those advocating a change in direction argue that traditional families-two parent, heterosexual married couples with children-are essential to a healthy society and must be encouraged. ${ }^{4}$ They argue that contemporary family laws, most notably nofault divorce and related laws, have contributed to and fostered the decline of the traditional family. ${ }^{5}$ According to these commentators, the

REv. 1803, 1807-20 (1985) [hereinafter Schneider, Moral Discourse] (noting the "tendency toward diminished moral discourse" in family law cases and statutes and the debate surrounding them); Jana B. Singer, The Privatization of Family Law, 1992 Wis. L. REV. 1443, 1527 (1992) (arguing that the "increased dissociation of law and morality ... is directly linked to the privatization of family law"); Lee E. Teitelbaum, The Last Decade(s) of American Family Law, 46 J. LEGAL EDUC. 546, 547 (1996) (noting a decline in moral discourse in some areas of family law); Lynn D. Wardle, Divorce Violence and the No-Fault Divorce Culture, 1994 UTAH L. Rev. 741, 741 (1994) (critiquing the "nofault divorce culture" and suggesting connections between no-fault divorce and violence). But see, e.g., Deborah L. Rhode \& Martha Minow, Reforming the Questions, Questioning the Reforms: Feminist Perspectives on Divorce Law, in DIVORCE REFORM AT THE Crossroads 191, 198 (critiquing the traditional moral judgments in family law as too narrowly conceived); Naomi R. Cahn, The Moral Complexities of Family Law, 50 STAN. L. Rev. 225, 270 (1997) (arguing that moral discourse in family law has evolved rather than diminished in recent decades); Ira Mark Ellman, The Misguided Movement to Revive Fault Divorce, and Why Reformers Should Look Instead to the American Law Institute, 11 INT'L J.L. POL'Y \& FAM. 216, 230-36 (1997) (summarizing proposals adopted by the American Law Institute that remove concepts of fault and marital misconduct from marital property and alimony law).

2. As early as 1980, President Jimmy Carter, speaking from the White House, called for a "reaffirmation of families as a fundamental building block of our society." President Jimmy Carter, Opening Session of the White House Conference on Families, Baltimore, Maryland (June 5, 1980). More recently, both Republicans and Democrats have called for restoration of family values. See, e.g., The Contract with America (July 11, 1998), <http://web.mit.edu/republicans/www/contracthtml>; see also Robert Wright, The False Politics of Values, TIME, Sept. 9, 1996, at 42 (evaluating the bipartisan interest in values and morality).

3. Policy makers cailing for a more explicit integration of traditional values in family policy also cover the full range of the political spectrum. Compare CONTRACT WTTH THE AMERICAN FAMILY (Ralph Reed ed., 1995) with William A. Galston, Liberal. PUrposes: GOOd, VirTues, ANd Diver. STTY IN THE LIBERAL STATE 213-37, 257-89 (1991).

4. Of course, defining "family" is both a critical issue within this debate and one that divides many scholars. Compare Lynn D. Wardle, The Use and Abuse of Rights Rhetoric: The Constitutional Rights of Children, 27 LoY. U. CH. L.J. 321, 327-28 (1996) (arguing that the institution of marriage is integral to familial love and security) with Martha Minow, All in the Family and In All Families: Membership, Loving, and Owing, in Sex. Preference, and Family: Essays on Law and Nature 249, 260 (David M. Estlund \& Martha C. Nussbaum eds., 1997) (arguing for an "expansive" definition of family on the ground that "values signaled by 'family' are worthwhile and . . . should be promoted wherever possible").

5. Another recurring target of this group is welfare and its claimed connection to family disintegration. In recent years, key leaders and policymakers have blamed welfare for social problems like poverty and family violence that contribute to family breakup. See Laurence E. Lynn, Jr., Ending Welfare Reform as We Know It, AM. ProspeCr, Fall 1993, at 84 (finding that a political consensus 
principles of privacy, individual rights and autonomy that underlie the "no-fault revolution"6 should be deemphasized in family law policy. Instead, family law policy should promote a return to traditional principles of right and wrong and marital commitment. ${ }^{7}$

The second theme is voiced primarily by some family law scholars who have identified a change in the language of family law. The decreasing reliance on "fault" in family law over the last few decades, according to these scholars, has resulted in "a diminution of the law's discourse in moral terms about the relations between family members" and the "transfer of moral decisions from the law to the people the law once regulated." These scholars do not claim that contemporary family law lacks a moral justification, nor are they strongly advocating corrective measures. ${ }^{9}$ Rather, they note that the way current family law "expresses

among some liberals and most conservatives has emerged that blames single mothers receiving welfare for "weakened commitment to competence, work, and responsible living" which leads to poverty); Karen Hosler, Dole Draws Fire with Comments on Crime; Candidate Criticized for Appearing to Link Spousal Abuse, Welfare, BALT. SUN, May 31, 1996, at 8A (quoting 1996 presidential candidate Bob Dole who blamed welfare programs for increases in domestic violence); Robert Scheer, Gingrich, Savaging Welfare, Is on a Fool's Errand, L.A. TIMES, Nov. 28, 1995, at B9 (describing Gingrich's false "depiction of [a slain pregnant woman] as the product of an immoral welfare culture"). Of course, families are affected by policies outside the traditional law of domestic relations such as welfare and employment policies. However, a thorough discussion of trends in those laws and their affect on the stability of American families is outside the scope of this Article.

6. The term "no-fault revolution" was originally used by Lenore J. Weitzman in THE DIvORCE REVOLUTION: THE UNEXPECTED SOCIAL AND ECONOMIC CONSEQUENCES FOR WOMEN AND CHILDREN IN AMERICA (1985). That term and other references to the no-fault era throughout this Article refer to the shift from exclusive reliance on fault grounds for divorce to the inclusion of no-fault grounds in all states. This era began in the late 1960 s and was completed in the early 1980s. The term also refers to changes in alimony and marital property laws that occurred during the same period throughout the United States, which deemphasized the role of fault. The term "fault era" as used throughout this Article refers to the period before the no-fault era when fault was a key factor in divorce, alimony, and custody decisions.

7. See, e.g., David Blankenhorn. Fatherless america: Confronting Our Most Urgent Social Problem 20-21 (1995); Gertrude Himmelfarb. The De-Moralization of Society from Victorian Virtues to Modern Values (1995); William A. Galston, Divorce American Style, PUb. INTEREST, Summer 1996, at 12 (suggesting that no-fault divorce and related developments in the law have led to increases in divorce and the weakening of the American family). Of course, concern about the stability of the American family has emerged throughout American history since the Puritans voiced concerns about "fragility of marriage, the growing selfishness and irresponsibility of parents and the increasing rebelliousness of children." ARLENE SKOLNICK, EMBATTLED PARADISE: THE AMERICAN FAMILY IN AN AGE OF UNCERTANTY 8 (1991) (quoting SARA M. Evans, BORN For LiBERTY: A HISTORY OF WOMEN IN AMERICA 63 (1989)).

8. Schneider, Moral Discourse, supra note 1, at 1807; see also Lee E. Teitelbaum, Moral Discourse and Family Law, 84 MiCH. L. REv. 430, 431 (1985) (clarifying the meaning of moral discourse as "the frank invocation by courts of value-laden language to justify both doctrine and particular results").

9. Carl Schneider and Jana Singer, for example, see this trend of diminished moral discourse 
ideas"10-through the language of statutes and judicial decisions-increasingly relies less on moral language, ideas and prohibitions, and more on principles of private ordering and individual freedom. They caution that this may have a negative impact on preserving traditional families.

This Article challenges the assumption that no-fault divorce and related family law developments over the last three decades have signalled a retreat from either a moral vision or moral discourse in family law. Without question, the shift to no-fault divorce has resulted in sweeping changes in both the moral justification underlying family law and the language of the statutes and cases reflecting these developments. The Article maintains, however, that contemporary family law has not retreated from morality; rather, the values that are embodied in both the language of statutes and in judicial opinions have evolved over time and reflect both a broader understanding of morality and a reconceived notion of rights within the family.

Contemporary family law has replaced the emphasis on limiting sexual relations to marriage that characterized the fault era with an emphasis on other values-equality, fairness, responsibility for dependent spouses and, most especially, emotional and financial commitment to children. The language of the laws embodying these new values contains fewer explicit references to morality. But, this new discourse-with its emphasis on obligations, protection, duty, and equality-is the language of an expanded meaning of morality informed by the concept of practicing virtues. Individuals lead moral lives by meeting their duties, treating others fairly and protecting the vulnerable."

The new developments in family law that reflect this changed morality include increased regulation in child custody and visitation, child support, and family violence. Other areas-access to marriage and the rights of cohabitants - have not been dramatically changed in the no-fault era but are being debated in ways that make the moral assumptions underlying the laws more explicit. ${ }^{12}$ The debate about same sex marriage, for example, has forced federal and state legislators, family law scholars, and policymakers to rethink the religious, cultural and, most prominently,

as having both positive and negative consequences for family law. See Schneider, Marriage, Morals, supra note 1, at 503; Singer, supra note 1, at 1527.

10. Schneider, Moral Discourse, supra note 1, at 1827.

11. For a fuller discussion of the meaning of practicing virtues, see infra notes 29-72 and accompanying text.

12. See infra notes $241-312,364-78$ and accompanying text. 
the moral values underlying the institution of marriage. ${ }^{13}$

Finally, this shift in values may also account for an increasing reliance on laws drafted as rules rather than the broad discretionary standards that have traditionally characterized family law. ${ }^{14}$ Movements such as the change from discretionary standards to required formulas for setting child support have conferred new rights on family members, particularly custodial parents and children. ${ }^{15}$ "Rights talk" 16 is often associated with diminished emphasis on morality because focusing on individual rights over family concerns is thought to undermine marriage by encouraging pursuit of self-fulfillment over duties to other family members. ${ }^{17}$ Rights among family members, however, can serve to reinforce the values of equality and commitment. The increased use of rules to create rights and regulate obligations among family members reflects the law's increased concern for enforcing family members' obligations to each family's most vulnerable members, particularly children..$^{18}$

Both the language and the purposes underpinning current standards, however, draw on moral principles. Pursuit of these new values involves greater emphasis on issues that, at first glance, appear more concerned with economic or psychological principles. For example, courts assessing "fault" in a divorce context focus on issues like sexual misconduct. In the no-fault era, courts spend more time on issues like determining income for child support and evaluating parenting skills. To the extent this discourse translates to financial and emotional support for children, it relates to moral issues. This Article concludes that such a shift is desirable because it has the potential to strengthen families-in all their current forms-and their ties to the broader community. Most importantly, this shift is one that furthers what has become the central moral goal of family law: protection of children.

Part One of this Article explores the meaning of morality by briefly reviewing a variety of attempts to explore the meaning of moral conduct. This Section draws on a variety of contemporary moral philosophers who

13. See infra notes $247-80$ and accompanying text.

14. See infra notes 519-65 and accompanying text.

15. See, e.g., Jane C. Murphy, Eroding the Myth of Discretionary Justice in Family Law: The Child Support Experiment, 70 N.C. L. REv. 209, 226-31 (1991).

16. See, e.g., Mary Ann Glendon, Rights TalK: The Impoverishment of Polmtical DisCOURSE (1991) (critiquing what she sees as the American preoccupation with rights, which validates individual, arbitrary preferences rather than teaching collective responsibility and duty); infra notes 89-103 and accompanying text.

17. See infra notes $86-108$ and accompanying text.

18. See infra notes $472-86$ and accompanying text. 
have built on the classical tradition to develop a broader definition of moral behavior. This discussion provides a context for the current debate about the meaning of morality in family law and moral discourse in the no-fault era.

Part One also reviews the historical debate about how law should strike a balance between promoting communitarian values and respecting autonomy and individual rights. The Article argues that the conflict underlying this debate may be overstated. All laws have moral implications, and decisions about law, made by citizens, legislators and policymakers, necessarily involve choices that privilege some values over others. Regulating family members is a particularly value-laden task. A tension will always exist between protecting individual freedom and privacy of family members and state intervention to further the common good. However, this tension does not require a retreat from the concept of rights within the family; rather, rights can be conceived in a way that furthers the moral vision of family law by using rights as a tool to ensure the protection of vulnerable members of the family.

Part One concludes by noting that the hierarchy of values embodied in the moral vision of family law has changed over time. Sexual morality has become less important over time while protecting children has become central to the moral framework of family law.

Part Two of the Article examines the traditional, fault-based moral discourse in the law governing grounds for divorce, alimony and child custody that prevailed in this country until the 1970's. It concludes that this approach has several significant drawbacks. First, the fault-era's emphasis on sexual practices and traditional gendered family roles reinforced patriarchy and tended to hurt custodial parents-primarily women-and children. Additionally, the fault-era's reliance on broad discretionary standards resulted in inadequate financial awards and dual standards for men and women. Further, because moral discourse in family law has been primarily focused on issues of sexual conduct in marriage, the fault-era moral vision excluded families created outside of marriage. Litigating issues of fault also exacted significant financial and emotional costs on families. Finally, the emphasis on regulating sexual conduct in the fault-era did little to promote the evolving moral goal of family law-protecting children.

Part Three of the Article explores the ways in which some laws that developed in the no-fault era express morality in family law. Examining current laws governing divorce, marital property, child support and custody, the Article identifies ways in which both the language surrounding 
the debates about such laws and the laws themselves express values of equality, commitment and responsibility for family members, particularly dependent members. The Article notes that for the first time, the language of morality has expanded into two areas that were largely unregulated in the "fault" era-access to marriage and family violence.

The Article concludes that these developments over the last thirty years represent a healthy trend toward an overall family policy that strengthens families and protects each family's weakest members. Nevertheless, more needs to be done to achieve a family policy that protects children. Finally, the Article identifies additional measures, both in traditional domestic law and in the broader policy arena, that must be accomplished to truly strengthen families, and most importantly, to protect children.

\section{Morality and Its Role in CONTEMPorary Family LaW}

\section{A. Defining Morality}

Before evaluating the changes in the role of morality and moral discourse in family law over the last thirty years, it is necessary to clarify what is meant by morality in this context and how it relates to the law. Until recently, popular debate about morality in this country often focused on sexual practices. ${ }^{19}$ A brief review of moral theory and philosophy reveals a much broader meaning of morality, which is beginning to be reflected in law and social policy.

Defining morality is a challenging task. Efforts to formulate principles of moral behavior have occupied cultures throughout the history of

19. Carl Schneider sees this limited view of morality as part of a recent trend that signals a change in "the social position of moral discourse. ... [T] he very term 'moral' has in some milieux taken on a narrow-and derogatory-meaning. Specifically, it is at best confined to questions of sexual morality. 'Morality' means 'traditional morality' which means sexual morality." Schneider, Marriage, Morals, supra note 1, at 537. Although Schneider suggests that the association of morals with sexual practices helps to account for the recent decline in moral discourse in family law, he notes that similar observations were made by commentators almost seventy years ago. See id. at $537 \mathrm{n} .77$ (citing Walter LIPpMan, A PREFace to Morals 285 (1929) ("[I]n the popular mind it is immediately assumed that when morals are discussed it is sexual morals that are meant.")); see also Michael J. Meyer, Family Virtues and the Common Good, 36 SANTA ClarA L. Rev. 409, 413 (1996) ("[T]he entire realm of virtues is often reduced . . . into one subset, such as sexual virtues, teenage chastity or marital fidelity."); Kenneth L. Woodward, What Is Virtue?, NEwsweEK, June 13, 1994, at 38 (comparing the modern American association of virtue with "sexual purity" to the ancient Greeks, medieval theologians and some contemporary moral philosopher's association of virtue with the "good person"). 
humankind. ${ }^{20}$ Even a modest attempt to draw from the major Western schools of moral philosophy, which have influenced the contemporary debate about morality and families, would require a review of the ethical traditions of classical Greece, medieval Christendom, the natural law moral philosophers of seventeenth and eighteenth century Britain, the utilitarian school, and the rational or Kantian school of thought. ${ }^{21} \mathrm{~A}$ detailed and thorough review of the ethical traditions represented by these cultures and schools of thought, much less including the many modern strains of non-Western thought that have influenced these debates, is beyond the scope of this Article. ${ }^{22}$ There are, however, central themes or issues that emerge from these traditions that provide insight into both the general debate about morality and the debate within family law.

One dimension of morality relates to its meaning as a code or set of rules that determines "right" and "wrong" behavior. ${ }^{23}$ Under this meaning of morality, which most closely resembles the approach during the fault era in family law, the primary value of a moral code is to identify conduct that should be punished or, to a lesser extent, rewarded. ${ }^{24}$

A broader meaning of morality, one that offers much greater potential for family law, relates to the concept of practicing virtue. ${ }^{25}$ One must

20. See generally Alasdair Macintyre, A Short History of Ethics: A History of MORAL PhILosophy From the Homeric Age to the Twentieth Century (2d ed. 1998).

21. See generally John FinNis, Fundamentals of ETHICs (1983).

22. For a summary of these ethical traditions, see generally FinNIs, supra note 21; MACINTYRE, supra note 20.

23. The term "moral" can be defined as "of or relating to principles of right and wrong behavior ... expressing or teaching a conception of right behavior." WEBSTER's NEw COLIEGIATE Dic. TIONARY 748 (5th ed. 1977). Alan Wolfe defines a moral code as "a set of rules that define people's obligations to one another." Alan Wolfe, Whose KeEPER? Soctal SCIENCE AND MORAl Obligation 2 (1989); see also Schneider, Moral Discourse, supra note 1, at 1827 ("A decision made on moral grounds turns on whether particular conduct is 'right' or 'wrong,' whether it accords with the obligations owed other people or oneself.").

24. See, e.g., LON L. Fuller, The MoraltTy of Law 30 (1969) (describing this approach to morality as the "morality of duty").

25. Terms like values, virtue, and morality are used somewhat interchangeably in much of the literature on this topic and in this Article. While the word "values" may simply connote one's preferences, its recent use in phrases like "family values" has given it a meaning that approximates "virtue." See, e.g., Hugh Leavell, Forget Family Values, Marital Values Hold Key, SAN DiEgo UNION-TRIB., Mar. 9, 1996, at E3 ("The cry for 'family values' is heard across the land."). To the extent one understands morality as the practice of virtue, virtues and values are also linked to the term morality.

The subject of morality and its relationship to virtues and values have enjoyed a resurgence of interest among politicians and scholars in recent years. For a discussion of politicians' current "relentless" interest and discussion of morality, values and virtue, see Sherry Bebitch Jeffe, The Lazy Politician's Way to Win: Embrace Virtue, L.A. TMES, Aug. 14, 1994, at M6; Susan Reimer, Virtue Has Become a Growth Industry, BALT. SUN, Nov. 21, 1995, at 1E; Woodward, supra note 19, at 38; 
begin with the ancient Greeks' and the medieval theologians' understanding of the pursuit of virtue as essential to attaining the "Good Life" in order to understand how little the ideal of sexual purity, which was the focus of moral inquiry in the fault era, expresses about this broader concept of morality. ${ }^{26}$ Under this classical view, moral individuals are those who strive for excellence and the full realization of human potential. ${ }^{27}$ Many contemporary moral philosophers ${ }^{28}$ have embraced this tradition that views practicing virtues as the path to personal happiness and makes people, among other things, responsible citizens and parents. ${ }^{29}$

Which virtues to practice constitutes much of the debate among those philosophers and cultures that ascribe to the concept of the good life. ${ }^{30}$ No tradition places primary emphasis on sexual purity; the concepts covered by the term virtue cover a much broader range of behavior. ${ }^{31}$ Alasdair MacIntyre has attempted to delineate the differences and

Wright, supra note 2 , at 42 . Both scholarly and popular press books on virtue and morality have also flooded the market. See generally WLLIAM J. BENNETT. THE BOOK OF VIRTUES: A TREASURY OF Great Moral Stories (1993); A Call To Character (Colin Green \& Herbert Kohl eds., 1995);

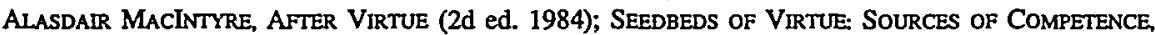
Character, and Cittzenship IN American Society (Mary Ann Glendon \& David Blankenhom eds., 1995); James Q. Wilson. The Moral Sense (1993); VIrTue (John W. Chapman \& William A. Galston eds., 1992).

26. See St. Thomas aquinas, The 'Summa Theologica' of St. Thomas aquinas (Bums, Oates \& Waskburn, 1915); ARISTOTIE, The BASIC WORKS OF ARISTOTIE (W.D. Ross trans., 1941).

27. Immanuel Kant, although often associated with an emphasis on moral law or codes, echoes this view that conforming to rules about right and wrong is not itself central to the moral or good life. See Immanual Kant, Gesammelte Schriften (Prussian Academy 1923), cited in George armstrong Kelly, Idealism, Polmics and History: Sources of Hegelian Thought (1969). Instead, obeying the rules is only important insofar as it prepares man to aspire to a life of virtue and goodness. See id.

28. See, e.g., MACINTYRE, supra note 20; Martha C. Nussbaum, Aristotelian Social Democracy, in LiBerAlism AND THE GOOD 203 (R.B. Douglass et al. eds., 1990); James Q. Wilson, The Family-Values Debate, COMMENTARY, Apr. 1993, at 24.

29. Lon Fuller's description of the two dimensions of morality - the "morality of duty" and the "morality of aspiration"-helps to clarify this dual meaning of morality:

The morality of aspiration is most plainly exemplified in Greek philosophy. It is the morality of the Good Life, of excellence, of the fullest realization of human powers. . . . Where the morality of aspiration starts at the top of human achievement, the morality of duty starts at the bottom. It lays down the basic rules without which an ordered society is impossible. . .

Fuller, supra note 24, at 5; see also Richard B. BRANDT, ETHCAI THEORY: THE PROBLeMs of NorMATIVE AND CRTICAL ETHICs 356-68 (1959) (comparing the dimension of morality that imposes duties or rules with the morality that encourages excellence and aspiring to one's fullest potential); J.M. Findlay, Values and Intentions (1961); W.D. Lamont, The PRinciples of Moral Judgment (1946); A.D. Lindsay, The Two Moralities: Our Duties to God and Society (1940); A. MACBEATH, EXPERIMENTS IN Living 55-56 (1952); JefFrey Reiman, Justice and MODERN MORAL PHLLOSOPHY 40-42 (1990).

30. See MACINTYRE, supra note 25 , at 181-203.

31. See id. at 121-80; see also VIRTUE, supra note 25. 
similarities in the conceptions of virtue from a variety of Western thinkers, ranging from Aristotle to Benjamin Franklin.32 Identifying individual virtues within the cultures represented by these thinkers, MacIntyre notes some of the differences in each culture's "lists of . . . virtues." ${ }^{33}$ As an example, he notes that the New Testament praises humility as a virtue, while Aristotle would include it as one of the vices related to magnanimity. ${ }^{34}$ Benjamin Franklin's list of thirteen virtues for private moral accounting includes some virtues not mentioned in Aristotelian or biblical lists (cleanliness, silence, industry) and others (the drive to acquire) that the ancient Greeks had considered vices. ${ }^{35}$ MacIntyre summarizes the different approaches to virtue represented by this "relatively coherent tradition" of Western thought:

We thus have at least three very different conceptions of virtue to confront: a virtue is a quality which enables an individual to discharge his or her social role (Homer); a virtue is a quality which enables an individual to move towards the achievement of the specifically human telos whether natural or supernatural (Aristotle, the New Testament and Aquinas); a virtue is a quality which has utility in achieving earthly and heavenly success (Franklin). ${ }^{36}$

MacIntyre concludes that despite the differences in individual virtues represented by these three conceptions, they share a core concept of virtue-that the value of practicing an individual virtue must be measured by how such practice contributes to the good of one's whole life. ${ }^{37}$ Under this conception, while practicing the individual virtues is worthwhile for its own sake, what is most important is how the virtues contribute to the ultimate goal of living a unified, good life. ${ }^{38}$

This concept of practicing virtues can only work in a society that shares the "[same] overriding conception of the telos of a whole human life"39 or "shared moral first principles." 40 The belief that certain choices are morally superior to others was first challenged by the moral and po-

32. See MACINTYRE, supra note 25 , at $181,185$.

33. Id. at 181 .

34. See id. at 182 .

35. See id. at 182-183.

36. Id. at 185.

37. See id. at 185-203.

38. MacIntyre ultimately concludes that, because modem American society lacks a shared concept of the Good Life, this tradition of practicing the virtues to achieve a shared societal vision of the ideal life has no place in contemporary American culture. See id. at 252-55.

39. Id. at 202.

40. Id. at 253 . 
litical philosophers during the Enlightenment-Locke ${ }^{41}$ and his intellectual descendants, Mill ${ }^{42}$ and Dworkin ${ }^{43}$-who believed in tolerance for each individual's creeds and belief systems. ${ }^{44}$ This belief in moral relativism makes it difficult, if not impossible, to define a society's core values. ${ }^{45}$ Further, even if a society can be said to share a moral code at a given time, many moral philosophers believe new experiences and knowledge may change both the hierarchy of values and the values themselves. ${ }^{46}$

Much of the rhetoric about virtue or values in the United States today is really an attempt to reinstitute the classical and medieval Christian tradition of transforming certain political issues, for example same-sex marriage and abortion, into issues that can be resolved by the invocation of moral principles. ${ }^{47}$ More specifically, the debates within family law concern the evolution of values that have shaped the law's vision of the ideal family. ${ }^{48}$ The vision has moved from one that is fixed, relying upon natural law principles to determine the roles and obligations of family members, ${ }^{49}$ to a recognition that both the composition and the functions of families in contemporary American society have changed in recent de-

41. See Richard AschCraft, Locke's Two Treatises of Government 97-121 (1987).

42. See C.L. TEN, MRL ON LIBERTY 14-18 (1980).

43. See generally Ronald DWORKIn, A MATTER OF PRINCIPLe (1985).

44. See, e.g., ERnSt CAssirer, The PhILOSOPHY of the ENLIGHTENMENT 160-81 (1951).

45. See, e.g., MACINTYRE, supra note 25 , at 252-53.

46. The transcendentalist view that certain supreme values exist in nature to be discovered and conformed to is represented by both religious and secular philosophers. See AQUINAS, supra note 26; KaNT, supra note 27 , at 112-13. This view is to be contrasted with the empiricist view that an individual's or a culture's moral code can change over time as a result of new experience and knowledge. See, e.g., David Hume, A Treatise of Human Nature (1739). For an interesting contemporary discussion of the transcendentalist vs. empiricist view of moral codes, see Edward $\mathrm{O}$. Wilson, The Biological Basis of Morality, ATLANTIC MONTHLY, Apr. 1998, at 53 (focusing primarily on a related debate concerning the process by which individuals or societies acquire their moral codes).

47. See, e.g., Wilson, supra note 28 , at 24.

48. See, e.g., Cahn, supra note 1 , at 270.

49. See Teitelbaum, supra note 8 , at $432-34$ (summarizing the line of 19 th century United States Supreme Court cases that reflect a "teleological" view of the family drawn on natural law and Christian principles of what constitutes the "good family.") This view is perhaps most clearly reflected in the late nineteenth century Supreme Court case Bradwell v. Illinois:

[T] he civil law, as well as nature herself, has always recognized a wide difference in the respective spheres and destinies of man and woman. ... The constitution of the family organization, which is founded in the divine ordinance, as well as in the nature of things, indicates the domestic sphere as that which properly belongs to the domain and functions of womanhood.

83 U.S, 130, 141 (1872) (Bradley, J., concurring in majority opinion sustaining a state's right to deny women access to the practice of law). 
cades. $^{50}$ While many commentators attribute changes in family structure to economic and political conditions, ${ }^{51}$ such changes may also be attributed to changes in the hierarchy of values within many Western countries over the last few decades. ${ }^{52}$ For example, greater emphasis on equality and faimess and diminished concern for regulation of sexual conduct are shifts in values that have been reflected in family life. ${ }^{53}$

Much of contemporary moral philosophy represents an attempt to reinvigorate the concept of morality as the practice of virtues. ${ }^{54}$ These philosophers have attempted to catalogue the central virtues of contemporary American culture within the "vast reaches of the realm of morality." 55 While sexual fidelity in marriage still occupies a place in the moral dialogue in this country, there is strong evidence suggesting it is not a core or central value among most Americans. ${ }^{56}$ Instead, over the last several

50. See generally SPECIAL REPORT, Single Parents, AMERICAN DEMOGRAPHICs, Dec. 1993, at 36 (finding that "other families"-households of people not headed by married couples-should grow faster than the average household between 1990 and 2010, gaining share from 15 percent to 16 percent of all households); Lee E. Teitelbaum, The Family as a System: A Preliminary Sketch, 1996 UTAH L. REv. 537, 539 (examining patterns of change in family structure and finding that most drastic changes have occurred in the "internal activities of families and the external conditions that account for their structure and composition"). But see Barbara Bennett Woodhouse, "It All Depends on What You Mean by Home": Toward a Communitarian Theory of the "Nontraditional" Family, 1996 UTAH L. REv. 569, 570 (arguing that "nontraditional" label for nonmarital family is a misnomer, because such households have existed "for all of human history").

51. See, e.g., Georgia Dullea, Wide Changes in Family Life Are Altering the Family Law, N.Y. TIMES, Feb. 7, 1983, at Al.

June Carbone has argued that a major factor in the current change in sexual mores-including the increased incidence of divorce-is the change in material conditions. These changes, including longer life spans, more effective contraception and delays in childbearing have increased the potential length of marriages and the opportunities for multiple relationships. See June Carbone, Morality, Public Policy and the Family, 36 SANTA ClaRA L. REv. 267, 278 (1996).

52. See, e.g., P.S. ATIYAH, LAW AND MODERN SOCIETY 114-19 (1983) (describing changes in laws concerning marriage and divorce as changes resulting from shifts in a "community's value system" and noting that such changes in the law are more "deep-seated" and irreversible than changes resulting from economic or social change).

53. See id.

54. See generally MACINTYRE, supra note 25.

55. Meyer, supra note 19, at 413.

56. See, e.g., ATYYH, supra note 52, at 119 (identifying "changing values about sexual behavior" as evidenced by the fact that "[a]dultery is no longer the heinous social and legal offense it was"); Nancy Gibbs, In a Breathtaking Reversal of Fortunes, Clinton's Popularity Soars While Starr Gets Stuck in the Mud, TiME, Feb. 9, 1998, at 28 (noting that a week after the Monica Lewinsky sex scandal broke, President Clinton achieved the highest approval ratings of his five-year presidency and that "Americans are less puritanical and more forgiving than the cartoon version suggests"); Cal Thomas, Let's All Get in Moral Shape, Buffalo News, Feb. 11, 1998, at C3 (discussing the impact of allegations of adultery on the part of President Clinton and Democratic National Committee Chairman and Colorado Governor Roy Romer and commenting that "[w]orse than adulterous behavior is the growing acceptance of it by the public"). 
decades, American society has placed increasing importance on the values of fairness, equality and compassion. Evidence of this general shift in values comes from both public opinion and scholarship. Measuring public opinion on such complex issues as equality and fairness is difficult, but some evidence exists that equality in family relations is valued in theory, if not always in practice, by Americans. ${ }^{57}$

Evidence of this trend among academics is easier to identify. Contemporary philosopher Michael Meyer includes among his representative set of "moral or ethical virtues" which may contribute to the good lifebenevolence, civility, compassion, fairness, and tolerance..$^{58}$ In The Moral Sense, James Q. Wilson identifies what he considers four primary examples of our "moral sense": sympathy, fairness, self-control and duty. ${ }^{59}$ Drawing on the classical tradition, Wilson explains that practicing these four virtues does not always result in laudable conduct; rather, these character traits predispose us to moral conduct. ${ }^{60}$ As Wilson puts it, "[t]emperate people are more likely to keep promises, resist temptations, and reciprocate our affections than are intemperate ones; sympathetic people are more disposed to help us when we are in need and to take our feelings into account than are hard-hearted ones."61

Feminist moral philosophers have also added to the vocabulary of moral discourse by adding the virtue of "care" to the list of core values, recasting traits like good parenting as "virtues":

Traditional moral theorists, with a few exceptions, often see morality as composed of constraints that limit our pursuits of what we desire. Feminist moral theorists, in contrast, often stress the value of good relationships-whether personal or civiland of good parenting and emotions conducive to leading admirable lives. And we stress that these are moral values. ${ }^{62}$

57. See Jennifer L. HochschIld, What's Fair? American Beliefs About Distributive Jus. TICE 107 (1981) (studying Americans' attitudes toward distributive justice and finding that participants favored strict equality in the family); see also RANDOLPH TRUMBACH, THE RISE OF THE EGALITARIAN FAMLY (1978) (noting that the parent-child relationship has become more egalitarian). But see Arlie Hochschild, The Second Shift: Working Parents and the Revolution at Home (1989) (citing examples of families that do not favor equality).

58. See Meyer, supra note 19, at 413-14.

59. See Wnson, supra note 25 , at xiii. Wilson defines "moral sense" as "an intuitive or directly felt belief about how one ought to act when one is free to act voluntarily." Id. at xii.

60. See id. at 82.

61. Id.

62. Virginia Held, Justice and Care 3 (1995); see also Robert E. Goodin, Protecting the VULNERABLE: A REANALYSIS OF OUR SOCIAL RESPONSIBILITIES 28-41 (1985) (arguing that our primary moral obligation is to care for the vulnerable, particularly children). 
Philosophers more closely associated with the liberal tradition have also contributed to the debate about core American values. In A Theory of Justice, John Rawls offers fairness as the intrinsic good, suggesting that it is the moral imperative all would follow if we had no information about our status or place in society. ${ }^{63}$

Ross Evans Paulson identifies "liberty, equality and justice" as the "core values" of modern American society.64 In his review of various social reform movements between 1865 to 1932, Paulson contends that the potential success of these movements depends upon shifts in both the meaning of these concepts and the ranking among them. ${ }^{65} \mathrm{He}$ ends his analysis at mid-twentieth century, noting that the core values still stood, but a shift was beginning in both the meaning and priority many Americans placed on these core values:

\begin{abstract}
Americans wrestled anew with the conflict between the priorities of liberty and equality and the practical meaning of justice. Only gradually would some begin to understand ... that in liberty interdependence was more important than individual independence in maintaining cultural traditions and social institutions. Only painfully would a few people face the issue that liberty as a social goal was something more than freedom from external governmental restraint. It could also include freedom from segregation, discriminatory employment, or negative stereotypes as well. . . . Only haltingly ... did the American political system and culture begin to recognize that justice was not simply adherence to a set of procedures (due process) or a tenuous equity (reward proportionate to effort or "faimess"). Justice was also a matter of the standards, of the expectations applied to all levels, of constitutional phrases turned into daily practices, protected by courts and undergirded by a sense of community. ${ }^{66}$
\end{abstract}

The core values in contemporary American society, then, have shifted over time. They now embody both communitarian values-compassion, duty, and care-and more liberal values-equality, fairness, and justice.

63. See JoHN A. Rawls, A TheORY of Justice 111-14 (1971); see also John Rawls, Kantian Constructivism in Moral Theory, 77 J. PHIL 515, 520-22, Sept. 1980; John A. Rawls, Justice as Fairness: Political not Metaphysical, PHIL. \& PUB. AfFaIRS, Summer 1985, at 223-51 (supporting the justice as faimess theory more on its utility in a pluralistic society such as modern America than on the fact that it reflects "commonly shared presumptions").

64. Ross Evans Paulson, Liberty, EqualtT, and Justice: Civil Rights, Women's Rights, AND THE REGULATION OF BUSINESS, 1865-1932, at 2 (1997).

65. See id. at 2-3.

66. Id. at $244-45$ (emphasis omitted). 


\section{B. The Relationship Between Law and Morality}

Identifying a society's core values-an uncertain task in a pluralistic country like the United States-is only part of the analysis. The next and related question is what the role of law should be in defining or promoting the society's morality or core values. The relationship between law and morality has prompted considerable debate over several centuries. ${ }^{67}$ For the early classical philosophers, the primary purpose of the State was to promote virtue. ${ }^{68}$ By punishing bad acts, the law "stimulate[d] men to virtue and urge[d] them forward by the motive of the noble." 69 The belief that a central connection exists between law and morality was challenged by the liberal tradition so strongly associated with nineteenth century philosopher John Stuart Mill's "harm principle," which asserts that government should remain neutral on moral questions and interfere with a citizen's liberty only to prevent harm to others. ${ }^{70} \mathrm{~A}$ slightly different and more contemporary version of the "harm principle" is exemplified by the mid-twentieth century views of H.L.A. Hart. ${ }^{71}$ Hart developed the view that legal enforcement of morality is not necessary to prevent a society's disintegration and that a pluralistic society with competing moral visions can both survive and flourish. ${ }^{72}$

67. See Roscoe Pound, Law and Morals 125-53 (Augustus M. Kelley ed., 1969) (1924).

68. See ARISTOTLE, supra note 26 , at xxviii.

69. ARISTOTLE, supra note 26, at 1109 (quoting Nicomachean Ethics X. 9 1180a); see also RoBerT P. GEORGE, MAKING MEN MORAL 19-47 (1993) (analyzing the writings of Aristotle and Aquinas as providing Western thought's "central pre-liberal tradition"). This classical view of the absolute link between law and morality was carried forward in medieval England:

On this medieval view, as on the ancient, there is no room for the modem liberal distinction between law and morality, and there is no room for this because of what the medieval kingdom shares with the polis, as Aristotle conceived it. Both are conceived as communities in which men in company pursue the human good and not merely as-what the modem liberal state takes itself to be-providing the arena in which each individual seeks his or her own private good.

MACINTYRE, supra note 25, at 172.

70. See JoHN STUART MIIL, ON LIBERTY 13 (1955).

71. See generally H.L.A. HART, LAw, LibERTY, AND MORALITY (1963) [hereinafter HART, LAW]; see also H.L.A. Hart, Solidarity and the Enforcement of Morality, 35 U. CH. L. REv. 1, 8-13 (1967). Hart's views were challenged by Patrick Devlin, a British High Court Judge, who believed that government should enforce a society's core moral values, not because of the intrinsic truth of the moral choices, but as a means of protecting the society's cohesion. See PATRICK DeVIIN, THE ENForcement OF MORALS 9-11 (1965). The Hart-Devlin debate has been characterized as "one of the most remarkable debates in the history of English speaking jurisprudence." GEORGE, supra note 69, at 49 . For an interesting examination of the debate and its place in contemporary moral theory, see id.

72. See generally HART, LAW, supra note 71. Still other moral and political philosophers argue that the question of whether the government, through its legal system, should promote morality is rendered moot by the lack of moral consensus in this country. Thus, the function of the state through 


\section{Morality and Family Law}

\section{Protecting Children: A Central Moral Goal of Family Law}

The questions raised over the last several centuries about both the meaning of morality and the law's role in supporting a society's morals resonate in family law today. Are there central moral truths that justify the State's interference and regulation of family life or should the law respect private choices and resist enforcing a moral code unless the breach of the code harms a fellow citizen? If State intervention is justified, can the State effectively intervene to promote moral behavior in families? Is "moral behavior" limited to punishing bad acts like sexual misconduct? Or can the virtues of commitment, responsibility and fairness translate into family law?

Turning first to the question whether there are central moral truths in this country with regard to families, there is substantial evidence of deep division on key issues like the importance of marriage and the definition of family ${ }^{73}$ However, there is some evidence that concepts like responsibility, equality, and commitment, particularly to children, now have greater meaning in defining morality in family law than condemnation of

its courts is "to conceal the depths of our conflicts . . . and . . . play the role of a peace-making or truce-keeping body by negotiating its way through an impasse of conflict, not by invoking our shared moral first principles. For our society as a whole has none." MACINTYRE, supra note 25, at 253. MacIntyre, like many other communitarians, laments the current dissociation of law and morality and would prefer to see the state take a more active role in promoting morality. See id.; see also GLENDON, supra note 16 (calling for the law to shoulder more of the burden shared with religion and custom in promoting community values).

73. Martha Minow is one of the commentators who has identified this deep division. She suggests that this lack of consensus on issues like the definition of family suggest that no group or individual advocating a particular definition of family can claim "their own preferences as natural, consensual or obvious." Minow, supra note 4, at 305. For another view that finds less conflict among Americans on family and other issues, see generally ALAN WOLFE, ONE NATION. AFTER ALL: WHAT Middle-Class americans Really Think About: God, Country. Family, Racism, Welfare, ImmlGRATION, HomosexualtTy, WORK, THE Right, tHE LEFT, AND EACH OTHER 278 (1998) (finding after 18 months of research examining 200 people clustered in communities around the country that Americans are "[r]eluctant to pass judgment, ... a are tolerant to a fault, not about everything ... but about a surprising number of things, including rapid transformations in the family"). While this tolerance for other peoples' values and beliefs is viewed as a virtue by Alan Wolfe, others condemn such "moral relativism." See, e.g., WnSON, supra note 25 , at 10 . Several commentators assert that American society is too fragmented and too focused on the issue of cultural diversity, with no strong concept of community. See, e.g., ROBERT N. BELLAH ET AL., HABITS OF THE HEART: INDIVIDUALISM and Commitment in American Life 155-62 (1985); Amital Etzioni, The Spirt of Community: Rights, Responsibilties AND THE CoMMunItARIAN AGENDA 1-20 (1993); John Leo, Sneer Not at Ozzie and Harriet, U.S. News \& WORLD ReP., Sept. 14, 1992, at 24; George F. Will, Circus of the Century, WASH. Post, Oct. 4, 1995, at A25. 
adultery and other sexual misconduct. ${ }^{74}$ There is also an emerging consensus about the centrality of protecting children as, perhaps, the core value that should be promoted in family law. ${ }^{75}$ Again, public opinion polls provide some support for this assertion. ${ }^{76}$ Such polls indicate Americans believe that providing emotional and financial support for children are Americans' primary concerns. ${ }^{77}$

This theme of increasing concern for children as the central goal of family law also runs through contemporary family law scholarship and many policy papers. Mary Ann Glendon was one of the first family law scholars to suggest a "children first" principle in the context of income allocation after divorce:

All property, no matter when or how acquired, would be subject to the duty to provide for the children. Nor would there be any question of "spousal support" as distinct from what is allocated to the custodial spouse in his or her capacity as physical custodian. In cases where there is significant income and property left over after the children's needs have been met, the regular system of marital property division and spousal support law could be applied as a residual system. ${ }^{78}$

Challenging family law scholars to rethink the moral justifications for family law, June Carbone acknowledges conflict among scholars and policymakers on most family law issues. ${ }^{79}$ She suggests that the only area

74. See supra notes $53-66$ and accompanying text.

75. See infra notes $76-85$ and accompanying text.

76. Marsha Garrison has gathered much of the existing data on public opinion on many family law issues. See Marsha Garrison, An Evaluation of Two Models of Parental Obligation, 86 CAL. L. Rev. 41, 116 \& n.334 (1998) (citing HaRT \& TEETER REsEARCH COMPANIES National Telephone Survey of 1502 Adults for NBC News and Wall Street Journal, Question 59 (June 17, 1994) (reporting that, in response to question on effectiveness of "several actions the government might take to try to strengthen families and family values," $49 \%$ of the respondents rated "tougher laws to help collect money from parents who do not make their child support payments" as "very effective," and an additional 19\% rated them as "fairly effective")); see also Mellman \& Lazarus, Mass Mutual American Family Values Study (1989) (describing results of survey commissioned by Massachusetts Mutual Life Insurance Company in which most respondents ranked "[b]eing responsible for your actions," and "[b]eing able to provide emotional support to your family," as their most important personal values while "[b]eing free of obligations so I can do whatever I want to do" came in last).

77. See supra note 76 and accompanying text.

78. Mary ANn Glendon, Abortion and Divorce in Western LaW 95 (1987); see also Mary Ann Glendon, Family Law Reform in the 1980's, 44 LA. L. REv. 1553, 1557-65 (1984); Mary Ann Mason, Motherhood v. Equal Treatment, 29 J. FAM. L. 1, 19 (1990-91).

79. See Carbone, supra note 51, at 281; June Carbone, From Partners to Parents: The SECOND REvOLUTION IN FAMILY LAW (forthcoming 2000) (maintaining that the moral center of family law has shifted from adult partnerships to parental ties); see also June Carbone, Child Custody and the Best Interests of Children, 29 FAM. L.Q. 721, 737 (1995) (reviewing MARY ANN MASON, From FATHER's Property to ChILdRen's Rights: The History of ChILD Custody in the UNTTEd STATES (1994)) [hereinafter Carbone, Child Custody] (arguing that custody law should speak in terms 
of potential agreement is likely to be "an insistence on the importance of and obligation to children." 80 Examining family policy from a philosophy perspective, Michael Meyer is even more explicit when identifying the "optimal type of moral language to discuss the family and its future":

I only wish to claim that the one virtue, the nurturing of children ... ought to be included in our list of the central or the cardinal virtues. Indeed, even if one wishes to distinguish between public virtues and private virtues, the virtue of nurturing children belongs high on both lists. ${ }^{31}$

More recently, Naomi Cahn has suggested that the debates that are often phrased as " 'self-centered individualism' " and " family values' " are really competing visions of the family that share the same central goal of protecting children..$^{22}$

This consensus about the centrality of protecting and nurturing children goes beyond academics. William Galston, former Domestic Policy Advisor to President Clinton, identifies the central goal of family policy to be "rais[ing] children well." ${ }^{83} \mathrm{He}$ advocates policies that "join the languages of economics and morals" to achieve this central goal. ${ }^{84}$ The

of children's needs rather than children's rights).

80. Carbone, Child Custody, supra note 79, at 737; see also Rhode \& Minow, supra note 1, at 198 (arguing that "the moral obligations [under current family law standards] should embody clearer commitments to equality between the sexes and the quality of life for children"); see generally James G. Dwyer, Parents' Religion and Children's Welfare: Debunking the Doctrine of Parents' Rights, 82 CAL L. REv. 1371 (1994) (arguing that talk of parents' rights should be abandoned and replaced with language of parental privilege to care for children in ways that are consistent with their temporal interests); Harry Krause, "Family Values" and Family Law Reform, 9 J. ConTeMP. HeALTH L. \& PoL. 109, 128 (1993) ("[T]he social contract must retum to one basic value judgment: Each child must be guaranteed a decent opportunity in home and school, in life and the economy."); Barbara Bennett Woodhouse, Hatching the Egg: A Child-Centered Perspective on Parents' Rights, 14 CARDOZo L. Rev. 1747, 1748-49 (1993) (arguing that "it is parents' rights, as currently understood, that undermine those values of responsibility and mutuality necessary to children's welfare"). But see Scott Altman, Should Child Custody Rules Be Fair?, 35 J. FAM. L. 325, 354 (1997) (arguing that, while the "yearning to promote only one value nuns deep ... [a]mong principles we might valorize as paramount, protecting children and other vulnerable people is surely worthy. But as with any value, the needs of children must sometimes compete for moral attention") (footnotes omitted).

81. Meyer, supra note 19, at 413-14. See also WiLson, supra note 25, at 249 (defining familes as "a human commitment designed to make possible the rearing of moral and healthy children" and stating that concem for children is "the primary-maybe only-reason for government to be concerned with families").

82. See Cahn, supra note 1, at 225; see also Garrison, supra note 76 , at 102-05 (arguing that the emergence of a child-centered approach in family law scholarship generally supports a community-based child support model).

83. William A. Galston, Home Alone, New Republic, Dec. 2, 1991, at 43; see also David Blankenhorn et al, Regullding the Nest: A New Commitment to the American Famil (1990); Richard T. Gill, For the Sake of the Children, 108 PUBLIC INTEREST 81 (1992).

84. Galston, supra note 83 , at 43 . 
moral importance of caring for children has also been noted by politicians and the highest elected officials. ${ }^{85}$

\section{The Link Between Family Law and Morality: Beyond Individual Rights vs. Community Values}

Turning next to the question of whether the law can or should promote these values, some scholars and policymakers argue that the law's ability to promote moral behavior is very limited. ${ }^{86}$ Mary Ann Glendon has highlighted the limited role family law has played in promoting morality: "Much of family law is no more-and no less-than the symbolic expression of certain cultural ideals . . . Probably no other area of law is so replete with legal norms that communicate ideas about proper behavior but that have no direct sanctions." by others, including policymakers. ${ }^{88}$

Some liberal philosophers have argued that even if the law can affect moral choices, the state has little or no role in restricting individual choices about the right to marry or divorce or how to raise children. ${ }^{89}$ Many family law scholars, reviewing law and policy trends over the last few decades, have concluded that this liberal tradition, to a large extent, has triumphed. ${ }^{90}$ They claim that devotion to individual rights is the pri-

85. For example, in a 1996 public appearance, President Clinton stated: "You cannot imagine how many women and children are thrown into poverty simply because the responsible parent, usually the father, walks away and leaves them without any money and won't help . . . This is a moral outrage and a social disaster." President William Clinton, Remarks to the Community in Denver (July 22, 1996), in 32 Weekly Comp. Pres. Doc. 1305.

86. The related question of the relative place of religion and government in promoting "family values" is thoughtfully discussed in STEPHEN CARTER, THE CULTURE of DisbelteF: How AMERICAN Law and Polmics Trivialize Reuigious Devotion (1993); see also Stephen Carter. Civility: MaNnERS, Morals, aNd the ETtQuetTe of Democracy (1998).

87. GLENDON, supra note 78, at 10 . Lon Fuller suggests that the difficulty in developing laws that foster morality within families might explain the narrow focus on sexual conduct and adultery. See FULLer, supra note 24, at 40.

88. See Galston, supra note 83 , at 40 .

89. See Jeremy Waldron, John Rawls and the Social Minimum, in LIBERAl RIGHTS: Collected PAPERS 1981-1990, at 250, 268-269 (1993).

90. See, e.g., MitTon C. Regan, JR., FAMILY LaW and the PURsuit of INTIMacy 1-3 (1993) (arguing that the premise of modern family law, "like other liberal institutions, should remain neutral among visions of the good life, intervening only when necessary to prevent one individual from harming another," promotes a vision of the self that is "fundamentally asocial" and undermines the "communal preconditions" for intimacy in family life); Krause, supra note 80, at 125 (acknowledging the need to develop laws that respect the value this country places on parents' right to autonomy and privacy, but finding that "[r]ecent trends of non-intervention, of 'privacy' and 'value neutrality' favor parental autonomy in procreation and child-rearing too decisively"); William E. Nelson, Patriarchy or Inequality: Family Values or Individuality, 70 ST. JOHN's L. REv. 435, 438 (1996) (conclud- 
mary cause of the diminished force of morality as a guiding principle in family law. ${ }^{91}$ As Carl Schneider states:

That tradition [of noninterference in the family] has been reinforced by an ideological development-the increasing displacement of the old republican ideal and the elevation to legal orthodoxy of that dictum from Mill's On Liberty that asserts "that the sole end for which mankind are warranted, individually or collectively, in interfering with the liberty of action of any of their number, is self-protection. That the only purpose for which power can be rightfully exercised over any member of a civilized community, against his will, is to prevent harm to others." 92

This theme-that an emphasis on individualism and non-interference has reduced the role of morality in family policy-is also reflected in the writings of policymakers. William Galston believes that the decline of the two-parent family over the last three decades can be attributed, in part, to the value society places on "individualism, on self-expression, and selfrealization, and on personal choice." 93

Amidst the voices emphasizing the conflict between individual rights and strong families are a few commentators suggesting more fruitful ways of analyzing the shifts in family law over the last three decades. ${ }^{94}$ The paradigm of freedom, autonomy, and individualism versus the common good, shared values, and strong families may no longer advance the discussion. A broader view of morality and a reconception of rights as effective tools for protecting vulnerable family members suggests that a concern for individual rights is compatible with a concern for morality. In an article examining the role of rights in friendships and other close relationships, Michael Meyer suggests that recognizing rights and individual differences can actually strengthen relationships: "Individual moral

ing society's "shared commitment to individualism" has impeded gender equality and other family law reforms); Teitelbaum, supra note 8, at 439 (expressing dissatisfaction with the application of Mill's theory to family law and arguing that "family relationships should be founded on rules and practices we can call good" rather than simply the absence of harm); JoHN WITIE, JR. FROM SACRE. ment to Contract: Marriage, Religion and LaW IN Western TRadTion (1997) (identifying specific strands of hundreds of years of religious and philosophical pronouncements on marriage, which have produced the current model of marriage that is weakened by its focus on individual over community).

91. See supra note 90.

92. Schneider, Moral Discourse, supra note 1, at 1839.

93. Galston, supra note 7 (identifying the shift in American values from sacrifice and selfrestraint to self-expression and personal choice as a trend that has contributed to the increase in divorce); see also JAN DIZARD \& Howard GADLIN, THE MINMMAL FAMILY (1990) (arguing that individual rights and family autonomy represents a moral change that has rendered the traditional family obsolete).

94. See, e.g., Cahn, supra note 1, at 270; Minow, supra note 4, at 260; Rhode \& Minow, supra note 1 , at 198. 
rights provide individuals with a certain secure moral standing. A proper sense of self-worth is not inconsistent with the virtues of friendship. Clearly, habits of self-respect inspired by rights can encourage such virtues among one's friends." 95

Many feminists have rejected a rights-based approach to regulating family law because of its connection to concepts of individual privacy and non-interference, which tend to maintain and support the traditional patriarchal family structure. ${ }^{96}$ Moreover, cultural feminists find rights-talk hostile to the concepts of community and affiliation..$^{97}$

There are, however, a number of feminists and other scholars who believe "careful protection of rights protects friendships and affiliation of many kinds and constructs a morally valuable sort of community." 98 Extending this reasoning from the tightly woven community of friends to the community of family members, one could argue that parents and children who are secure in their rights and responsibilities to one another may have healthier, stronger relationships. A number of commentators have supported the idea that rights have a place in family relationships and that such rights and communitarian values are not mutually exclusive.

In accounting for changes in family policy in recent decades, Martha Minow sees liberty and private ordering as just one of the choices available to decision makers in a given conflict. In other conflicts, decision makers may choose state intervention:

Committed to equality and liberty, driven by legacies of differences and discrimination, our legal system reflects simultaneous devotion to neutrality toward-or

95. Michael J. Meyer, Rights Between Friends, PHIL 467, 474-75 (1992); see also Elizabeth S. Scott, Rehabilitating Liberalism in Modern Divorce Law, 1994 UTAH L. REv. 687, 688-89 (arguing that communitarian values and liberalism are not mutually exclusive).

96. For example, Carol Smart argues that:

[T]he "family" constitutes one instance of the operation of patriarchal relations in the concrete. Indeed the "family" can be identified as a focal point at which a range of oppressive practices meet. It is both an ideological and economic site of oppression which is protected from scrutiny by the very privacy that "family life" celebrates.

Carol Smart. The Ties That Bind: Law, Marriage and the Reproduction of Patriarchal RelaTIONS 10 (1984).

97. See, e.g., Robin West, Jurisprudence and Gender, 55 U. CHL. L. REv. 1, 28 (1998) (summarizing cultural feminism as revolving "not around the axis of autonomy, individuality, justice and rights ... but instead around the axis of intimacy, nurturance, community, responsibility and care").

98. Martha C. Nussbaum, Aristotle, Feminism and Needs for Functioning, 70 TEX. L. REv. 1019, 1027 (1992). See also Milton C. Regan, Jr., Alone Together: Law and the Meanings of MARRIAGE (1999) (arguing that altruism and sharing should coexist with rights and economic justice in marriage); Merle H. Weiner, "Civilizing" the Next Generation: A Response to Civility: Manners, Morals, and the Etiquette of Democracy by Stephen L. Carter, 42 How. LJ. 241, 287-90 (1999). 
better yet, tolerance of - private choices and devotion to officially articulated values ... [B]oth religious and family freedoms protect the autonomy of the Amish who resist a compulsory school law as an incursion on their way of life, and yet neither religious nor family freedoms could shield a parent or guardian from a child labor law applied to forbid a child from distributing religious leaflets on the street or from conviction for child endangerment for withholding medical treatment due to religious belief. 99

Minow also suggests that the idea that laws are ever value-neutral is false. ${ }^{100}$ Each time the government, through its lawmakers, decides to regulate or refrains from regulating, a choice in values is made. ${ }^{101}$ As Minow sees it, "neutrality," in some absolute sense, is not an option; instead, there is the choice between deference to the value of private freedom and the alternative of publicly imposed values. ${ }^{102}$ Minow goes on to challenge policymakers to "articulate a possibility of tolerance and commitment to particular values." 103

Therefore, two overarching points should guide one's analysis of the impact of changes in family law over the last few decades on the moral vision of family law. First, despite the debates about whether law can or should promote morality, the fact is that regulating families is a valueladen enterprise. Building on the classical tradition, contemporary moral philosophy has broadened the meaning of morality in ways that prompt reconsideration of the moral implications of no-fault developments in family law. Even laws that do not explicitly address right and wrong often have a moral dimension. As Martha Minow puts it, no-fault and related developments have "simply shifted the focus from the moral conduct of the parties prior to divorce (who did what to whom) to the moral obligations that should be recognized following divorce (who is responsible to whom, to what extent, and for what duration)." 104 Rethinking what it means to promote moral conduct in family law also means rethinking what constitutes the language of morals. Discourse in laws and decisions that imposes duties and responsibilities on one family member for another is moral discourse.

Second, while deep division exists among the general population, ${ }^{105}$

99. Minow, supra note 4 , at 258.

100. See id. at 258-59.

101. See id.

102. See id.

103. Id. at 261.

104. Rhode \& Minow, supra note 1 , at 198.

105. See generally WOLFE, supra note 23 (identifying the deep divisions on issues of homosexuality and same sex marriage among the American public). 
judges, ${ }^{106}$ and family law scholars, ${ }^{107}$ about the ideal family, there are shared moral principles that support the protection and support of children. ${ }^{108}$ In evaluating whether there has been a decline in moral discourse in family law one must ask whether the law's traditional focus on fault addressed the central moral truths in family law, particularly protection of children. If not, the focus should shift from evaluating the decreased emphasis on fault to exploring the extent to which developments in family law over the last few decades address and promote these central values. The remaining sections of this Article seek to answer these questions.

\section{The "Old” Moral Discourse: Regulating Sexual Conduct}

Despite the broad definition of morality and virtue described in the preceding Section, the code of behavior and the notion of right and wrong in the "fault" era of family law were primarily concerned with prohibiting certain sexual practices. ${ }^{109}$ Constitutional protection for the private sphere of the family developed in cases beginning in the $1920 \mathrm{~s},{ }^{110}$

106. Compare Michael H. v. Gerald D., 491 U.S. 110, 124 n.3 (1989) (Scalia, J., plurality opinion) (defining the family unit accorded traditional respect in our society as the "unitary family," typified by the marital family), with Moore v. City of East Cleveland, 431 U.S. 494, 504 (1977) (holding that "[o]urs is by no means a tradition limited to respect for the bonds uniting the members of the nuclear family").

107. This division is, perhaps, most striking when comparing those scholars urging policies and laws that reinforce the traditional two parent family with those scholars who defend the single parent family model. Compare Lynn D. Wardle, No-Fault Divorce and the Divorce Conundrum, 1991 BYU L. Rev. 79, 135 (1991) (arguing that "we have made a major mistake by not paying greater attention to how our new divorce-on-demand system is affecting an entire generation of children brought up in the poverty of single parent homes"), with NANCY E. DOWD. IN DEFENSE OF SINGLE-PARENI FAMLIES (1997) (arguing that marriage does not support women and may not protect children).

108. See supra notes $73-85$ and accompanying text.

109. June Carbone traces the emphasis on regulating sexual conduct as an element of family policy in this country to "a set of moral codes criminalizing fornication, adultery, and sodomy many of which have been repealed or remain unenforced." Carbone, Child Custody, supra note 79, at 270 (citing Martha albertson Fineman, The Neutered Mother, The Sexual Family, and Other Twentieth Century Tragedies 145-76 (1995)).

110. See generally Cleveland Bd. of Educ. v. LaFleur, 414 U.S. 632 (1974); Stanley v. Illinois, 405 U.S. 645 (1972); Boddie v. Connecticut, 401 U.S. 371 (1971); Griswold v. Connecticut, 381 U.S. 479 (1965); Poe v. Ullman, 367 U.S. 497 (1961); Pierce v. Society of Sisters, 268 U.S. 510 (1925); Meyer v. Nebraska, 262 U.S. 390 (1923). Related cases arising under the First Amendment and the Equal Protection Clause include Wisconsin v. Yoder, 406 U.S. 205 (1972); Prince v. Massachusetts, 321 U.S. 158 (1944); Skinner v. Oklahoma, 316 U.S. 535 (1942); see also Anne C. Daily, Constitutional Privacy and the Just Family, 67 TuL. L. REv. 955 (1993) (reviewing Supreme Court decisions that have developed a right of family privacy while recognizing tradition of state regulation of the family). 
but the notion that the state could regulate family life to promote moral behavior among its members was always firmly embedded. ${ }^{111}$ However, the behavior scrutinized for its morality was primarily focused on sexual conduct. ${ }^{112}$ A dissent by Justice Harlan in a 1961 case upholding a state ban on contraceptive use for married couples reflects the narrow scope of issues viewed as "moral":

[The] inclusion of the category of morality among state concerns indicates that society is not limited in its objects only to the physical well-being of the community, but has traditionally concerned itself with the moral soundness of its people as well. ... The laws regarding marriage which provide both when . . . children are born and brought up, as well as laws forbidding adultery, fornication and homosexual practices which express the negative of the proposition, confining sexuality to lawful marriage, form a pattern so deeply pressed into the substance of our social life that any Constitutional doctrine in this area must build upon that basis. ${ }^{113}$

This Section will provide examples from divorce, custody, and support law of this narrow definition of morality in the fault era, and will evaluate the shortcomings of this approach in promoting moral conduct, particularly with respect to the care and nurturing of children. ${ }^{114}$ Even if this system worked once, it began to break down decades ago. ${ }^{115}$ By the time the sole reliance on fault was discarded in the 1970s, it did not

111. See generally Teitelbaum, supra note 8 (reviewing Carl E. Schneider, Moral Discourse and the Transformation of American Family Law, 83 MicH. L. REv. 1803 (1985) and discussing the role courts have played in regulating moral behavior within the family).

112. See supra note 109 and accompanying text.

113. Poe v. Ullman, 367 U.S. 497, 545-46 (1961) (Harlan, J., dissenting). June Carbone has traced the history of the link between morality and sexual conduct. Marriage, with its common law ideal of the "transcendental" unity of spouses, was an exception to the general hostility towards sexual relationships that existed in this country since its founding. This ideal separated conjugal intercourse from other forms and linked it to a unity that depended on the different, but complementary natures of men and women, and the nature of marriage as a lifelong and monogamous institution. This ideal was important to maintaining the link between sex, procreation and childrearing and was critical to the creation of marriage as a permanent institution necessary to protect vulnerable women, and connect children to family lineages that were an important sense of wealth and identity. The major purpose of family law, then, was to reinforce a set of norms that discouraged divorce and extramarital (both pre-marital and adulterous) conception. It was never intended to manage a system of widespread divorce or to regulate conduct within marriage. The fault law's emphasis on regulation of sexual conduct should therefore, she argues, not be evaluated in the context of current conditions. See Carbone, supra note 51, at 272-75.

114. States adopted no-fault laws at different times beginning about 1967 and continuing throughout the 1980s. Therefore, the cases describing the concepts of fault embodied in divorce, alimony and custody laws are drawn from cases that may have been decided as late as the 1980s. Additionally, because some states still retain concepts of fault in their divorce laws, particularly with respect to divorce grounds, a few cases used to illuminate concepts of fault are even more contemporary.

115. See infra note 124 and accompanying text. 


\section{A. The Meaning of Fault as Grounds for Divorce}

The fault-based system of divorce, established in this country in the mid-nineteenth century, has its roots in religious law because the ecclesiastical courts governed divorce in England. ${ }^{117}$ Under this system a divorce was only granted at the request of an innocent spouse upon proof of a "fault" or offense against the marriage by the other spouse. ${ }^{118}$ This reflected the Anglican religious view that marriage was a "permanent moral bond between husband and wife."119 Carl Schneider describes the ideal of marriage embodied in fault-based divorce as a "life-long mutual responsibility and fidelity from which a spouse could be relieved, roughly speaking, only upon the serious breach of a moral duty by the other spouse." 120

Other commentators have described fault-based divorce as reflecting America's view of marriage as a "contract with God and spouse"121 which conveys a "powerful message about the permanence of marriage and family commitments." 122 This view of the moral underpinning of fault-based divorce law is echoed in nineteenth century Supreme Court case law:

116. See id.

117. See Homer H. Clark, JR. \& Carol Glowinsky, Domestic Relations 6-7 (4th ed. 1990) ("The American colonies, upon their establishment, received many of the English rules concerning marriage, divorce and the status of married women. Of course the colonies never had ecclesiastical courts but these doctrines appeared in legislative enactments and judicial decisions and became part of our civil law.").

Though the Ecclesiastical Law of England is no part of our Common Law . . . that part of the jurisdication of the Ecclesiastical Courts relating to annulment of marriage and divorce was given by law to our Courts, it is reasonable to believe that we should follow the princi-

ples and precedents of the Ecclesiastical Courts in the administration of our law . . .

S. v. S., 29 A.2d 325, 326 (Del. Super. Ct. 1942).

118. See Adriaen M. Morse, Jr., Comment, Fault: A Viable Means of Re-Injecting Responsibility in Marital Relations, 30 U. RuCH. L. REv. 605, 607 (1996).

119. Christopher Price, Comment, Finding Fault with Irish Divorce Law, 19 LoY. L.A. INT'L \& COMP. L.J. 669, 683 (1997) (analyzing the American experiences with both fault and no-fault systems of divorce and recommending the Irish adopt the fault-based system in implementing Ireland's 1995 referendum on divorce).

120. Schneider, Moral Discourse, supra note 1, at 1809.

121. Morse, supra note 118 , at 606.

122. Wardle, supra note 1 , at 750 . Wardle goes on to emphasize that the fault-based system underscored permanence in marriage because " '(c)ommitment is the moral virtue." "Id. at 751 (quoting Allan BloOM, THe Closing of the AMERICAN MiNd 201 (1987)). 
[W] hile marriage is often termed by text writers and in decisions of courts a civil contract ... it is something more than a mere contract. The consent of the parties is of course essential to its existence, but when the contract to marry is executed by the marriage, a relation between the parties is created which they cannot change. Other contracts may be modified, restricted, or enlarged, or entirely released upon the consent of the parties. Not so with marriage. The relation once formed, the law steps in and holds the parties to various obligations and liabilities. It is an institution, in the maintenance of which in its purity the public is deeply interested, for it is the foundation of the family and of society, without which there would be neither civilization nor progress. ${ }^{123}$

While many commentators acknowledge weaknesses in the application of the fault system in practice, ${ }^{124}$ reliance on fault grounds for divorce is almost uniformly described as expressing society's moral belief that marriage is a lifetime commitment to one's spouse with all the emotional and economic obligations associated with that commitment. ${ }^{125}$

Both the articulation in the law and application in practice of faultbased divorce did little to promote this idealized view of marriage. First, the concept of "fault" has always been a very narrow one. Monogamy is the principle form of commitment envisioned under the traditional fault grounds. Other important commitments such as providing financially for wives during marriage or after divorce or treating wives and children respectfully and without violence were not addressed or emphasized in the fault system. A brief review of the evolution and history of the faultbased grounds for divorce reveals how narrow the concept of marital misconduct was in that system.

Because the English ecclesiastical courts, under the doctrines of the Roman Catholic Church and, later, under the Church of England, viewed marriage as a permanent bond, there was no absolute divorce under the common law. ${ }^{126}$ The first inroad into state-sanctioned divorce was a late

123. Maynard v. Hill, 125 U.S. 190, 210-211 (1888). This view has continued well into the twentieth century. See, e.g., Griswold v. Connecticut, 381 U.S. 479, 486 (1965).

124. Even those who condemn or criticize the "no-fault" access to divorce acknowledge the failure of fault grounds to promote commitment to marriage. It is generally accepted that by the time no-fault grounds were being adopted in some states in the 1960 s, the fault system had resulted in the widespread use of perjured testimony and had encouraged acrimony between divorcing couples by requiring fault or blame to lie with one party. See, e.g., GLENDON, supra note 78, at 79 ("The [fault] system had degenerated into a formal recitation of perjured testimony, leaving acrimony in its wake ...."); Wardle, supra note 107, at 79, 135 (critiquing no-fault divorce, but acknowledging the negative impact of "hostile litigation [and] deceit in legal processes" in fault-era divorces). But see, e.g., MAX Rheinstein, MARRIAGe Stability, DivorCE, AND the LAW 258 (1972) (arguing that the dual system of fault-based divorce on the books and divorce by collusion and mutual consent in practice was a "compromise" that satisfied both conservatives and liberals).

125. See supra notes 119-23 and accompanying text.

126. Of course, the Roman Catholic Church could grant annulments, and did so freely during 
seventeenth-century Parliamentary Act permitting divorce $a$ vinculo ${ }^{127}$ on grounds of adultery. ${ }^{128}$ Homer Clark and Carol Glowinsky describe this "avenue of escape from marriage" for "the richest and most powerful people in Britain":

This was the divorce by special Parliamentary Act, given only for adultery. . . Not only was this kind of divorce confined to the rich, it was also largely the prerogative of men, only four being granted to wives during one hundred and fifty years. There are some indications that the virtual absence of practicable legal methods for terminating marriages led large segments of society to adopt non-legal methods for this purpose, that is, to separate and contract subsequent marriages without benefit of divorce. ${ }^{129}$

Adultery remained the only ground for divorce in England even after divorce jurisdiction was transferred from the ecclesiastical courts to the civil court system in $1857 .{ }^{130}$ It was not until 1937 that English law added other fault-based grounds for divorce, the most commonly invoked being cruelty and desertion. ${ }^{131}$ Although American law has always allowed divorce more freely than English law, the development of divorce law in this country reflects its British and ecclesiastical roots, particularly in its emphasis on adultery as the most serious offense against the marriage. June Carbone has traced the historical development of American family law, noting the existence of eighteenth century legislation prescribing the death penalty for "adulterie" and "sodomie":"132 "Early American family law was marked by a clear identification of sexual mo-

this time. See Homer H. Clark, JR. The Law of Domestic Relations in the UntTed States $125-$ 26 (2d ed. 1988).

127. "a vinculo matrimonii: Lat. From the bond of matrimony. A term descriptive of a kind of divorce, which effects a complete dissolution of the marriage contract." BLACK'S LAW DICTIONARY 136 (6th ed. 1990). Prior to the Church's exclusive jurisdiction over marriage and divorce in England, Anglo-Saxon law allowed divorce by consent of the spouses or for the wife's aduitery or desertion. See CLARK, supra note 126 , at 406 . English common law also permitted a divorce $a$ mensa et thoro, or divorce from bed and board. This was a legal separation on certain enumerated fault grounds, but neither party could remarty. See PETER N. SWISHER ET AL, FAMILY LAW: CASES, Materlals and Problems 715 (1990).

128. See CLARK \& GLOWINSKY, supra note 117 , at 6 .

129. Id.

130. See The Statutes of the United Kingdom of Great Britain and Ireland 20 Victoria, $1857 \mathrm{v}$. 97. Divorce and Matrimony causes 20 and 21 Vict. c85, described in Margaret $\mathrm{K}$. Woodhouse, The Marriage and Divorce Bill of 1857, 3 AM. J. LEGAL HIST. 260, 273 (1959).

131. Matrimonial Causes Act 1937, 1 Edw. 8 \& 1 Geo. 6 ch. 57 . English divorce law now includes no-fault grounds and is set forth in Matrimonial Causes Act 1973, ch. 18 (Eng.).

132. Carbone, supra note 51, at 273 (citing Michael Grossberg, Governing the HeARTH:

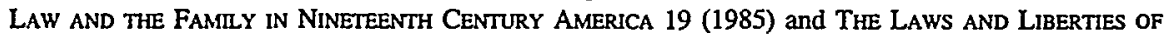
MASSACHUSETTS 5 (Max Farrand ed., 1929)). 
rality as fundamental to the importance of marriage, and was religious, if not necessarily sectarian, in origin." 133 While there were variations in the speed with which divorce became available by statute in different geographic regions, ${ }^{134}$ adultery was consistently included as one or, sometimes the only, fault ground. ${ }^{135}$

Indeed, until 1966, the only ground for divorce in New York was adultery. ${ }^{136}$ Even when many states added the additional grounds of cruelty and desertion, adultery was the most commonly used ground. ${ }^{137}$ It was a popular and reliable ground for a couple of reasons. First, in some states, adultery was the only ground that did not require the parties to separate for a year or more before filing for divorce. ${ }^{138}$ Additionally, while corroboration of adultery may have presented some proof problems, the relatively clear and straightforward definition of adultery ${ }^{139}$

133. Id.

134. Those areas settled by Protestants-primarily New England-had general divorce statutes from the time of settlement. In the middle Atlantic and Southern states, the areas most influenced by Catholicism and the Church of England, the colonies did not permit divorce except by legislative act throughout most of the eighteenth and nineteenth centuries. See ClaRK \& GlowiNSKY, supra note 117 , at 7 .

135. Discussing the state of marriage in the nineteenth century, David Hoffman noted that "the policy of most countries ... has been to allow no other ground for the actual dissolution of the [marriage] contract, than adultery." DAvid HoFman, LeGAL Outuines 150 (1836).

136. See N.Y. DoM. REL LAW $\$ 170$ (McKinney 1988) (adding cruelty, abandonment, and excessive prison confinement, which became effective Sept. 1, 1967).

137. See Laura Bradford, The Counterrevolution: A Critique of Recent Proposals to Reform No-Fault Divorce Laws, 49 STAN. L. REv. 607, 610 (1997). By the time no-fault grounds for divorce were widely adopted in the 1970 s and 1980 s, cruelty had become the most popular ground for divorce. See ClARK, supra note 126, at 506.

138. See, e.g., MD. Code ANn. FAM. LAW § 7-103(a) (1991).

139. " 'Adultery' is generally defined as sexual intercourse by either spouse with someone other than their spouse." JOHN DEWITT GREGORY ET AL. UNDERSTANDING FAMILY LAW 209 (1993). However, there is some variation in the way courts have defined the term. See, e.g., Menge v. Menge, 491 So. 2d 700, 702 (La. Ct. App. 1986) (holding that wife's admission of having had oral sex but not coitus fell under definition of adultery); Bales v. Hack, 509 N.E.2d 95, 98 (Ohio Ct. App. 1986) (stating that although homosexuality is not a specifically enumerated ground for divorce, it could constitute adultery or extreme cruelty). The potential variation on the definition of adultery has been the subject of renewed interest as the media has examined the sexual conduct of various public officials. See, e.g., Walter Kirn, When Sex Is Not Really Having Sex, Time, Feb. 2, 1998, at 30; Nancy Kruh, No Foolin': That's What Adultery Is, Dallas Morning NEws, Jan. 27, 1998, at IC; Tony Pugh, Definition of Adultery, Infidelity Debated, Times-PICAYUNE, Jan. 25, 1998, at A26; Jason Vest, Robb's Unadulterated Opinion: A Rousing Debate on the Infamous Fidelity Factor, WASH. Post, Apr. 1, 1994, at D1.

Of course, corroboration of adultery did present proof problems. See, e.g., Everett v. Everett, 345 So. 2d 586, 590 (La. Ct. App. 1977) ("Courts are a bit more sophisticated today and infer that people do what comes naturally when they have the opportunity."); Westervelt v. Westervelt, 258 N.E.2d 98, 99 (N.Y. 1970) (holding evidence of spouse's cohabitation with another insufficient to prove adultery); Seemann v. Seemann, 355 S.E.2d 884 (Va. 1987) (holding that evidence that defend- 
may have made it easier to prove than other fault grounds, most of which permitted trial judges wide discretion in defining them. ${ }^{140}$

The emphasis in statutes and other legal commentary devoted to adultery resulted in a preoccupation with sexual misconduct as the primary measure of morality in marriage. Other immoral behavior, such as physical and verbal abuse or failure to provide adequate economic support to a dependent spouse or children, were sanctioned in a system in which sexual misconduct was the only indication of fault within a marriage. The value of this focus on sexual conduct as a way to evaluate or promote moral behavior was further undercut by the double standard some commentators have observed in the application of adultery statutes. ${ }^{141}$

The other two grounds for divorce that were most widely used in the fault era were cruelty ${ }^{142}$ and desertion. ${ }^{143}$ While both of these grounds permitted courts the opportunity to sanction conduct in marriage that went beyond sexual morality, they were of limited value in promoting moral conduct. The historical context in which these grounds were developed and the broad discretion permitted judges in applying these grounds permitted the development of dual standards for husbands and wives. ${ }^{144}$ For example, while cruelty was initially developed as a ground for divorce to assist women with abusive husbands, ${ }^{145}$ it was applied in an era

ant wife had spent ten nights in room with adult male was insufficient to prove adultery when wife testified that she had not slept with the man due to her strong religious beliefs).

140. Terms like cruelty and constructive desertion are subject to wide interpretation by trial judges applying them in divorce cases. See infra note 465.

141. See Frances Olsen, The Family and the Market: A Study of Ideology and Legal Reform, 96 HARV. L. REv. 1497, 1533 n.139 (1983) ("[S]trict divorce laws have historically operated more harshly upon women than upon men. For example, in many states a woman's single act of adultery constituted grounds for divorce but a man's adultery would not unless it were repeated or flagrant.").

142. One definition of cruelty is that it "occurs only when there is bodily harm or a reasonable apprehension of bodily harm." CLARK, supra note 126 , at 507 . In the states where cruelty is not available (MD, NC, VA) or is strictly construed (DE, $P A)$, the concept of constructive desertion evolved to fill the gap in situations where the spouse's cruelty forces the other spouse to leave the marital home. See, e.g., Sackman v. Sackman, 203 A.2d 903 (Md. 1964).

143. Willfulness is a requirement in desertion statutes. See, e.g., AlasKa Stat. § 25.24.050 (Michie 1998); Idaho CoDE § 32-603 (1996); Miss. Code ANN. § 93-5-1 (1994); 23 PA. Cons. STAT. ANN. \& 3301(a)(1) (West 1991). Most statutes require that the desertion continue over a period of time, one year being the most common. See CLARK, supra note 126, at 501.

144. See Nelson, supra note 90 , at 517 (finding a double standard in New York courts' definition of cruelty).

145. See Nan Oppenlander, The Evolution of Law and Wife Abuse, 3 LAW \& PoL. Q. 382, 388-89, 393-94 (1981); Nancy F. Cott, Divorce and the Changing Status of Women in EighteenthCentury Massachusettes, 33 WM. \& MARY Q. 586, 588-89 (1976) (arguing that the courts interpreted fault requirements early in the 18th century in ways that prevented women from obtaining divorces 
when a husband was entitled to use some force to discipline his wife. ${ }^{146}$ Courts often required a pattern of substantial physical abuse where cruelty grounds were invoked against a husband. In one case, evidence that a husband had hit his wife with his fist within the first two months of their marriage was not sufficient to establish cruelty. ${ }^{147}$ In another case, the wife alleged that her husband had "committed physical cruelty on her person" and that she was "afraid to live with [him] for fear that he [would] commit further and additional harm and injury [to her]." 148 The complaint was dismissed because only actual violence of a degree attended with "danger to life or health" constituted cruelty. ${ }^{149}$ The courts were so tolerant of violence by a husband that they found one man justified in striking his wife after he had found her sitting on the lap of another man and kissing him. ${ }^{150}$ Some courts also held that if the wife had reason to know that her future husband was abusive before the marriage, her prior knowledge barred her later use of cruelty as grounds for divorce. ${ }^{151}$

On the other hand, relatively minor transgressions by a wife have been interpreted as cruelty justifying a husband's action for divorce. For example, divorces have been granted on cruelty grounds based on the wife's persistent nagging, ${ }^{152}$ her "denial" of the husband's "marital rights" 153 or a demand that he use contraceptives. ${ }^{154}$ In contrast, a husband's lack of sexual interest in his wife ${ }^{155}$ or other failure to have sexual

except for the most reprehensible male conduct).

146. See Sir Wlllam Blackstone, Commentaries on the Laws of England 445 (Thomas M. Cooley ed., 3d ed. 1884) (stating that a husband may, by force, keep his wife within the bounds of duty). See also James Schouler, Marriage, Divorce, Separation and Domestic Relations, $\S 1574$ (6th ed 1921). For a discussion of the recent controversy over whether the law ever explicitly adopted a "rule of thumb" permitting a man to beat his wife so long as the rod was no thicker than his thumb, see infra note 328 .

147. See Glantz v. Glantz, 310 P.2d 23 (Cal. Dist. Ct. App. 1957).

148. McDowell v. McDowell, 223 So. 2d 277, 279 (Ala. 1969).

149. Id; see also Capps v. Capps, 219 S.E.2d 898 (Va. 1975) (holding that a single act of physical violence was not enough to entitle wife to divorce on ground of cruelty).

150. See Nilsen v. Nilsen, 183 N.Y.S.2d 210, 212 (Sup. Ct. 1959).

151. See Williamson v. Williamson, 204 S.W.2d 785, 787 (Ark. 1947).

152. See McGann v. McGann, 186 P.2d 424, 426 (Cal. Dist. Ct. App. 1947) (granting divorce where plaintiff's wife "was cold toward him, nagged him, wrote him whining letters while overseas, turned her back on him while in bed, attempted to regulate his life and refused to permit him to go bowling with his father....").

153. Di Croce v. Di Croce, 209 N.Y.S.2d 624, 627 (Sup. Ct. 1961).

154. See Barretta v. Barretta, 46 N.Y.S.2d 261, 263 (Sup. Ct. 1944). But see Dahnken v. Dahnken, 161 N.Y.S.2d 539, 540 (Sup. Ct. 1957) (holding that wife's belief that she had valid reason to leave home for husband's use of contraception did not constitute abandonment).

155. See McClinton v. McClinton, 200 N.Y.S.2d 987, 989 (Sup. Ct. 1960). 
relations did not constitute cruelty. ${ }^{156}$

The husband's right at common law to determine where both his wife and children could live, ${ }^{157}$ codified in some states, ${ }^{158}$ also led to an early dual standard in desertion cases. Thus, a failure of a wife to follow her husband when he moved, except in the most egregious circumstances, would give rise to a cause of action against her for divorce on grounds of desertion. ${ }^{159}$ The husband had no corresponding duty to defer to a wife's decision to move; if a wife left the marital home, she would be guilty of desertion. ${ }^{160}$

The enactment of the Married Women's Property Acts ${ }^{161}$ and the ex-

156. See Shepetin v. Shepetin, 229 N.Y.S.2d 457, 459 (App. Div. 1962). Of course, given the absence of no-fault grounds during this period, husbands and wives often colluded to create grounds for divorce. Thus, in some of these cases, the other party may not have opposed the charge of cruelty. Additionally, the need to circumvent the system may have contributed to the inconsistencies. See J. Herbie Difonzo, Beneath the Fault line: The Popular and legal Culture of Divorce in TWENTIETH-CENTURY AMERICA 55 (1997). See also discussion infra at Section III C(1)(a).

157. The husband's right to control both his domicile and that of his wife is based on the "unity of person" doctrine of marriage, which deprived married women of an independent legal existence. CLARK, supra note 126, at 286-88; see also Motykowski v. Motykowski, 282 N.E.2d 458, 461 (Ill. App. Ct. 1972); Lewis v. Lewis, 284 A.2d 21, 23 (Md. Ct. Spec. App. 1971); Cavallo v. Cavallo, 359 N.Y.S.2d 628, 629-30 (N.Y. App. Div. 1974); Santarsiero v. Santarsiero, 331 A.2d 868, 869 (Pa. Super. Ct. 1974).

158. See, e.g., CAL. Crv. CODE $\S 5101$ (repealed 1975); LA. Civ. Code ANN. art. 120 (repealed 1985); OHI REv. CODE ANN. § 3103.02 (repealed 1974).

159. See, e.g., Roby v. Roby, 77 P. 213, 215 (Idaho 1904) (holding that husband was not guilty of desertion where the husband established a home in a desolate mining region and his wife refused to follow him on the ground that it was not a fit place to live because it was disagreeable five months of the year, when most of the travel was on snowshoes, and there were no schools, churches or theaters in the locality); Crosby v. Crosby, 434 So. 2d 162 (La. Ct. App. 1983); Bennett v. Bennett, 79 A.2d 513, 515 (Md. 1951) (emphasizing the well-established doctrine that the husband, being the head of the family and legally responsible for its support, has the right to choose and establish the domicile for himself and his wife, and when he provides a new domicile, his wife's refusal to follow him constitutes desertion, unless the change is plainly unreasonable). This case was superceded by MD. CoNST. art. 46, Maryland's version of the Equal Rights Amendment. See Blount v. Boston, 718 A.2d 1111 n.5 (Md. 1998)).

160. See, e.g., Towson v. Towson, 258 F. 517, 518-19 (D.C. Cir. 1919) (holding that a wife who left her husband because of cruelty, taking their minor child with her, was not entitled to separate maintenance or custody of the child when she was unable to sustain her claim of cruelty and thus had deserted her husband without just cause), overruled in part by Barlett v. Barlett, 221 F.2d 508 (D.C. Cir. 1954); McGrath v. Gimler, 60 N.Y.S.2d 622, 624 (N.Y. App. Div. 1946) (holding that a father who left New York to take up residence in Wyoming had the right to custody of the child over the mother who deserted the father by refusing to follow and live with him in Wyoming).

161.

[U]nder the Married Women's Acts, in force in most if not all states, the unity of the spouses is severed, and each is a separate legal personality in so far as the disabilities of the wife are abolished; but such acts are to be construed as not otherwise impairing the unity of the spouses. ... The law continues to recognize that unity with respect to certain rights, duties, and obligations arising from the marriage and constituting its object. These Married Wo- 
pansion of concepts of equal protection in gender discrimination cases ${ }^{162}$ have resulted in more evenhanded applications of cruelty and desertion statutes. ${ }^{163}$ However, the statutory language adopted in most states is expansive enough to continue to allow trial judges broad discretion in their application. ${ }^{164}$ This discretion leads to both unpredictability and inconsistency in application. ${ }^{165}$ It also permits judges to apply their own standards of behavior which, given the composition of the state judiciary, still means the male perspective will dominate. ${ }^{166}$

Finally, a review of reported decisions on cruelty and desertion grounds reveals the same preoccupation with sexual morality as the pri-

men's Enabling Acts do not purport to operate upon the family relations, or to take from the husband, his marital rights, except as they pertain to property.

26 AM. JUR. Husband and Wife § 3 (1940) (footnotes omitted); see also Richard H. Chused, Married Women's Property Law: 1800-1850, 71 GEO. LJ. 1359 (1983).

162. See, e.g., Orr v. Orr, 440 U.S. 268, 278-83 (1979); Craig v. Boren, 429 U.S. 190 (1976); Frontiero v. Richardson, 411 U.S. 677 (1973); Reed v. Reed, 404 U.S. 71 (1971).

163. The dual standard in desertion cases resulted, in part, from the husband's right to determine the family's domicile. This common law inability of married women to establish a separate domicile was eroded in many states by the adoption of the Married Women's Property Act because these statutes severed the common law "unity of spouses." See supra note 161. In addition, the principle of derivative domicile for married women was successfully litigated in the 1970s on equal protection grounds. See, e.g., Samuel v. University of Pittsburgh, 375 F. Supp. 1119 (W.D. Pa. 1974), rev'd in part, 538 F.2d 991 (3d Cir. 1968).

164. For statutory language on cruelty, see, for example, MAss. GEN. LAws ANN. ch. 208, § 1 (West 1998) ("cruel and abusive treatment"); Miss. CoDE ANN. § 93-5-1 (1994) ("habitual cruel and inhuman treatment"); N.H. REV. STAT. ANN. § $458: 7$ (1992) ("extreme cruelty"); N.J. STAT. ANN. § 2A:34-2 (West 1987) ("extreme cruelty"); N.M. STAT. ANN. § 40-4-1 (Michie 1994) ("cruel and inhuman treatment"); N.Y. DoM. REL LAW § 170 (McKinney 1988) ("cruel and inhuman treatment ... endanger[ing] the physical or mental well being of the plaintiff"); N.D. CENT. CODE § 14-05-03 (1997) ("[e]xtreme cruelty"); OHо Rev. CODE ANN. \$ 3105.01 (Anderson 1994) ("extreme cruelty"); OKI. Stat. ANN. tit. 43, § 101 (West 1990) ("[e]xtreme cruelty"); 23 Pa. Cons. Stat. ANN. $\S 3301$ (West 1991) ("cruel and barbarous treatment endanger[ing] . . . life or health"); R.I. GEN. LAwS § 15-5-2 (1996) ("extreme cruelty"); S.C. CODE ANN. § 20-3-10 (Law Co-op. 1985) ("Ip]hysical cruelty"); S.D. Codified LAWs § 25-4-2 (Michie 1992) ("[e]xtreme cruelty"); Vt. Stat. ANN, tit. 15, § 551 (1989) ("intolerable severity"); VA. CODE ANN. § 20-91 (Michie 1995) ("cruelty"); W. VA. CODE, § 48-2-4 (1998) ("cruel or inhuman treatment").

For statutory language on desertion, see, for example, ALA. CODE § 30-2-1(a) (1989); ALASKA Stat. § 25.24 .050 (1998); ConN. Gen. Stat. ANN. § 46b-40 (West 1995); GA. Code ANN. § 19-5-3 (1991); 750 ILl. CoMp. Stat. ANn. 5/401(2)(1) (West 1993); MD. CODE ANN., FAM. LAW \& 7-102 (1991); Mass. Gen. Laws ANN. ch. 208, § 1 (West 1998); NJ. Stat. ANn. § 2A:34-2 (West 1987); N.Y. Dom. ReL. LAW $\S 170$ (McKinney 1988); OhIo REv. Code ANN. § 3105.01 (Anderson 1994); 23 Pa. Cons. Stat. Ann. 33301 (West 1991); Tenn. Code AnN. § 36-4-101 (1996); Vt. Stat. AnN. tit. 15, § 291 (1989); VA. CODE ANN. \$ 20-91 (Michie 1995).

165. Of course the indeterminancy of the cruelty ground also contributed to its popularity in the fault era when many divorces were obtained by collusion and perjury. See DIFonzo, supra note 156 , at 51-56.

166. See Women in tHe LaW: A LoOK AT THE Numbers 31 (American Bar Association, Dec. 1995) (finding that in 1991, 7\% of federal court judges and $9 \%$ of state court judges were women). 
mary way of evaluating conduct in marriage. ${ }^{167}$ Boasting of affairs with other women, ${ }^{168}$ a husband's insistence on excessive, unnatural, or otherwise unreasonable sexual intercourse, ${ }^{169}$ transvestitism or transsexualism, ${ }^{170}$ refusal to engage in sexual intercourse, ${ }^{171}$ homosexuality, ${ }^{172}$ and a wife's desire to use contraception during sexual relations ${ }^{173}$ have all been considered cruelty under various state statutes.

Further, because both cruelty and desertion require that the couple has ceased cohabitation, ${ }^{174}$ a significant number of litigated cases on desertion have focused on whether sexual relations have occurred within a marriage. ${ }^{175}$ These cases focus on whether a spouse has refused sexual relations, ${ }^{176}$ whether the refusal of sexual relations amounts to desertion, ${ }^{177}$ and whether the refusal to have sexual relations is justified. ${ }^{178}$

The inquiry into misconduct through the fault-based divorce grounds has provided only a very limited opportunity for legislators and judges to engage in moral discourse about the meaning of commitment in mar-

167. See Kristine Cordier Karnezis, Annotation, Fault As Consideration in Alimony, Spousal Support, or Property Division Awards Pursuant to No-Fault Divorce, 86 A.L.R. 3d 1116 (1978).

168. See Smith v. Smith, 30 Cal. Rptr. 250 (1963); see also Diehl v. Diehl, 149 A.2d 133 (Pa. Super. Ct. 1959); R.P. Davis, Annotation, Insistence on Sex Relations as Cruelty or Indignity Constituting Ground for Divorce, 88 A.L.R. 2d 553 (1963).

169. See Thomason v. Thomason, 332 S.W.2d 148 (Tex. Civ. App. 1959).

170. See Steinke v. Steinke, 357 A.2d 674 (Pa. Super. Ct. 1975).

171. See Hinkle v. Hinkle, 74 S.E.2d 657 (Ga. 1953); Mante v. Mante, 309 N.Y.S.2d 944 (N.Y. App. Div. 1970).

172. See H. v. H., 157 A.2d 721 (N.J. Super. Ct. App. Div. 1959).

173. See Forbes v. Forbes, 1 W.L.R. 531 (1955).

174. See ALASKa STAT. $\$ 25.24 .050$ (Michie 1998) (willful desertion for one year); ARK. CodE ANN. § 9-12-301 (Michie 1998) (willful desertion of 18 months separation); CONN. GEN. STAT. ANN. § 46b-40 (West 1995) (willful desertion for one year); GA. CODE ANN. § 19-5-3 (1991) (willful desertion for one year); MD. CODE ANN., FAM. LAW \& 7-103 (1991) (desertion for 12 months without interruption); MASS. GEN. LAWS ch. 208, § 1 (1998) (utter desertion for one year); N.H. Rev. STAT. ANN. $\S 458: 7$ (1992) (unexplained absence for two years; joining religious group believing the relation of husband wife unlawful and refusal to cohabit for six months); N.J. STAT. ANN. § 2A:34-2 (West 1987) (cruelty for three months; desertion for 12 months); N.Y. DoM. REL. LAW $\S 170$ (McKinney 1988) (abandonment for one or more years); OKLA. STAT. ANN. tit. 43, § 101 (West 1990) (abandonment/desertion for one year); 23 PA. CoNs. STAT. ANN. $\$ 3301$ (West 1991) (desertion for one or more years); R.I. GEN. LAwS \$ 15-5-2 (1996) (desertion for five years); S.C. CODE ANN. § 203-10 (Law Co-op. 1985) (desertion for five years); TENN. CODE ANN. § 36-4-101 (1996) (desertion for one year or absent state for two years); UTAH CODE ANN. § 30-3-1 (1998) (willful desertion for more than one year); Vr. STAT. ANN. tit. 15, § 551 (1989) (desertion for seven years); W. VA. CoDE $\S 48-2-4$ (1998) (abandonment or desertion for six months).

175. See ClARK, supra note 126, at 504 (noting that the majority of litigated cases on desertion focus on whether cessation of cohabitation has occurred).

176. See id. at 504 n.47; Fortman v. Fortman, 243 A.2d 517, 520-21 (Md. 1968).

177. See ClaRK, supra note 126 , at 504 n.48.

178. See, e.g., Hodges v. Hodges, 131 A.2d 703, 704-05 (Md. 1957). 
riage. This body of law tells married couples that sexual indiscretions can have serious consequences-i.e., provide a legal ground for ending a marriage. However, the messages about conduct outside the area of sexual relations are inconsistent and unpredictable and include the destructive message that treating one's spouse with respect and freedom from physical abuse may not be obligations the law envisions in marriage.

Fault-based divorce decisions also endorse a double standard for men and women when judges evaluate the behavior of husbands and wives differently as they apply divorce grounds. The expense and delay experienced by both parties to a divorce when fault has to be litigated hurts families trying to cope with the trauma of family breakup. These costs can rise to the level of a moral issue when the party seeking the divorce does so to protect herself and her children from violence and protection is delayed by the expense and length of court proceedings. ${ }^{179}$

\section{B. Alimony Law in the Fault Era}

The "no-fault revolution"180 also resulted in a shift in the law's approach to alimony or spousal support. This change was marked primarily by a dimunition of the role of fault in alimony decisions and is viewed by many commentators as part of the "tendency toward diminished moral discourse" 181 in alimony.

Prior to the 1970 s, alimony was awarded to wives only following a legal separation or divorce. ${ }^{182}$ Although there did not appear to be any single justification set forth in the early statutes authorizing alimony, both need and fault were the primary justifications for early awards of alimony. ${ }^{183}$ English alimony law placed greater emphasis on the need to

179. Battered women are at greatest risk of abuse when attempting to separate from their abusive partners. Among victims of violence committed by an intimate, women separated from their husbands were three times more likely to be victimized than divorced women and twenty-five times more likely to be victimized than married women. See Ronet Bachman \& Linda E. Salzman, Violence Against Women: Estimates from the Redesigned Survey, U.S. Dept. of Justice (Aug. 1995).

180. For a description of the term "no-fault revolution," see supra note 6.

181. Schneider, Moral Discourse, supra note 1, at 1809; see also Carl E. Schneider, Rethinking Alimony: Marital Decisions and Moral Discourse, 1991 BYU L. Rev. 197, 233-57 (1991).

182. See 1 Whliam Blackstone, Commentaries *189. In 1979, the United States Supreme Court decided Orr v. Orr, 440 U.S. 268 (1979), holding that the Alabama statute authorizing alimony to be imposed only upon husbands and in favor of wives violated the Equal Protection Clause. Prior to 1979 , only a few states permitted alimony to be granted to husbands. See, e.g., CaL. Fam. CODE $\S 4330$ (West 1994); MASS. GEN LAwS ch. 208, $\$ 34$ (1998).

183. Alimony, unknown at common law, is a creature of statute. See Chester G. Vernier \& John B. Hurlbut, The Historical Background of Alimony Law and Its Present Statutory Structure, 6 LAW \& Contemp. Probs. 197, 201 (1939). 
support the wife as a basis for alimony because the award was made in the context of a legal separation in which the parties would remain married and the husband had a continuing obligation to support his wife. ${ }^{184}$ However, in this country, where alimony was awarded upon absolute divorce, the law placed greater emphasis on alimony's punishment and reward functions. ${ }^{185}$ Characterizing the early justification for alimony under American law, one commentator notes that "[a]limony was based largely on fault and was only available to innocent wives whose husbands had caused the marriage to fail." 186 Additionally, alimony tended to be awarded for life when it was ordered because it was not directly tied to the wife's economic need. ${ }^{187}$

This view of alimony in the fault era has been interpreted as promoting moral discourse because it required courts to focus on "innocent" 188 or "guilty" conduct. ${ }^{189}$ Wives were regularly denied alimony when courts interpreted their actions as conduct that "broke up the marriage" 190 or made them "guilty" parties. ${ }^{191}$ The presumption favoring a lifetime award of alimony has also been interpreted as promoting moral discourse because it recognized that "each spouse assumes lifelong responsibility for the other." 192

An examination of the way alimony laws were crafted and applied reveals the limits of fault-based alimony laws' ability to promote moral-

184. Under English common law, wives surrendered their property rights at marriage and had no ability to support themselves while married. 2 BURNS, ECCLESIASTICAI LAW 450-51 (1781).

185. See Gregory et al,, supra note 139, at 243; Chester G. Vernier. 2 American Famill LAW 259 (1932).

186. GREGORY ET AL, supra note 139, at 243. But see Dayton v. Dayton, 161 S.W.2d 618 (Ky. 1942); Rader v. Rader, 126 So. 2d 189 (La. App. 1961); Wolfe v. Wolfe, 124 N.E.2d 485 (Ohio Com. Pl. 1954); Bray v. Landergren, 172 S.E. 252 (Va. 1934).

187. See CLARK, supra note 126 , at 650 .

188. See Dayton v. Dayton, 161 S.W.2d 618 (Ky. 1942); Rader v. Rader, 126 So. 2d 189 (La. App. 1961); Wolfe v. Wolfe, 124 N.E.2d 485 (Ohio Com. Pl. 1954); Bray v. Landergren, 172 S.E.2S2 (Va. 1934).

189. The guilt of either spouse is relevant. See, e.g., Lewis v. Lewis, 151 S.W.2d 998 (Ark. 1941); Gusman v. Gusman, 39 N.E. 918 (Ind. 1895); Poppe v. Poppe, 52 N.E.2d 506 (Ind. App. 1944). But see Bonanno v. Bonanno, 72 A.2d 318 (N.J. 1950); O'Neill v. O'Neill, 11 A.2d 128 (N.J. Ch. 1939); Miles v. Miles, 202 P.2d 485 (Or. 1949); Cecil v. Cecil, 19 S.E.2d 64 (Va. 1942).

190. See Stumpf v. Stumpf, 179 A.2d 893, 896 (Md. 1962) (holding that wife, who refused to reconcile with allegedly alcoholic husband until he agreed to let her resume control of their finances, had effectively deserted her husband).

191. See Mathews v. Mathews, 459 So. $2 d$ 546, 549-50 (La. Ct. App. 1984) (reiterating that a party need only establish by circumstantial evidence the reasonable conclusion that adultery has been committed and denying wife permanent alimony on the trial court's finding that she was "guilty of adultery").

192. Schneider, Moral Discourse, supra note 1, at 1810. 
ity. First, the fact that alimony was unavailable to husbands in most jurisdictions undermined its role in promoting mutual responsibility and commitment in marriage. Indeed, the cases from this era reveal the hardship created under this rule. ${ }^{193}$ The fact that wives who were not found to be "innocent" were denied alimony also worked to exclude many deserving wives. ${ }^{194}$

The nature of the task of evaluating marital misconduct also increased the likelihood of harsh or unfair results. Findings of fact about guilt or innocence are subjective and imprecise; two judges hearing the same case could easily reach two different conclusions on whether a wife was innocent or a husband guilty. ${ }^{195}$ For example, in a case where a wife left her husband after he physically and mentally abused her, one judge might find that the husband constructively deserted the wife and therefore award her alimony. ${ }^{196}$ On similar facts, another judge might interpret the wife's actions in leaving an abusive husband as actual desertion on her part and therefore deny her alimony as the "guilty party." 197

Additionally, the tendency of the law is to place inappropriate weight on sexual misconduct, specifically adultery, but not enough weight on other kinds of misconduct such as physically or mentally abusing one's spouse ${ }^{198}$ had implications for alimony as well. Thus, a wife who committed one act of adultery in a thirty year marriage during which she devoted herself to raising children and supporting the husband's career would be left with no support after marriage. ${ }^{199}$ In an era when most women were economically dependent, a wife who experienced abuse by her husband might have to stay in a violent marriage or risk loss of support because the abuse may not be included under a par-

193. See, e.g., Davis v. Davis, 189 So. 2d 158, 159-60 (Ala. 1966) (holding that the husband should not be awarded the parties' jointly owned home even though he received custody of their child).

194. See GreGory ET AL, supra note 139, at 243. But see, e.g., Margaret F. Brinig \& June Carbone, The Reliance Interest in Marriage and Divorce, 62 TuL L. REv. 855 (1988) (reviewing nineteenth and twentieth century cases on alimony and finding substantial variation on the issue of whether a "guilty" spouse could collect alimony).

195. See Carl E. Schneider, Discretion, Rules and Law: Child Custody and the UMDA's BestInterest Standard, 89 MicH. L. Rev. 2215, 2250 (1991) (discussing drawbacks of judicial discretion).

196. See Bartlett v. Bartlett, 221 F.2d 508 (D.C. Cir. 1954).

197. See, e.g., Towson v. Towson, 258 F. 517, 518-19 (D.C. Cir. 1919) (holding that a wife who left her husband because of cruelty was not entitled to alimony where she was unable to sustain her claim of cruelty and thus had deserted her husband without just cause).

198. See supra notes $147-51$ and accompanying text.

199. In many states, if a divorce was granted to the husband based on the wife's adultery or some other conduct giving rise to fault-based grounds, the wife would be barred from receiving alimony. See supra notes 186, 190-91 and accompanying text. 
ticular judge's concept of cruelty or constructive desertion. ${ }^{200}$ Thus, while the statutes and decisionmakers used language which purported to punish misconduct and reward virtue in marriage, often the application of these laws did not accomplish those goals.

Finally, the message of marriage as a lifetime commitment was further undercut by the infrequency and low levels of alimony awarded under this system. Fewer than $16 \%$ of divorces occurring between 1887 and 1922 included provisions for permanent alimony. ${ }^{201}$ Statistics in the 1960s and 1970s reveal a similar pattern in which alimony was awarded in less than $20 \%$ of divorce cases. ${ }^{202}$ Post 1980 award data show a similar pattern. ${ }^{203}$

When alimony was awarded, the amounts were low. ${ }^{204}$ The Census

200. See Bradford, supra note 137, at 631-632; Martha Heller, Note, Should Breaking-Up Be Harder to Do?: The Ramifications a Return to Fault-Based Divorce Would Have upon Domestic Violence, 4 VA. J. Soc. PoL'Y \& L. 263, 272 (1996) (arguing that requiring women to prove the misconduct of violent husbands in support proceedings "would deter women from leaving dangerous relationships"). But see Margaret F. Brinig \& Steven M. Crafton, Marriage and Opportunism, $23 \mathrm{~J}$. LEGAL STUD. 869, 869 (1994) ("[T]ncreased abuse and other undesirable behavior is a natural consequence of the fact that in some states the marriage contract cannot be enforced."); Wardle, supra note 1, at 741 (critiquing the "no-fault divorce culture" and suggesting a link between no-fault divorce and violence).

201. See Paul H. Jacobson, American Marriage and Divorce 127 (1959). A nationwide sample of divorce decrees revealed that $9.3 \%$ of divorces included provisions for permanent alimony from 1887-1906; in 1916, the percentage was 15.4 and in 1922, alimony was awarded in $14.7 \%$ of cases. See id.

202. See WertzMan, supra note 6, at 162-68 (indicating that between 1968 and 1972, the percentage of cases in which alimony was denied went from $20 \%$ to $15 \%$ in California cases; this percentage had increased to 17\% by 1977); see also Robert E. McGraw et al., A Case Study in Divorce Law Reform and Its Aftermath, 20 J. FAM. L. 443, 473 (1981-82) (indicating that alimony awards in Cuyahoga County, Ohio, declined from $20 \%$ of cases in 1965 to $16 \%$ in 1978).

203. See Bureau of the Census, U.S. Dep't of Commerce, Current Population Reports, Series P-23, No. 152, Child Support AND Alimony: 1985 (1987). According to a 1986 United States Census Bureau survey, fewer than 15 percent of all women who had ever been divorced or were currently separated had obtained an agreement or court order to receive alimony. See id. For other studies of the percentage of women awarded alimony at divorce, see ALASKA WOMEN'S COM-

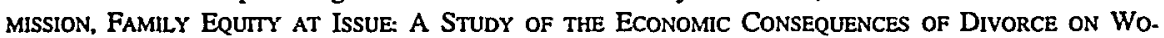
MEN AND CHILDREN 17 (Oct. 1987) (10\% in Alaska); WertzMAN, supra note 6, at 167 (17\% in California); Rosalyn B. Bell, Alimony and the Financially Dependent Spouse in Montgomery County, Maryland, 22 FAM. L.Q. 225, 267 (1988) (38\% among contested adjudications and 11.5\% among uncontested cases in Montgomery County, Maryland); McGraw et al., supra note 202, at 473 (16\% in Cuyahoga County, Ohio); James B. McLindon, Separate But Unequal: The Economic Disaster of Divorce for Women and Children, 21 FAM. L.Q. 351, 362 (1987) (30\% received more than $\$ 1$ per year alimony in New Haven County, Connecticut); Barbara R. Rowe \& Alice M. Morrow, The Economic Consequences of Divorce in Oregon After Ten or More Years of Marriage, 24 WILLAMETtE L. Rev. 463, 476 (1988) (28\% in Oregon); Heather Ruth Wishik, Economics of Divorce: An Exploratory Study, 20 FAM. L.Q. 79, 85 (1986) (7\% in Vermont).

204. See Bureau of the Census, U.S. Dept. of Commerce, Current Population Reports, 
Bureau reported that the average amount of alimony received by women in 1978 was $\$ 2,850^{205}$ The figure went to $\$ 3,733$ in 1985 , a decrease when adjustments for inflation were calculated. ${ }^{206}$ The use of broad discretionary standards for setting alimony permitted judges a wide range in setting alimony and resulted in low awards. ${ }^{207}$ Decisions and coromentary from the era also reflect negative stereotypes about women that may have influenced both the scarcity and the meagerness of awards. ${ }^{208}$

All of these circumstances - exclusion of needy husbands, exclusion of financially needy women who were not deemed "innocent," the imprecision of findings of guilt and innocence, and the reluctance to award any or adequate alimony in a vast majority of cases-undermined the moral power of alimony in fault-based divorce and hurt women, and, particularly, children. ${ }^{209}$ Despite the language in statutes, which suggested spouses would be accountable for misconduct in marriage and that virtuous wives could count on a lifetime of support, the application of these laws did little to reinforce those messages. On the contrary, lawyers counseling husbands considering divorce in the fault era could assure clients that they could avoid responsibility for dependent spouses by urging

Series P-23 No. 112, ChIld Support AND Alimony: 1978, at 9 (1981). This report was the first report in which the Census Bureau reported data from a survey specifically designed to obtain data on child support and alimony. See id. at 1.

205. See id.

206. See BUREAU of tHE CENSUS, supra note 203, at 7. For other studies of amounts of alimony awarded at divorce see ALASKA WOMEN's COMMISSION, supra note 203 (median $\$ 500 / \mathrm{month}$ ); WenZMAN, supra note 6, at 171 (median \$210/month); Bell, supra note 203, at 286 (mean monthly award ranged from $\$ 366.67$ for marriages of 6-10 years to $\$ 650.88$ for marriages over 15 years).

207. See Jana B. Singer, Divorce Reform and Gender Justice, 67 N.C. L. REv. 1103, 1106-09 (1989).

208.

Alimony was never intended to assure a perpetual state of secured indolence. It should not be suffered to convert a host of physically and mentally competent young women into an army of alimony drones, who neither toil nor spin, and become a drain on society and a menace to themselves.

Samuel H. Hofstadter \& Shirley R. Levittan, Alimony-A Reformulation, 7 J. FAM. L. 51,55 (1967). We do not construe the marriage status, once achieved, as conferring on the former wife of a ship-wrecked marriage the right to live a life of veritable ease with no effort and little incentive on her part to apply such talent as she may possess to making her own way.

Kahn v. Kahn, 78 So. $2 d$ 367, 368 (Fla. 1955); see also Turner v. Turner, 385 A.2d 1280, 1282 (N.J. Super. Ct. Ch. Div. 1978).

209. Studies have documented the decline in standard of living of custodial parents-predominantly mothers-and children after divorce. See, e.g., DiANE DODSON \& JOAN ENTMACHER. WOMEN's Legal Defense Fund, Report Card on State Child Support Guidelines 32 tbl. 4-E (1994); Elea. nor E. Maccoby et al., Dividing the Child: Soclal and Legal Dilemmas of Custody 126-30, 257-62 (1992) (identifying a decline in standard of living experienced by custodial parents and children after divorce). 
an interpretation of facts that shifted or shared blame for the disintegration of the marriage.

The husband could be further reassured that, even if the judge found the husband "guilty" and the wife "innocent," the chances of being ordered to pay substantial alimony were small. For similar reasons, that same lawyer, counseling an "innocent" wife, could do little to assure that woman that her commitment to her marriage would result in financial support following divorce. Therefore, the moral force of alimony law in the fault era was very weak.

\section{Custody in the Fault Era}

According to some commentators, modern custody law is another area of family law in which the relevance of moral judgments has been deemphasized in the no-fault era. ${ }^{210}$ However, an examination of custody law in the fault era reveals a similar preoccupation with sexual conduct as the primary focus of moral inquiry. As a result of this preoccupation, discussions of right and wrong in custody cases were narrowly conceived in the fault-era and often did not focus on behavior that was most relevant to parental fitness and protection of children.

A particularly striking example of fault-era courts' tendency to view sexual conduct as the sole measure of morality is found in a 1962 New York custody decision. ${ }^{211}$ In that case, the court approved a trial court's judgment denying custody to a mother based on her extramarital affair and described the court's role in enforcing morality:

It therefore has devolved upon the courts to establish the moral standards to be followed by persons to whom is entrusted the care and custody of children. And never has there been a greater need for the courts to maintain a high level of moral conduct than exists today. This court intends to give more than lip service to the principle that the fabric of our society is composed of the family unit and when the family unit is damaged, the fabric of society suffers. Our courts will continue to insist upon a high level of moral conduct ... a and will never succumb to the 'Hollywood' type of morality so popular today . . . . 212

The emphasis on sexual conduct in fault-era custody cases may be grounded in the historical tendency to stereotype and idealize women in custody law. ${ }^{213}$ Maternal fitness in custody cases was evaluated against

210. See Singer, supra note 1, at 1528 (citing Carol S. Bruch, Forms of Exclusion in Child Custody Law, 7 Ethology \& Sociobiology 339, 341-42 (1986)).

211. See In re Anonymous, 238 N.Y.S.2d 422, 423 (N.Y. Fam. Ct. 1962).

212. Id.

213. This discussion is based, in part, on Jane C. Murphy, Legal Images of Motherhood: Con- 
the stereotype of the ideal mother who was married, stayed at home, and was, most importantly, both heterosexual and monogamous. ${ }^{214}$

Through the early nineteenth century in this country, fathers almost invariably were awarded custody of their children upon divorce or separation. ${ }^{215}$ Consistent with women's general loss of legal status and power upon marriage, ${ }^{216}$ mothers had neither rights nor access to their children if they did not live with the father. ${ }^{217}$ As Blackstone wrote, "[A] mother, as such, is entitled to no power, but only to reverence and respect." $218 \mathrm{~A}$ maternal, or "tender years," presumption had replaced the paternal preference by the middle of the twentieth century. ${ }^{219}$ The presumption provided that unless mothers were unfit, they should have custody of their children, particularly those under age five. ${ }^{220}$ This presumption was grounded in the view that women's natural disposition toward nurturing made them the preferred caretakers. ${ }^{221}$

Even under a system in which the maternal presumption was the rule in all fifty states, courts generally deprived the mother of custody if she was believed to be promiscuous. ${ }^{222}$ Reviewing the state of custody

flicting Definitions from Welfare "Reform," Family, and Criminal Law, 83 CORNELL L. REv. 688, 693-696 (1998).

214. Mothers had neither the legal nor the economic means to raise their children unless they were married to the fathers. The state regarded children as the father's property, subject to his control both during the marriage and after its dissolution. See Roscoe Pound, Individual Interests in the Domestic Relations, 14 MiCH. L. Rev. 177, 181-82 (1916).

215. See Grossberg, supra note 132, at 235; Suzanne Ramos. The Complete Book of Child Custody 32 (1979). For an examination of custody law in an earlier period of history see MARY ann Mason, From Father's Property to ChILdRen's Rughts: The History of ChIld Custody in THE UNITED STATES 1-47 (1994) (examining the treatment of children during colonial times as economic assets with "custody" granted through relationships established in indenture contracts or apprenticeships).

216. See WOMEN AND THE LAW § 3A.02[1]-[2] (Carol H. Lefcourt \& Jane Campbell Moriarty eds., 1996).

217. Mothers had neither the legal nor the economic means to raise their children unless they were married to the fathers. The state regarded children as the father's property, subject to his control both during the marriage and after its dissolution. See Pound, supra note 214, at 181-82 (1916).

218. BLACKSTONE, supra note 146 , at 441.

219. See Katherine Hunt Federle, Looking for Rights in All the Wrong Places: Resolving Custody Disputes in Divorce Proceedings, 15 CARDozo L. Rev. 1523, 1536 (1994). Others have described the matemal preference as taking root much earlier, between the mid-19th century and the 1920s. See MASON, supra note 215, at 118.

220. See ClaRK, supra note 126, at 799 (indicating that, while few courts define "tender years," the "presumption would clearly apply to a child under five years").

221. See Rena K. Uviller, Fathers' Rights and Feminism: The Maternal Presumption Revisited, 1 HARv. WOMEN's LJ. 107, 114 (1978).

222. See Carl A. Weinman, The Trial Judge Awards Custody, 10 LAW \& Contemp. Prob. 720, 731 (1944) (concluding that generally, custody will not be awarded to a parent who has been "guilty" of adultery because it is "immoral conduct"); see also Robert J. Bregman, Custody 
law in 1967, Homer Clark noted that the most common cases involving the "morals of the parties" involved a wife who had committed adultery and that "other forms of immorality are rarely given much discussion." 223 Even twenty years later, he found "[p]arental conduct raising questions of sexual morality has produced more custody litigation than any other types of conduct." 224 Thus, discussions of morality in custody cases often arise in the context of one parent seeking to change or obtain custody based on the sexual practices of their divorced or separated spouse. ${ }^{225}$ These cases are characterized by the courts' assumption that cohabitation or adultery renders a parent morally unfit for custody. ${ }^{226}$

Custody cases reviewing the sexual conduct of a parent are also marked by a tendency to apply a dual standard when evaluating the "moral fitness" of a mother as compared to a father. ${ }^{227}$ The most typical cases involve attempts to control the sexual behavior of a divorced or separated mother seeking to gain or maintain custody. ${ }^{228}$ Courts have held that the mother's cohabitation outside of marriage is itself harmful to the children and warrants state intervention either through a change in cus-

Awards: Standards Used When the Mother Has Been Guilty of Adultery or Alcoholism, 2 FAM. L.Q. 384, 387 (1968).

223. ClARK, supra note 126, at 586.

224. Id., at 803 . Clark notes that this preoccupation with sexual morality in custody cases has continued in some states in the no-fault era. See id. ("Notwithstanding contemporary changes in sexual mores [sic] sexual morality still generates strong emotions in the minds of judges which are reflected in their judgments either expressly or under the surface.").

225. See, e.g., Beasley v. Beasley, 160 So. $2 \mathrm{~d} 863,865$ (Ala. 1964) (finding that while nonmarital sexual conduct "does not, in and of itself, serve as an absolute bar" to giving custody to the offending parent, nevertheless, a finding of adultery on the part of one parent constitutes an "adjudication of [that parent's] relative unfitness to have custody"); Taylor v. Taylor, 309 P.2d 508, 509 (Cal. Dist. Ct. App. 1957) (finding "that a mother who has taken her children into an adulterous home ... has thereby shown her unfitness for custody"); Parker v. Parker, 158 A.2d 607, 610 (Md. 1960) (depriving an adulterous mother of custody despite her "confession of error and avowal of repentance"); Wilson v. Wilson, 590 P.2d 1136, 1139 (Mont. 1979) (finding, on balance, that the children in question would be better off with their father, rather than their aduiterous mother, even though he would have to employ child care); Morrissey v. Morrissey, 154 N.W.2d 66, 67 (Neb. 1967) ("Where a wife is found . . . guilty of adultery, she is an unfit person as a matter of law to have the care and custody of her minor child. . ..").

226. In one of the most frequently cited "morality" custody cases, the Supreme Court of Illinois held that custody could be changed on the father's showing that the mother and children were living with her boyfriend, though there was no showing that this arrangement was harmful to the children. See Jarrett v. Jarrett, 400 N.E.2d 421, 424-26 (Ill. 1979). While the court made reference to "the mental and emotional health of the children" it focused upon "the moral hazards" from cohabitation. See id.

227. See WoMEN AND tHE LAW, supra note 216 , at $\S 6.05[2]$.

228. See Murphy, supra note 213, at 199. 
tody ${ }^{229}$ or the imposition of restrictions on the mother's behavior as a condition to her maintaining custody. ${ }^{230}$ Evidence demonstrating similar paternal extramarital conduct often does not trigger the same punitive response against fathers. ${ }^{231}$

The second category of custody and visitation cases in which courts have traditionally engaged in explicit discussion of "morality" is cases involving gay and lesbian parents. 232 Until the 1980s, few homosexual parents were successful in custody cases. ${ }^{233}$ Similar to cohabitation and adultery cases, the language in these decisions focused on general concerns about "immoral" and "illicit" relationships rather than specific harm to the children involved. ${ }^{234}$

Courts in the fault-era consistently labeled both mothers and fathers actively engaged in homosexual relationships as poor moral examples for

229. See In re Marriage of Thompson \& Thompson, 449 N.E.2d 88, 93 (Ill. 1983) (distinguishing Jarrett v. Jarrett, 400 N.E.2d 421 (IIl. 1979), and granting custody to father who had committed adultery and cohabited with a girlfriend and his children); Melancon v. Bergeron, 598 So. 2d $694,697,699$ (La. Ct. App. 1992) (finding that granting mother physical custody of the children was an abuse of discretion because the mother had lived in "open concubinage" with her boyfriend for over three years, with no intention of getting married, while the father had remarried and could provide a stable environment); Brown v. Brown, 237 S.E.2d 89, 91-92 (Va. 1977) (affirming the trial court's finding that, solely by reason of her adulterous cohabitation, the mother was unfit to be a custodial parent).

230. See, e.g., Parrillo v. Parrillo, 554 A.2d 1043, 1045 (R.I. 1989) (finding that the court could prohibit a wife from spending the night with cohabitant in her house while her children were present).

231. See, e.g., Simmons v. Simmons, 576 P.2d 589, 591-93 (Kan. 1978) (awarding custody to the father because, among other reasons, the mother's fiancee had spent the night in her home, even though the father lived with his girlfriend in a hotel room and had allowed his lover to stay there while the children were present); Flournoy v. Flournoy, 392 So. 2d 1096, 1098-99 (La. Ct. App. 1980) (awarding custody to the father even though both the father and mother engaged in adulterous relations, reasoning that the father's affair was more "discreet" than the mother's); see also Deborah L. Rhode, SPEAKING of SeX: The Denial of Gender INeQualtry (1997) (fault system in custody hurts mothers because courts are generally harsher to women than men in cases of sexual misconduct).

232. See, e.g., Ira Mark Ellman et al., Family Law: Cases, Text, Problems 636-38 (3d ed. 1998) (summarizing and discussing cases and commentary involving custody and visitation disputes based upon sexual conduct of homosexual parents).

233. Twenty years ago, New York courts expressed the view that homosexual relationships were considered "clandestine deviate conduct." In re Jane B., 380 N.Y.S.2d 848, 854, 860 (Sup. Ct. 1976).

234. See, e.g., Chaffin v. Frye, 45 Cal. App. 3d 39, 45 (Ct. App. 1975) (holding that residence in a homosexual household is detrimental to children and contrary to their best interests); Towend v. Towend, No. 639, 1976 Ohio App. LEXIS 6193, at*8-10 (Ohio Ct. App. Sept. 30, 1976) (concluding trial court's preoccupation with the sexual techniques of lesbians was relevant to the direct adverse effect upon children of homosexual activity). But see Nadler v. Superior Ct., $255 \mathrm{Cal}$. App. 2d 523, 525 (Ct. App. 1967) (holding that it is the duty of the trial court to exercise its discretion as to how the welfare of the child will be affected by a parent's homosexuality). 
their children. ${ }^{235}$ Until recently, judges deprived gay and lesbian parents of custody, and in some cases visitation, despite evidence that children might be hurt by being deprived of a parent's care ${ }^{236}$ and that gay parents are as capable of competent and loving care as heterosexual parents. ${ }^{237}$ Thus, the discussion of morals in these cases did little to protect children. As one commentator explained, the arguments against granting custody to homosexual parents are limited to the ideas that "if gay parents have custody, they will perform sex acts in front of the children; if gay parents have custody, the children will be harmed because of the immoral environment."238

The focus of moral discourse in the fault-era was on regulating sexual conduct within marriage. Litigants' right to get a divorce, financial support, or access to their children was largely dependent on having engaged in sexual conduct consistent with trial judges' codes of behavior. The courts gave less protection or attention to dependent members of families created outside of marriage, families experiencing domestic violence, or children in need of support.

\section{The New Moral Discourse in Family Law}

Beginning in the 1970s, courts and legislatures began to implement a series of changes in family law that reduced the role of fault and, consequently, the role of sexual misconduct in deciding who should be granted a divorce. While fault based grounds for divorce continued to exist in most states even in the no-fault era, ${ }^{239}$ the adoption of no-fault in all fifty states by 1985 meant that the option of obtaining a divorce by consent without collusion and perjury was available throughout the country. ${ }^{240}$

235. See N.K.M. v. L.E.M., 606 S.W.2d 179, 186 (Mo. Ct. App. 1980); Jacobson v. Jacobson, 314 N.W.2d 78, 81 (N.D. 1981); M.J.P. v. J.G.P., 640 P.2d 966, 963-69 (Okla. 1982); Constant A. v. Paul C.A., 496 A.2d 1, 5 (Pa. Super. Ct. 1985); Roe v. Roe, 324 S.E.2d 691, 692-94 (Va. 1985). Gay parents' visitation rights were limited in J.L.P. (H.) v. D.J.P., 643 S.W.2d 865, 872 (Mo. App. Ct. 1982) and in Roberts v. Roberts, 489 N.E.2d 1067, 1070 (Ohio Ct. App. 1985). Some more recent decisions have required a demonstrated nexus between harm to the child and the parent's sexual orientation. See infra note 459 and accompanying text.

236. See Bezio v. Patenaude, 410 N.E.2d 1207 (Mass. 1980).

237. See id. at 1216.

238. Rhonda R. Rivera, Queer Law: Sexual Orientation Law in the Mid-Eighties, 11 U. DAYTON L. REv. 275, 329 (1986) (summarizing case law and commentary from the 1970s and 1980s).

239. See Ira Mark Ellman, The Place of Fault in a Modern Divorce Law, 28 ARE. ST. LJ. 773,816 (1996).

240. See Judith areen, Cases and Materials on Domestic Relations 75 (Supp. 1995). 
Following the spread of no-fault grounds for divorce, a number of other changes occurred in family law that shifted the emphasis in family law from punishing adults for sexual infidelity to protecting children's welfare. Although the no-fault revolution's first changes dealt with divorce grounds, no-fault also diminished the role of sexual misconduct in deciding the terms of custody and visitation decisions. In its place, developments in custody law refined the best interest standard to focus on factors that more directly bear on children's well-being.

Simultaneously, other developments in family law during the last three decades have increased both the debate about who can marry and, to some extent, the procedural requirements that encourage couples to reflect on the meaning of commitment prior to marriage. The behavior of family members in ongoing families has also been subject to greater regulation when courts and legislatures reject principles of family autonomy in favor of protecting women and children from family violence. Developments in the law during the last three decades have also increased legal protections for those largely left out of the moral vision of the fault era, financially dependent unmarried cohabitants and children born outside of marriage. Finally, the move in the late 1980s from a broad discretionary standard for setting child support to fixed formulae represents an important step in protecting the economic well-being of children.

\section{A. Access to Marriage}

Over the last century, the regulation of access to marriage has been marked by a steady decline in state interference. ${ }^{241}$ Reviewing the changes in regulation of marriage formation in this country and other Western countries from 1800 to the mid 1980s, Mary Ann Glendon characterized the change as follows:

The picture is one of many small changes, unremarkable in themselves, but together signaling a major transition in the way modern legal systems intersect with marriage behavior.

Viewed in their historical context, the apparently trifling changes . . . are the culmination of a long series of events that, beginning around 1800 , gradually freed individuals from most constraints on their ability to marry or on their choice of marriage partner. ${ }^{242}$

241. See Mary ann Glendon, The Transformation of Famly law: State, law, and Fam. ILY IN THE UNITED STATES AND WESTERN EUROPE 35-36 (1989) [hereinafter GLENDON, TRANSFoRMATION]; GLENDON, supra note 78, at 63-64.

242. Glendon. TRANSFORMATION, supra note 241 , at 35 . The history of regulation of marriage in this country for African-Americans is quite different. Until the 1860 s, because Black men and wo- 
Noting both a declining public health necessity and a growing recognition of a constitutionally-based right to marry, Glendon found that the only remaining restrictions to marriage relate to age, polygamy, and incest, and that even in these areas, many marriage impediments "lack teeth." 243

It is only within the last decade that family law has begun to reexamine the meaning of marriage and the law's role in it. This renewed interest in the meaning of marriage has resulted in legislative debate in both state legislatures ${ }^{244}$ and Congress ${ }^{245}$ about moral issues surrounding the decision to marry. Family law scholars have also devoted increased attention to the religious and moral underpinnings of marriage. ${ }^{246}$

\section{Who May Marry: Same Sex Marriage}

In 1967 , the United States Supreme Court decided Loving v. Virginia, ${ }^{247}$ holding that Virginia's ban on interracial marriages violated the equal protection and due process clauses of the Fourteenth Amendment. ${ }^{248}$ Loving has been viewed as both an example of the law's attempt to further moral behavior and as the beginning of a retreat from regulation of who may marry. ${ }^{249}$ The moral message of Loving - that all people should be treated as equals with dignity and respect-was a strong one. ${ }^{250}$

men were considered slaves and had no legal rights, they were not permitted to marry. See JEAN KoH Peters, Representing Children in Child Protective Proceedings: Ethical and Practical Dimen. sioNs 243-45 (1997) (describing separate system of American family law for Blacks that "actively thwarted their attempts to live together in conventional family households").

243. Glendon. TRANSFormation, supra note 241 , at 35.

244. See infra notes $275-77,309$ and accompanying text.

245. See infra notes $263-67$ and accompanying text.

246. See infra notes $249,271,279-80$ and accompanying text.

247. 388 U.S. 1 (1967).

248. See id. at 12.

249. See Robert A. Destro, Introduction, Symposium, Law and the Politics of Marriage: Loving v. Virginia Afier Thirty Years, 47 CATH. U. L. REv. 1207, 1215-17 (1998).

250. See Loving, 388 U.S. at 12; see also Robert F. Drinan, The Loving Decision and the Freedom to Marry, 29 Onо ST. L.J. 358 (1968). Given the practices and values of the time, however, Loving's moral message of respect and dignity might be categorized as an attempt to legislate the morality of aspiration rather than reflecting values that existed in the United States in the late 1960s. At the time of Loving, seventeen states had laws that prohibited interracial sexual relations and interracial marriage. See Walter Wadlington, The Loving Case: Virginia's Anti-Miscegenation Statute in Historical Perspective, 52 VA. L. REv. 1189, 1190 n.8 (1966). In 1968, the year that interracial marriage became legal across the United States, a Gallup poll found that some 72 percent of Americans still disapproved of such marriages, even if they were prepared to tolerate them. Although public attitudes about interracial marriage have changed since 1967, discrimination against such 
However, given its emphasis on autonomy and privacy, Loving has also been interpreted as marking the beginning of a significant retreat from state regulation of who may marry. ${ }^{251}$ In the thirty years following Loving, access to marriage has been an area to which legislators and family law scholars have paid very little attention. ${ }^{252}$ Recently, however, in a reaction to legislative and judicial consideration of proposals to legalize same sex marriage, moral discourse about the meaning of marriage has emerged as a central aspect of the legal and policy debate on the issue. $^{253}$

While the constitutionality of state laws denying the right for same sex couples to marry had been challenged from time to time in the past few decades, ${ }^{254}$ the wide ranging debate about the meaning of marriage did not begin until 1993.25s In that year, the Hawaii Supreme Court became the first state court in the nation to hold that its laws banning same sex marriage were subject to "strict scrutiny" under the Hawaiian constitution's equal protection clause. ${ }^{256}$ The court further held that the law is

couples continues in the 1990s. See Paul C. Rosenblatt et al, Multiracial Couples: Black and WHITE VOICES 6 (1995).

251. See Walter O. Weyrauch et al., Cases and Materials in Family law: legal Con. CEPTS AND CHANGING HUMAN RELATIONSHIPS 489 (1994) (interpreting Loving as, among other things, signaling "the increased autonomy of the parties [to the marriage] and the decline of state involvement in marriage"); see also Margaret F. Brinig, Equality and Marriage, Presentation at Law and the Politics of Marriage (Nov. 19-21, 1997) (arguing that Loving "sets the tone" for the Supreme Court's family law jurisprudence, which emphasizes autonomy and individual rights); Robert $F$. Drinan, American Laws Regulating the Formation of the Marriage Contract, 383 ANNALS AM. ACAD. PoL. \& Soc. SCL 48, 49 (1969) (characterizing Loving as reflecting a "profound consensus" in the United States that the law should say "as little as possible about who should marry whom").

252. In the intervening years, the Supreme Court also invalidated a state law precluding the issuance of marriage licenses to people with unpaid child support obligations. See Zablocki v. Redhail, 434 U.S. 374 (1978). The Court also struck down a state regulation prohibiting inmate marriages in the state's prisons. See Tumer v. Safley, 482 U.S. 78 (1987). Both decisions rested on the Loving Court's holding that the "right to marry" is a fundamental due process right. See id. at 95; Zablocki, 434 U.S. at 386.

253. Universal prohibitions against same sex marriage are an exception (along with prohibitions on multiple and incestuous marriages) to modern American marriage law's avoidance of definitively restricting a person's ability to marry. See GlENDON, TRANSFORMATION, supra note 241, at 4950. Same sex prohibitions exist because they are outside the scope of marriage. See id. at 49.

254. See, e.g., Dean v. District of Columbia, 653 A.2d 307 (D.C. 1995); Baker v. Nelson, 191 N.W.2d 185 (Minn. 1971). For a comprehensive list of judicial and attomey general opinions on the legality of same sex marriage prior to the Hawaii case, see WILLIAM N. ESKRIDGE, JR. \& NAN D. HUNTER, SEXUALITY, GENDER, AND THE LAW 803 n.f (1997). Although the plaintiffs in many of these cases raised constitutional challenges, most courts failed to analyze the constitutional issue holding that the definition of marriage precludes same sex unions. See id. at 803-04.

255. The debate began with a decision to deny a marriage license to two women that culminated in Baehr v. Lewin, 852 P.2d 44 (Haw. 1993).

256. See id. at 47. The Hawaii Supreme Court granted the state's subsequent motion for clari- 
presumed to be unconstitutional unless the state can show that the statute's sex based classification is justified by compelling interests and is narrowly drawn to avoid unnecessary abridgment of the couple's rights. ${ }^{257}$

Baehr v. Lewin set off a broad debate about the meaning of marriage and commitment throughout the country. Much of the discussion at the federal level occurred in the context of the congressional debate of the Defense of Marriage Act (DOMA), ${ }^{258}$ introduced in May, 1996. DOMA provides a federal definition for the terms "marriage" and "spouse" (for purposes of federal benefits) by specifying that marriage is a union of a man and a woman, and that the term "spouse refers only to a person of the opposite sex."259 DOMA also specifies that states are not required to give effect to same sex marriages under the Full Faith and Credit Clause. ${ }^{260}$ DOMA purportedly rests on Congress's power (in Art. IV, §1) to implement the Full Faith and Credit Clause. ${ }^{261}$

While some of the debate about the legislation focused on strictly legal questions about constitutional or conflict of laws issues that were raised by the legislation, ${ }^{262}$ much of it can be characterized as moral discourse focused on the law's role in promoting love and commitment and defining families. Consider the following exchange between Congressman Barney Frank and Congressman Henry Hyde during the May, 1996 debate in the House of Representatives on the legislation:

MR. FRANK: We are talking here about a desperate search for a political issue. ${ }^{263}$

fication and advised that the state had the burden, on remand, to show that the statute furthered a compelling interest. See id. at 74. The trial court then ruled that the state had failed to sustain its burden of proof and enjoined the state from denying an application for a marriage license solely because the applicants are of the same sex. See Baehr v. Miike, No. 91-1394, 1996 WL 694235 at *16 (Haw. Cir. Ct. Dec. 3, 1996). The case has been appealed to the Hawaii Supreme Court. In April 1997, the Hawaii legislature voted to place on the November 1998 ballot a constitutional amendment that would restrict marriage to persons of the opposite sex. The proposed amendment recognizes limited benefits (inheritance rights, the right to sue for wrongful death, insurance and state pension benefits) for gay and lesbian couples. The state filed a motion seeking to delay any decision until after the balloting, but the high court denied the motion, clearing the way for oral argument.

257. See Baehr, 852 P.2d at 67.

258. Defense of Marriage Act, Pub. L. No. 104-199, 110 Stat. 2419 (1996).

259. Id.

260. See id.

261. See id.

262. See, e.g., The Defense of Marriage Act: Hearing on S. 1740 Before the Senate Committee on the Judiciary, 104th Cong. $42-48$ (1996) (statement of Cass R. Sunstein, Professor of Jurisprudence, University of Chicago).

263. Andrew Sullivan, Same-Sex Marriage: Pro and Con 225 (1997) (quoting from the House debate on the Defense of Marriage Act). 
MR. HYDE: Political! . . . There is no political gain. But there is a moral issue. . . Nobody wants to talk about it. We are forced to talk about it by the courts. . . .

Don't assume that people are doing this for political profit. People don't think that the traditional marriage ought to be demeaned or trivialized by same-sex unions. If two men want to love each other, go right ahead. If you want to solemnize your love affair by some ceremony, create one. But don't take marriage, which for centuries has been a union between man and woman, and certainly is in this country, and try to say that what you're doing is American. ${ }^{264}$

MR. FRANK: I guess my problem is this. There are plenty of people here who have had marriages that have meant a great deal to them. I salute that. I don't for a minute understand how it demeans, and I would ask the gentleman to explain that to me. The gentleman's marriage, the marriages of other members here are based on a deep love, a bond between two people ... How does anything I do in which I express my feelings toward another demean the powerful bond of love and emotion and respect of two other people?265

When the debate moved to the Senate, legislators on both sides invoked morality in their debate:

SENATOR GRAMM: So here are the issues in very simple fashion. No. 1 , is there anything unique about the traditional family? For every moment of recorded history, we have said yes. In every major religion in history ... . governments have recognized the traditional family as the foundation of prosperity and happiness, and in democratic societies, as the foundation of freedom. Human beings have always given traditional marriage a special sanction ... . Are we so wise today that we are ready to reject five thousand years of recorded history? ? $^{266}$

SENATOR RobB: . . . Mr. President, I believe it is time for those of us who are not homosexual to join the fight. A basic respect for human dignity-which gives us the strength to reject racial, gender and religious intolerance-dictates that in America we also eliminate discrimination against homosexuals. I believe that ending this discrimination is the last frontier in the ultimate fight for civil and human rights. . . .

Ultimately, Mr. President, immorality flows from immoral choices. But if homosexuality is an inalienable characteristic, which cannot be altered by counseling or willpower, then moral objections to gay marriages do not appear to differ significantly from moral objections to interracial marriages. ${ }^{267}$

\section{The bill was passed by Congress in September, $1996^{268}$ and signed by President Clinton amidst great controversy. ${ }^{269}$}

264. Id.

265. Id.

266. 142 CoNG. REC. S10105-06 (daily ed. Sept. 10, 1996) (statement of Sen. Gramm).

267. 142 CoNG. ReC. S10122 (daily ed. Sept. 10, 1996) (statement of Sen. Robb).

268. See The Defense of Marriage Act, Pub. L. No. 104-199, 110 Stat. 2419 (1996).

269. See Peter Baker, President Quietly Signs Law Aimed at Gay Marriages, WASH. PosT, Sept. 22, 1996, at A21; Todd S. Purdum, Gay Rights Group Attack Clinton on Midnight Signing, N.Y. Times, Sept. 22, 1996, at 22; David Willman, Clinton Signs Marriage Act, Lauds GOP on Health Bill, L.A. TIMES, Sept. 22, 1996, at 22. 
Concern that a decision to legalize same sex marriage in Hawaii would lead to gay and lesbian couples travelling to Hawaii to marry and then seeking recognition of those marriages in their home state also led to widespread debate on this issue on the state level. Many constitutional scholars contend that the "public policy exception" of the Full Faith and Credit clause ${ }^{270}$ guarantees states the right to refuse to recognize a marriage sanctioned by another state. ${ }^{271}$ Despite the questionable need for such legislation, as of 1998 , legislators in twenty-nine states have enacted bills to ensure nullification of same sex marriages performed in $\mathrm{Ha}$ waii. ${ }^{272}$ The debate in these states has also focused on the morality of same sex marriage and the meaning of commitment in marriage. These debates have included the traditional "vocabulary of morals"273 and have helped to clarify the moral underpinnings of various states' marriage laws. For example, an extended legislative debate on a bill to prohibit recognition of same sex marriages in Kentucky, included moral discourse on both sides. ${ }^{274}$ The legislator sponsoring the bill based much of his testimony on Christian teachings, noting that "[t]raditional marriages have been ordained by all major religions and every major civilization." 275 Another legislator, opposing the bill, invoked the "Golden Rule" and

270. U.S. CoNST. art. IV, § 1; see also Nevada v. Hall, 440 U.S. 410, 422 (1979) (noting that "the Full Faith and Credit Clause does not require a state to apply another state's law in violation of its own legitimate public policy").

271. See Larry Kramer, Same-Sex Marriage, Conflict of Laws, and the Unconstitutional Public Policy Exception, 106 YALE LJ. 1965, 1971, 1975 (1997). Kramer believes the exception would permit states to refuse to recognize same sex marriages, but argues that it is unconstitutional. See id. at 1966. Some scholars have also argued that the Full Faith and Credit Clause would require other states to recognize same sex marriages performed in other states. See Lynn D. Wardle, A Critical Analysis of Constitutional Claims for Same-Sex Marriage, 1996 BYU L. REv. 1, 17 n.65 (1996); see also Symposium, Interjurisdictional Marriage Recognition (Part II), 32 CREIGHTON L. Rev. 1045 (1999); Sandra Cavazos, Comment, Harmful to None: Why California should Recognize Out-of-State Same-Sex Marriages Under Its Current Marital Choice of Law Rule, 9 UCLA Women's LJ. 133 (1998); John G. Culhane, Uprooting the Arguments Against Same-Sex Marriage, 20 CaRDozo L. REV. 1119 (1999).

272. According to a state-by-state survey conducted by the National Gay and Lesbian Task Force, thirty states have enacted bills banning same sex marriage since 1995. They are: Alabama, Alaska, Arizona, Arkansas, Delaware, Florida, Georgia, Hawaii, Idaho, Illinois, Indiana, Iowa, Kansas, Kentucky, Maine, Michigan, Minnesota, Mississippi, Missouri, Montana, North Carolina, North Dakota, Oklahoma, Pennsylvania, South Carolina, South Dakota, Tennessee, Utah, Virginia, and Washington. See National Gay and Lesbian Task Force, Anti Same Sex Marriage Laws in the U.S., December 1998 (last modified Dec. 1998) <http://www.ngltf.org/downloads/marriage1298.gif>; see also Philip L. Bartlett, Recent Legislation: Same Sex Marriage, 36 HARV. J. ON LEGIS. 581 (1999).

273. Schneider, Marriage, Morals, supra note 1, at 505.

274. See, e.g., infra notes 275-76 and accompanying text.

275. Joseph Gerth, 1998 Kentucky General Assembly; Bill Opposing Gay Marriage Clears, COURIER-JOURNAL, March 4, 1998, at 01A (quoting Rep. Sheldon Baugh). 
"Judeo-Christian tradition" to urge that Kentucky courts respect the choices of those in sister states. ${ }^{276}$ Similar debates on same sex marriage have occurred across the country. 277

The debate among family law scholars about same sex marriage has also reawakened discourse about the meaning of marriage and the law's role in regulating access to marriage. A significant part of the debate has focused on moral questions. One scholar asked "What are the costs, in terms of pain and suffering, to children of couples married in Hawaii? How does the legal status of marriage change the commitments of the partners to each other? How does marriage reinforce love, honor and the responsibility one feels for one's partner?"278 Many of these scholars, either advocating or opposing same-sex marriage, do so on both legal ${ }^{279}$ and moral grounds. ${ }^{280}$ Moral arguments examine the meaning of lifetime love and commitment in marriage and stress the value and importance of the institution of marriage. ${ }^{281}$

\section{Pre-Marital Procedures: Covenants and Counseling}

Until recently, family law has done little to reexamine or alter the longstanding formal prerequisites to marriage. ${ }^{282}$ One method states ${ }^{283}$

276. Id. (quoting Rep. Michael Bowling).

277. See, e.g., Washington Bans Gay Marriage, CHI. TRIB., Feb. 8, 1998, at A7.

278. Seth F. Kreimer, Territoriality and Moral Dissensus: Thoughts on Abortion, Slavery, Gay Marriage and Family Values, 16 QUINNIPIAC L. REv. 161 (1997).

279. See, e.g., Symposium, Constructing Family, Constructing Change: Shifting Legal Perspectives on Same-Sex Relationships, 7 TEMP. PoL. \& CIV. RTS. L. Rev. 245 (1998); Claudia A. Lewis, Note, From This Day Forward: A Feminine Moral Discourse on Homosexual Marriage, 97 YALE LJ. 1783, 1784 (1988) (arguing that marriage allows individuals to make a public, intimate commitment that is recognized by the larger community).

280. See, e.g., Wiliam N. Eskridge, Jr., The Case for Same-Sex Marriage: From Sexual LIBERTY To CIVILZED COMMTMMENT 4 (1996) (arguing that advocates for same sex marriage "valorize" the meaning of commitment in marriage); Carlos A. Ball, Moral Foundations for a Discourse on Same-Sex Marriage: Looking Beyond Political Liberalism, 85 Geo. L.J. 1871, 1877 (1997) (arguing that the shift in priorities among many gays and lesbians from tolerance to acceptance requires strategies and may require focusing on gay couples' need for the shared goal of love and commitment); Arthur S. Leonard, Going for the Brass Ring: The Case for Same-Sex Marriage, 82 CoRNELL L. Rev. 572, 582 (1997) (reviewing William N. Eskridge, JR., THE CASE for SaME-SeX Marriage: From SEXUAL LIBERTY to CIVILIZED COMMITMENT (1997) and examining the meaning of commitment in marriage and arguing that access to legal marriage will strengthen gay people's commitment to each other and reinforce their family ties to the ultimate benefit not only of themselves but the community).

281. See Leonard, supra note 280 , at 582.

282. Jana Singer has also characterized the changes in the regulation of premarital requirements as "minor" over the past two decades. See Singer, supra note 1, at 1469.

283. Regulation of access to marriage, like most areas of family law, has traditionally been an 
have used to regulate marriage formation are requirements that couples obtain a license prior to marriage and participate in a formal ceremony. ${ }^{284}$ Every state requires parties to obtain a license before marriage. ${ }^{285}$ In order to obtain a license, parties to the marriage must provide information that demonstrates their eligibility to marry: age, relationship, if any, between the prospective spouses and prior marriages. ${ }^{286}$ Many states also require a brief waiting period and some kind of medical test. 287

A formal ceremony solemnizing the marriage is also provided for in all states' statutes. ${ }^{288}$ These statutes authorize various religious and civic officers to perform marriages, but generally do not require any particular form or location for the ceremony. ${ }^{289}$ Although laws regarding licensure and solemnization of marriage have always been the subject of secular state control in this country, these laws are directly traceable to the ecclesiastical courts and canon law of medieval Europe and England. ${ }^{290}$ Thus, while these requirements have many secular goals-record keeping, public health, prevention of fraud-they were also grounded in moral concerns such as preventing sexual relationships among family members and preserving parental authority. ${ }^{291}$ The state has an impact on the level of moral discourse to the extent to which it regulates marriage formation.

The force of these statutes governing access to marriage has been significantly eroded over the last century. State policies in favor of upholding marriage have led to decisions that generally validate marriages where there is an absence of a license or an improper license. ${ }^{292}$ Addi-

area of regulation left to each state. See Michael Grossberg, Crossing Boundaries: NineteenthCentury Domestic Relations Law and the Merger of Family and Legal History, 1985 AM. B. Found. RES. J. 799, 819 (1985). Cases establishing a right to marry, however, have been interpreted as limiting states' power to impose barriers to marriage. See supra notes 251-52 and accompanying text.

284. See CLARK, supra note 126 , at 34 (stating that license and solemnization laws exist throughout the country).

285. See $i d$. Some states have carved out exceptions to the licensing requirement. See id. at 34-35. Additionally, the licensing and solemnization requirements do not preclude the formation of a marriage without a license and ceremony in the thirteen states and the District of Columbia that recognize common law marriage. See id. at $45-47 \&$ n.11.

286. See id. at 35 .

287. See id. at 36.

288. See id. at 37 .

289. The only exception is West Virginia. See W. VA. CODE $\S 48-1-12 c$ (1980).

290. See CLARK, supra note 126, at 31; SWISHER ET AL, supra note 127, at 5 .

291. See ClARK, supra note 126, at 21-31 (describing the origins of the justifications for the regulation of entry into marriage as both civil and religious).

292. See F.M. English, Annotation, Validity of Solemnized Marriage as Affected by Absence of License Required by Statute, 61 A.L.R. 2d 847 (1958). In some states, like New York, the statute provides expressly that lack of a license will not invalidate a ceremonial marriage. See N.Y. DoM. 
tionally, although common law marriage is only recognized in twelve states and the District of Columbia, ${ }^{293}$ large numbers of informal marriages are validated because conflict of laws rules require a state to recognize a common law marriage if valid where formed. ${ }^{294}$

Recently, this trend toward liberalizing enforcement of pre-marital procedures has been slowed by the consideration and, in some cases, enactment of new requirements. While many states have considered the possibility of reinstating fault grounds as a way of reducing the number of divorces, ${ }^{295}$ some legislators have concluded that another method of encouraging commitment between married couples is to encourage greater reflection before marrying. 296

States have considered a variety of proposals designed to encourage couples to approach marriage as a lifetime commitment and enter into it more cautiously. The legislation that has received the most attention is the covenant marriage laws Louisiana enacted in June, 1997.297 This statute creates a new class of marriage, a "covenant marriage," defined as a union between "one male and one female who understand and agree that the marriage between them is a lifelong relationship." 298 The couple must make the commitment to a more permanent marriage knowingly ${ }^{299}$ by signing a Declaration of Intent. ${ }^{300}$ This declaration cannot be executed until after pre-marital counseling by a religious or secular marriage counselor. ${ }^{301}$ The content of the counseling must include discussion of the purpose of marriage and the commitment each individual makes to the other. $^{302}$

Since the adoption of Louisiana's statute, ${ }^{303}$ several other states have considered bills that would give couples contemplating marriage a covenant marriage option. ${ }^{304}$ During the 1997-98 legislative session, more than

REL LAW $\S 25$ (McKinney 1988).

293. See ClaRK, supra note 126.

294. See Albert A. EmRENZweig, A Treatise on the Conflict of laws 380 (1962).

295. See discussion infra Part III.C.1.b.

296. See, e.g., Legislating Marriage and Divorce, 5 STATE CAPTTOLS REP. 30 (1997).

297. See LA. REv. STAt. ANN. § 9:272 (West Supp. 1999). The statute also focuses on divorce grounds, providing for an alternative to no-fault divorce.

298. LA. Rev. Stat. ANn. § 9:272(A) (West Supp. 1999).

299. See id. § 9-273(A)(1).

300. See id. $\$ 9-272(\mathrm{~B})$.

301. See id. § 9-273(A)(2)(a).

302. See id.

303. As of March, 1998, 400 couples have opted for the "high-test" marriage in Louisiana. See Ervin Dyer, Legislature Taking Interest in Marriage, PrtT. Post-GAZETIE, Mar. 27, 1998, at 4.

304. See id. 
a third of the other state legislatures proposed counseling requirements, divorce waiting periods, or abuse prevention training. ${ }^{305}$ While many of the legislators were very likely motivated by political rather than moral considerations, these proposed reforms have resulted in a meaningful debate about the law's role in regulating access to marriage. ${ }^{306}$ Much of the debate turns on issues relating to the moral justification for such legislation. ${ }^{307}$ The debates focus attention on the nature of the marriage commitment and the importance of promoting strong marriages to protect children. ${ }^{308}$ In Connecticut, a legislator supporting a bill that would require engaged couples under 30 to complete ten hours of premarital counseling debated its importance by invoking both the costs to the state of failed marriages and the trauma to couples and children of such marriages. ${ }^{309}$ Modeled on a premarital counseling program developed by the Catholic Church, the legislation also emphasizes the need for couples to reflect on the responsibilities of marriage. ${ }^{310}$

The idea of imposing more hurdles on the front end of the marital commitment has also received more attention from family law scholars and policymakers. ${ }^{311}$ As William Galston commented in urging interventions to slow the rate of divorce:

It is stunning how much time public education spends on sex while failing to discuss marriage in any sustained manner .... These educational efforts should be reinforced by the law. In most states it is much harder to get a driver's license than

305. See National Conference of State Legislatures, 1998 "Covenant Marriage” LegISLATION (1998) [hereinafter NCSL]; see also Dyer, supra note 303, at 4.

306. See infra notes 307-12 and accompanying text; see generally Jay Macke, Note, Of Covenants and Conflicts-When "I Do" Means More Than It Used to, But Less Than You Thought, 59 Oнго ST. LJ. 1377 (1998) (discussing the policy debates surrounding covenant marriage and no-fault reform); Gary H. Nichols, Note, Covenant Marriage: Should Tennessee Join the Noble Experiment, 29 U. MEM. L. REv. 397 (1999); Rebecca E. Silberbogen, Note, Does the Dissolution of Covenant Marriages Mirror Common Law England's Subordination of Women?, 5 WM. \& MARY J. WOMEN \& L. 207 (1998) (comparing and contrasting covenant marriage with marriage in Tudor and Stuart periods of English history as they affect the subordination of women).

307. Compare Lynne Marie Kohn, Covenant Marriage Endorses Lifetime Vows, VIRGinianPLOT \& THE LEDGER-STAR, Feb. 21, 1998, at B8 with Linda Valdez, Legislating Marriage An Insult to Human Relationships, ARZZ RepUBLIC, Feb. 20, 1998, at B4. See Katherine Shaw Spaht \& Ashton Applewhite, Would Louisiana's 'Covenant Marriage' Be a Good Idea for America? Opposing Views, WASH. TIMES, Oct. 6, 1997, at 24.

308. See supra note 307 and accompanying text.

309. See Daniela Altimari \& Rita A. Niro, A Marriage Proposal: Counseling Precedes a Walk Down the Aisle, HartFord CoURANT, Feb. 17, 1997, at Al.

310. See id.

311. See, e.g., Margaret F. Brinig, Status, Contract and Covenant, 79 CORNELL L. Rev. 1573, 159499 (1994) (book review) (arguing that the use of covenant may be a way to strengthen marriage without reverting to traditional roles); Galston, supra note 7, at 21. 
a marriage license. At a minimum, each state should impose a reasonable waiting period (at least one month, but preferably three) and require couples to show that they have completed a program of counseling (religious or secular) preparing them for marriage..$^{312}$

Both legislative debates and scholarly commentary have begun to reexamine the institution of marriage during the 1990s. No major legislative reforms have yet occurred. However, the law's role in regulating who shall marry and what procedures should be followed before marriage has been explored in ways that may lead to a more coherent understanding of the role of marriage in ensuring commitment to children.

\section{B. Reinforcing Responsibilities and Commitments Within Families}

\section{Family Violence}

\section{a. Eroding the Doctrine of Family Autonomy}

One of the most deeply embedded principles in American family law is the principle of family autonomy, which limits the state's intervention in the affairs of the intact family. ${ }^{313} \mathrm{~A}$ variety of justifications have been offered to support this limit on state intervention in family affairs. These include a reluctance to interfere with the husband's authority, ${ }^{314}$ concern about courts' abilities to fashion and enforce appropriate remedies for intrafamily disputes, ${ }^{315}$ a belief that the adversarial process will aggravate rather than resolve family conflicts ${ }^{316}$ and, perhaps the most entrenched, that families must be ensured privacy to flourish. ${ }^{317}$ Except in extreme cases, the principle of family autonomy has been invoked to justify courts' refusals to provide a direct remedy for financially neglected spouses, ${ }^{318}$ to resolve a dispute between parents about their children's ed-

312. Galston, supra note 7 , at 21 .

313. The right of privacy has a constitutional dimension going back to the early 20th century. See, e.g., Pierce v. Society of Sisters, 268 U.S. 510 (1925); Meyer v. Nebraska, 262 U.S. 390 (1923).

314. See D. Kelly Weisberg \& Susan Frelich Appleton, Modern Family LaW 257 (1998); Nadine Taub \& Elizabeth Schneider, Women's Subordination and the Role of Law, in THE PoLmcs of Law: A Progressive Crmque 151, 155-56 (David Kairys ed., 1990).

315. See Carl E. Schneider \& Margaret F. Brinig. An Invitation to Family Law: PrincI. PLES, PROCESS AND PERSPECTIVES 172-74 (1996).

316. See id.

317. See id.

318. See, e.g., McGuire v. McGuire, 59 N.W.2d 336, 342 (Neb. 1953) (denying wife's action to obligate husband to provide suitable maintenance and finding that " $[t]$ he living standards of a family are a matter of concern to the household, and not for the courts to determine, even though the 


\section{ucation, ${ }^{319}$ or to alter the traditional gendered roles in marriage..$^{320}$}

This doctrine has been criticized because it reinforces patriarchal family relationships and leaves women and children vulnerable. ${ }^{321} \mathrm{De}-$ spite this critique, the principle of non-interference in family life to protect the welfare of a dependent spouse is still strong today. ${ }^{322}$ However, the doctrine of family autonomy has eroded in the last thirty years. ${ }^{323}$ These exceptions have resulted in increased state regulation of the intact family to protect vulnerable family members from abuse. ${ }^{324}$ An examination of the law's role in enforcing prenuptial agreements and punishing perpetrators of family violence reveals that this is an area in which both the language and content of the law furthers the core value of protecting vulnerable family members. ${ }^{325}$

husband's attitude toward his wife, according to his wealth and circumstances, leaves little to be said in his behalf"); Commonwealth v. George, 56 A.2d 228, 231 (Pa. 1948) (denying wife's claim for support and stating that the statute authorizing a support order was not intended to make the court a "sounding board for domestic financial disagreements nor a board of arbitration to determine the extent to which a husband is required to recognize the budget suggested by the wife . . "). But see Miller v. Miller, 30 N.W.2d 509, 511 (Mich. 1948) (holding that when "there is great discrepancy between a husband's large income and the very small and insignificant amount he is willing to pay [his wife] for her maintenance and support, the court is justified in finding that the acts of the husband constitute non-support and extreme cruelty").

319. See Kilgrow v. Kilgrow, 107 So. $2 d 885,889$ (Ala. 1958) (refusing to enforce a prenuptial agreement providing that child will be raised in father's religion).

320. See Graham v. Graham, 33 F. Supp. 936 (E.D. Mich. 1940) (refusing to enforce an agreement between husband and wife, which provided that wife would pay the husband $\$ 300$ per week to quit his job so he would travel with her).

321. See, e.g., Martha Minow, Making All the Difference: Inclusion, Exclusion and AMERICAN LAW 279 (1990) ("Within a sphere cordoned off as 'private,' removed from state intervention, family members remain individuals who have or who lack rights to appeal to the state .... The law thus helped to shield from view the governmental refusal to see some kinds of power or abuse as warranting public restraint.").

322. See, e.g., In re Marriage of Mathiasen, $268 \mathrm{Cal}$. Rptr. 895, 897 (1990) (invalidating an agreement between husband and wife to share equally in support expenses during their marriage).

323. These developments are evidence that the trend Carl Schneider identified in 1994 toward greater non-interference by the state in the family has not taken hold. See Schneider, Marriage, Morals, supra note 1 , at 550.

324. See infra notes $332-46,352-57$ and accompanying text.

325. Contracts setting forth parties' marital duties and responsibilities have recently begun to gain the approval of family law scholars and courts. Some early advocates of this kind of private ordering did so on theories based on the importance of reinforcing autonomy and individual rights in families. See Marjorie Maguire Shultz, Contractual Ordering of Marriage: A New Model for State Policy, 70 CAL. L. REv. 204, 329-30 (1982). More recently scholars have focused on the value of these agreements to reinforce important marital obligations and strengthen the marital commitment. See Eric Rasmusen \& Jeffrey Evans Stake, Lifting the Veil of Ignorance: Personalizing the Marriage Contract, 73 IND. LJ. 453, 464-65, 501-02 (1998) (advocating that couples should have options to establish terms of matrimony, grounds for divorce and terms for dissolution); Elizabeth S. Scott, Rational Decisionmaking About Marriage and Divorce, 76 VA. L. Rev. 9, 42-44, 79-90 (1990) (advo- 


\section{b. New Laws: Reducing Domestic Violence and Child Abuse}

\section{i. Domestic Violence}

Historically, the principle of family autonomy was used to justify the state's non-interference in cases where one spouse or intimate partner physically abused another. In one of the early cases holding that the negative effects of state intervention in the family outweigh the "evils" of a husband's physical abuse of his wife, the court reasoned:

The violence complained of would without question have constituted a battery if the subject of it had not been the defendant's wife. The question is how far that fact affects the case. . . . Our conclusion is that family government is recognized by law as being as complete in itself as the State government is in itself, and yet subordinate to it; and that we will not interfere with or attempt to control it, in favor of either husband or wife, unless in cases where permanent or malicious injury is inflicted or threatened, or the condition of the party is intolerable. For, however great are the evils of ill temper, quarrels, and even personal conflicts inflicting only temporary pain, they are not comparable with the evils which would result from raising the curtain, and exposing to public curiosity and criticism, the nursery and the bed chamber. ${ }^{326}$

In the 1870s, the women's movement and temperance activists called for legislation to eradicate wife abuse, ${ }^{327}$ and by the last quarter of the nineteenth century, a husband no longer had a "right" to beat his wife. ${ }^{328}$ Notwithstanding these legal changes, wife abuse continued to be justified or ignored by the police, courts, and general public. ${ }^{329}$ This view prevailed until the 1970 s, when a coalition of feminists, legislators, academics, and advocates brought domestic violence to the public attention

cating the enforceability of agreements in which couples set forth marital obligations and conditions under which they agree marriage could be dissolved).

326. State v. Rhodes, 61 N.C. 349,350 (1868).

327. See Jane C. Murphy, Lawyering for Social Change: The Power of the Narrative in Domestic Violence Law Reform, 21 Hofstra L. Rev. 1243, 1262 (1993) (citing Ellen C. Dubois \& Linda Gordon, Seeking Ecstasy on the Battlefield: Danger and Pleasure in Nineteenth-Century Feminist Sexual Thought, in Pleasure and Danger: Exploring Female Sexualtit 31, 42 (Carole S. Vance ed., 1984)); Elizabeth Pleck, Wife Beating in Nineteenth-Century America, in VictnMOLOGY 60, 60-61 (1979).

328. However, recent scholarship has cast doubt on the long-held view that a common law "rule of thumb" provided that a husband could beat his wife with a stick no bigger than his thumb. See Henry Ansgar Kelly, Rule of Thumb and the Folklaw of the Husband's Stick, 44 J. LEGal Educ. 341, 341-42 (1994). .

329. See Murphy, supra note 327, at 1262 (citing Elizabeth Pleck, DOMEstic Tyranny: The Making of American Social Policy Against Family Violence from Colonial Times to the Present (1987)). 


\section{once again. ${ }^{330}$}

Building on the work of feminist legal theory, ${ }^{331}$ new laws and policies aimed at protecting victims of domestic violence have been adopted across the country over the last twenty years. The legal approaches taken to protect battered women and control family violence have resulted in significant changes in family law. ${ }^{332}$

New laws include statutes permitting or requiring that spousal abuse be considered in custody and/or visitation decisions, ${ }^{333}$ and civil protection or restraining order statutes. ${ }^{334}$ Both of these types of statutory reforms provide protection to both adult victims and their children. Evaluating a parent's fitness by considering past acts of violence to other family members results in decisions that are more likely to protect children than decisions that discount or disregard spousal abuse. ${ }^{335}$ Civil pro-

330. See generally Susan Schechter, Women and Male Violence: The Visions and StRug. GLES OF THE BATTERED WOMEN's MOVEMENT (1982) (discussing the early days of the battered women's movement); Kathleen J. Tierney, The Battered Women's Movement and the Creation of the Wife Beating Problem, 29 Soc. ProBs. 207 (1982) (discussing the social movement to combat wife beating).

331. Feminist scholars illuminated the dynamics of power and gender and have developed legal theories that reflect and value women's experiences. See, e.g., CATHERINE A. MACKINNON, FEMINISM UNmodified: Discourses on LIFE aNd LAW (1987); CAROL SMART, FEMINISM AND tHE PoWER OF LAW (1989). Feminist theory helped other scholars and practitioners to recognize that women's experience of violence in their homes and in their relationships is critical to an understanding of women's oppression. See, e.g., Martha R. Mahoney, Legal Images of Battered Women: Redefining the Issue of Separation, 90 Mich. L. Rev. 1, 1-10 (1991).

332. Changes in criminal laws including creating new criminal sanctions to fit the patterns of domestic violence and encouraging the enforcement of existing criminal sanctions in domestic situations have also developed in the last decade. See Bonnie J. Campbell, U.S. Dept. of Justice, A Message from Violence Against Women Office Director, Bonnie J. Campbell, 1 Violence AGAINST Wo. MEN ACT NEwS, July 1996 (last modified July 2, 1996) <http://www.usdoj.gov/vawo/newsletter/ bjc796.htm>. See generally Developments in the Law-Legal Responses to Domestic Violence, 106 HARv. L. Rev. 1498, 1528-51 (1993) (discussing new state and federal responses to domestic violence).

333. See infra notes $405-14$ and accompanying text.

334. All 50 states and the District of Columbia now have some form of protection order statute. See Peter Finn \& Sarah Colson, U.S. Dep't of Justice, Civil Protection Orders: LegislaTION, CuRrent Court Practice, and Enforcement 7 (1990). Since its publication, Delaware and Arkansas have enacted civil protection order statutes. See ARK. CODE ANN. § 9-15-101 to 9-15-302 (Michie 1998); DEL. CODE ANN. tit. 10, $\$ 1041-48$ (protection from abuse proceedings); DEL. CODE ANN. tit. 13, \& 701(A)-711(A) (1993 \& Supp. 1996) (child protection from domestic violence act). Statutes typically provide for eviction of the abuser from the home, temporary child custody, and a prohibition against continued abuse. Some state statutes provide for monetary relief for the duration of the order. The duration of the order varies with each state and ranges from 60 days to 3 years. See FinN \& Colson, supra note 334, at 33 \& Fig. 9; see also Catherine F. Klein \& Leslye E. Orloff, Providing Legal Protection for Battered Women: An Analysis of State Statutes and Case Law, 21 HOFSTRA L. Rev. 801, 1085-87 (1993).

335. See Klein \& Orloff, supra note 334 , at $961-65$. 
tection orders can provide abused women and their children with a quick and easily accessible remedy that provides housing, financial relief, and an order for custody. ${ }^{336}$ While there is some controversy about the effectiveness of such orders in cases involving severe violence, ${ }^{337}$ most advocates and scholars agree that, under many circumstances, these statutes have improved the lives of women and children..$^{338}$

During the same period, Congress followed the states in legislating to reduce domestic violence. In 1994, Congress enacted the Violence Against Women Act (VAWA), which, among other things, makes certain acts of domestic violence federal crimes, ${ }^{339}$ provides a civil rights remedy for victims of domestic violence, ${ }^{340}$ and provides federal funding for enhanced state services for victims of domestic violence. ${ }^{341}$ Along with mandating interstate enforcement of protective orders, ${ }^{342}$ establishing a National Domestic Violence Hotline, ${ }^{343}$ and providing training for state and federal judges, ${ }^{344}$ the Violence Against Women Act enables victims of gender-motivated crimes to sue their attackers in federal court for violating their civil rights. ${ }^{345}$ The legislation also begins to address the needs of undocumented immigrant women who are abused by their husbands..$^{346}$

\section{ii. Child Abuse}

Historically, the government was less reluctant to interfere in the family to protect children from abuse and neglect. ${ }^{347}$ The juvenile court

336. See id. at $910-1044$.

337. See, e.g., Eve S. Buzawa \& Carl G. Buzawa, Introduction to Do ARRESTS AND RESTRAINING ORDERS Work? 1, 1-5 (Eve S. Buzawa \& Carl G. Buzawa eds., 1996).

338. See Lenore E. Walker, The Battered Woman 210-12 (1979); Molly Chaudhiri \& Kathleen Daly, Do Restraining Orders Help? Battered Women's Experience with Male Violence and Legal Process, in Domestic Violence 227, $245-47$ (Eve S. Buzawa \& Carl G. Buzawa eds., 1992); Janice Grau et al., Restraining Orders for Battered Women: Issues of Access and Efficacy, 4 WomeN \& PoL., 13, 19-20 (Fall 1984) (concluding that protection orders are most effective in curtailing abuse when the level of violence is not severe); Lisa G. Lerman, A Model State Act: Remedies for Domestic Abuse, 21 HARv. J. ON LEGIS. 61, 70 n.35 (1984).

339. See 18 U.S.C.A. \$\$ 2261-2262 (West Supp. 1998).

340. See 42 U.S.C.A. $\$ 13981$ (West 1995).

341. See id. § 3796gg-hh, § 13971 (West 1995 and Supp. 1998).

342. See 18 U.S.C.A. $\S 2265$ (West Supp. 1998).

343. See 42 U.S.C.A. \$ 10416 (West 1995).

344. See id. \$ 13991.

345. See id. § 13981.

346. See Leslye E. Orloff et al., With No Place to Turn: Improving Legal Advocacy for Battered Immigrant Women, 29 FAM. L.Q. 313, 324-25 (1995).

347. The early child welfare programs in this country were modeled on England's Elizabethan Poor Law, which separated the children of the poor from their families. See Act for Relief of the Poor, 43 Eliz., ch.2 § 1 (1601 Eng.). Massachusetts, Connecticut, and Virginia, for example, specifi- 
system in the United States was created at the beginning of the 20th century to assist the State acting as parens patriae, or as "father." 348 Efforts to protect children from abusive or neglectful caretakers have taken many forms, from the creation of large orphanages and foundling homes to the relocation of children from the city to the country. ${ }^{349}$ Eventually, most jurisdictions settled on the present day foster care system as a way to protect children whose families apparently could not care for them. ${ }^{350}$ However, juvenile courts have been the subject of criticism and calls for reform since they were first created. ${ }^{351}$

Recent reform efforts have emphasized a greater commitment to protecting children over the rights of parents. These reforms have included development of state laws that mandate compiling records of child abuse ${ }^{352}$ and reporting of abuse. ${ }^{353}$ Most recently, the federal standards for governing removal of children have shifted the emphasis from reunification with parents to permanency planning for children. In November of 1997, President Clinton signed into law the Adoption and Safe

cally authorized magistrates to "bind out" or indenture children of the poor over parental objections. homer folks, The Care of Destitute, Neglected, and Delinguent ChIldren 28-29, $96-97$ (Amo Press and The New York Times 1971) (1900). Criminal laws punishing parental child abuse or neglect also have a long history in this country. See generally LINDA GORDON, HEROES OF THER OWN Lives: THE POLTICS AND HISTORY OF FAMILY VIOLENCE (1988) (including an historical review of records of the Massachusetts Society for the Prevention of Cruelty to Children from 1880-1910); see also A. Schwartz \& H.L. Hirsh, Child Abuse and Neglect: A Survey of the Law, in CHILD ABUSE 31 (A. Carmi \& H. Zimrin eds., 1984) (examining criminal punishment of child abuse within the last two centuries). Forty-nine states and the District of Columbia have child abuse statutes that require an act of commission, an act which directly inflicts harm on the child. All but twelve states also have child abuse laws that punish omissions, the 'failure to protect' laws. See V. Pualani Enos, Prosecuting Battered Mothers: State Laws' Failure to Protect Battered Women and Abused Children, 19 HARV. WOMEN's L.J. 229, 236-38 (1996).

348. See Sanford J. Fox, Juvenile Justice Reform: An Historical Perspective, 22 Stan. L. Rev. $1187,1187-88,1192-93$ (1970).

349. See id. at 1207-12.

350. See Anthony M. Platt, The Child Savers: The Invention of Delinquency 46-74, 10136 (1969).

351. See id. at 152-63; Leonard P. Edwards, The Juvenile Court and the Role of the Juvenile Court Judge, 43 Juv. \& FAM. CT. J. 1, 17-18 (1992).

352. In 1995, investigations by child protective services (CPS) agencies in 50 states determined that over 1 million children were victims of substantiated or indicated child abuse and neglect. CPS agencies investigated an estimated 2 million reports alleging the maltreatment of almost 3 million children. See U.S. Dep'r of Health and Human Servs., NAT'l CTR. on Child Abuse \& NegLECT, Child Maltreatment 1995: Reports from the States to the National Child Abuse and Neglect Data System ix (1997).

353. See National Clearinghouse on Child Abuse and Neglect, U.S. Dep't of Health \& Human Servs., Child abuse and Neglect State Statute Series No. 1, Reporting Laws: DefintIONS OF CHLD ABUSE AND NEGLECT (1996) (compiling state reporting laws). 
Families Act. ${ }^{354}$ States must now comply with this Act in order to receive federal funds. ${ }^{355}$ This statute seeks to avoid the harm that children experience from extended foster care placement. ${ }^{356}$ Under the Act, a state's receipt of federal funds is conditioned upon establishing procedures that make child welfare bureaucracies move more quickly to rule out parents as caretakers, making children available for adoption sooner. ${ }^{357}$

Much of the language in the debates supporting both child abuse and domestic violence law reforms and the language of the laws themselves focuses on the public health and safety goals of these law reform efforts. ${ }^{358}$ Considerable attention is also paid, however, to the moral imperative underlying family violence legislation. Consider, for example, the following statement from the floor of Congress, which ties the issue of prevention of violence against women to the themes of responsibility and commitment to community:

354. Adoption and Safe Families Act of 1997, Pub. L. No. 105-89, 111 Stat. 2115.

355. See 42 U.S.C.A. § 671 (West Supp. 1998).

356. See, e.g., Richard Gelles, The Book of Davis: How Preserving Familes Can Cost CHIIDREN's Lives (1996); Marsha Garrison, Why Terminate Parental Rights?, 35 Stan. L. Rev. 423, 423-24 (1983) (discussing the harm to children as a result of "foster care drift"). In fact, there is much evidence that for those children who are removed, "foster care drift" continues today. A 1995 report found that:

[o]ne in ten foster children remains in state care longer than 7.4 years. At least 40,600 foster children have been in care for five years or longer, another 51,300 have been in care between three and five years. System kids, on average, live with three different families, though ten or more placements is not uncommon.

Conna Craig, "What I Need is a Mom": The Welfare State Denies Homes to Thousands of Foster Children, 73 POL'Y REv. 41, 45 (1995); see also BEYOND RHETORIC: A NEW AMERICAN AGENDA FOR Chindren and Fammies, Final Report of the National Commission on Children 288 (1991) ("In 1986, slightly fewer than $60 \%$ of children in foster care were either reunited with their families or placed with a parent, relative, or other caregiver.").

357. Hearings to determine permanent placement of children removed from parents must now begin no later than 12 months after a child enters foster care, a reduction from the former 18 month limit. See 42 U.S.C.A. § 675(5)(c) (West Supp. 1998). States must also move to terminate parental rights when a child has been in foster care for 15 of the previous 22 months. See id. $\$ 675(5)(\mathrm{e})$. The extent to which the AFSA actually fulfills its promise of providing greater protection to children is still an open question. See, e.g., M. Gordon, Drifting Through Byzantium: The Promise and Failure of the Adoption and Safe Families Act of 1997, 83 Mins. L. Rev. 637 (1999).

358. An impatience with the slow pace at which children move through the child welfare system encouraged legislators to develop such procedures even before the federal mandate. See, e.g., Act Concerning the Reporting, Investigation and Prosecution of Child Abuse and the Termination of Parental Rights, 1996 Conn. Pub. Acts 246 (Reg. Sess.) (new Connecticut statute providing that a child under the age of one year can be put up for adoption if a parent has not been in contact with the child for sixty days). Some states have also recently passed legislation permitting removal of a child at birth if a mother abuses drugs during her pregnancy. See, e.g., MASs. GEN. LAwS ANN. ch. 119, § 51A (West Supp. 1990); Nev. Rev. Stat. AnN. § 432B.330(1)(b) (Michie 1996); OKLA. Stat. ANN. tit. 10, § 7001-1.3A14.b (West Supp. 1998). 
Much of the problem is rooted in the erosion of personal responsibility, the breakdown of families, and the deterioration of community life. Each of us can contribute to the task of renewal. That is why lawmakers' insistence on sound policies that protect and assist victims, law enforcers' steadfastness in punishing perpetrators, advocates' commitment to providing counsel and much needed services, and health professionals' willingness to broaden their sphere of responsibility are so heartening. Together, we can undertake the varied efforts required to turn this threat around. ${ }^{359}$

Representative Schroeder, in protesting a last minute attempt to reduce the appropriations under the bill, referred to the important role of government in strengthening families by making the home safe from violence:

Violence against men or violence against women in the home is wrong. Violence against children in the home is wrong. Instead you see everybody now moving to say that Government should back out of all of that and we should just again go back; the home is totally off limits, and you can batter children, batter spouses, do whatever. . . . but the most important thing is the home and the family, and if the home and the family [are] the roots of violence, if the home and the family [are] absolutely tom asunder, then you are never going to get off square one when it comes to fighting crime. ${ }^{360}$

Scholars have also commented on the increased attention the law has given in the last three decades to protecting family members from abuse. ${ }^{361}$ There is broad consensus among politicians, scholars and policymakers that such developments are a healthy trend toward protecting vulnerable family members. ${ }^{362}$

\section{Recognizing Commitments in Families Created Outside Marriage}

In previous sections, this Article has dealt with changes in moral discourse in areas where family law has traditionally focused moral attention: divorce, alimony, child custody and visitation. However, limiting this discourse to these issues excludes many families created outside of marriage from the moral vision in family law. ${ }^{363}$ Recent shifts in the law

359. 140 Cong. REc. H10688 (daily ed. Oct. 4, 1994) (statement of Rep. Price).

360. 140 CoNG. REC. H5180 (daily ed. June 28, 1994) (statement of Rep. Schroeder).

361. See Elizabeth S. Scott \& Robert E. Scott, Parents as Fiduciaries, 81 VA. L. REv. 2401, 2435 (1995) ("[p]ublic concern about child abuse and neglect has increased in the past generation"); see also Garrison, supra note 76, at 103 (noting in general that "the last three decades have witnessed a wave of new limitations on parental prerogatives" and citing the strengthening of child abuse laws as one example).

362. See Herma Hill Kay \& Martha S. West, Sex-Based Discrimination 1192 (4th ed. 1996) (describing developments in research, scholarship and legislation that have "transformed the law into a protective tool for battered women" over the last 25 years).

363. Increasing numbers of children now face life in a single-parent family. In 1994, $27 \%$ of 
reveal a healthy trend toward increased attention to those who may be in most need of the law's protection, children of unmarried cohabitants.

Historically, nonmarital cohabitation was considered deviant and subject to criminal sanctions. ${ }^{364}$ Although criminal sanctions still exist, prosecutions have been rare since the 1950 s. ${ }^{365}$ Instead, until the 1980 s, the law tended to ignore couples who created families outside traditional marriage. ${ }^{366}$ This meant little or no protection for the dependent partners and children of such unions, either during the relationship or at its dissolution. Many commentators, however, attribute the law's indifference or condemnation of informal families to the fact that such families have always been disproportionately headed by women ${ }^{367}$ who are poor ${ }^{368}$ and non-white. ${ }^{369}$ As Mary Ann Glendon describes it:

Another large proportion of informal unions, especially earlier in the century, was composed of persons who belonged to subcultures of the poor, or to racial and ethnic minorities for whom the legal structures of traditional marriage and divorce were sometimes irrelevant and with whom the framers of such laws were rarely concerned-groups ignoring and ignored by traditional family law. ${ }^{370}$

children under the age of 18 lived in a female-headed family, up from 12\% in 1970. See ARLENE F. Saluter, U.S. Dep't of Commerce, Martal Status and Living ARRangements, March 1994, at viii-xii (1996).

364. See Edwin Powers, Crime and Punishment in Early Massachusetts 1620-1692: A DOCUMENTED HISTORY (1966).

365. While criminal prohibitions on cohabitation and fornication still exist in some states, prosecutions for private, consensual acts are rare. See, e.g., Doe v. Duling, 782 F.2d 1202, 1204 (4th Cir. 1986). State laws imposing criminal sanctions for sodomy still exist in about half the states. See Evan Wolfson \& Robert S. Mower, When the Police Are in Our Bedrooms, Shouldn't the Courts Go in After Them?: An Update on the Fight Against "Sodomy" Laws, 21 FordHAM URB. LJ. 997, 997 (1994).

366. See Glendon, Transformation, supra note 241 , at 254-55. Glendon points out that under the traditional family law approach, the law "wavered between expressions of moral disapproval and covert compassionate remedies" with unmarried cohabitants, such remedies were put into play only in the most "hardship" cases. Id. at 255.

367. See SalUTER, supra note 363, at ix (stating that mothers are most often the custodians of children in single parent families with $88 \%$ of children in single parent homes living with their mothers); see also Working GROUP ON WELFARE REFORM, FAMILY SUPPORT, AND INDEPENDENCE, U.S. Dep't of Health \& Human Servis., Background Papers on Welfare Reform: Child Support EN. FORCEMENT 3 (1994).

368. See Joel F. Handler \& Yeheskel Hasenfeld, We the Poor People: Work. Poverty AND WELFARE 54 (1997) (discussing the disproportionate number of female-headed households in the overall poverty population).

369. Among Black female-headed families, nearly $60 \%$ are below the poverty line. NATIONAL Resource Council. Who Cares for America's Children?: Chlld Care Policy for the 1990s, at 27 fig. 2-9 (Cheryl D. Hayes et al. eds., 1990); see also Cynthia Grant Bowman, A Feminist Proposal to Bring Back Common Law Marriage, 75 OR. L. Rev. 709 (1996) (tracing history of common law marriage and finding that its abolition hurt poor, non-white women and children the most).

370. Glendon, Transformation, supra note 241 , at 253. 
While the last two decades have not seen significant change in the law on common law marriage, ${ }^{371}$ there has been a significant movement toward extending the law's protection to individuals "who have become dependent or suffered detriment over the course of a long relationship" 372 and to children of those unions. ${ }^{373}$

Other commentators have observed this trend and recognized its moral dimension. To some extent, Carl Schneider has recognized the increased moral discourse in the law of unmarried cohabitants in his singling out of contractarianism as a counter trend to the diminution of moral discourse in family law. ${ }^{374} \mathrm{He}$ notes, as examples of this counter trend, courts' recent willingness to enforce contracts or imply contracts between unmarried cohabitants. ${ }^{375}$ Mary Ann Glendon, while disapproving of many recent trends, sees the increased protection for unmarried cohabitants, particularly the children of those unions, as appropriate:

Traditional family law rigorously policed the boundaries of the legitimate family. It carefully regulated the conditions under which children born outside legal marriage would be permitted to acquire rights in relation to their parents, especially the allimportant right of inheritance. As for couples who had not entered into formal marriage, the law, for the most part, ignored them, or pretended to ignore them..$^{376}$ Over time, the focus of the law relating to children born outside marriage has appropriately shifted from preoccupation with wealth and status to concern for the children themselves. Not only have children of unwed parents been accorded substantially equal rights to support and derived benefits, the establishment of paternity (without which these rights would be meaningless) has everywhere been facilitated, both in law and through technological advances. ${ }^{377}$

Despite his overall concern with strengthening marriage, Milton Regan has also noted the moral imperative of protecting dependent partners and children of unmarried cohabitants noting that "unmarried cohabitation ... is widely accepted and raises important issues of responsibility in intimate relationships. Failure to respond to the claims of cohabitants

371. See Bowman, supra note 369 , at 740 (noting that ten states abolished common law marriage between 1921 and 1959, and only four have recognized it since that time).

372. GLENDON. TRANSFORMATION, supra note 241 , at 288.

373. See Larry L. Bumpass et al., Cohabitation and the Declining Rates of Marriage, $53 \mathrm{~J}$. MAR. \& FAM. 913, 919 (1991).

374. See Schneider, Moral Discourse, supra note 1, at 1832.

375. See id. at 1829-30 (recognizing that the areas of family law "susceptible to contractual analysis" are areas in which the courts have had increased interest in moral analysis, but concluding that contract law's emphasis on private ordering, among other reasons, will ultimately contribute to the trend toward diminished moral discourse).

376. Glendon, Transformation, supra note 241 , at 253.

377. Id. at 285. See also Krause, supra note 80 , at 116-20. 
thus could undermine the relational ethic that family law should reinforce." 378

\section{Family Dissolution}

\section{Access to Divorce}

\section{a. What No-Fault Divorce Really Means}

Before analyzing the moral implications of the shift to no-fault grounds for divorce, further clarification of the way these new laws changed divorce practice is helpful in understanding their impact. First, even prior to widespread adoption of no-fault grounds, couples had obtained divorces by consent through collusion and, in some instances, perjured testimony. ${ }^{379}$ As courts and litigants became increasingly frustrated with fitting the circumstances of the breakdown of their marriage into the existing fault categories, ${ }^{380}$ mutually agreed upon fabricated testimony became commonplace. ${ }^{381}$ Thus, the "consent divorce disguised as fault divorce ... had become a relatively common way of terminating a marriage."382

Second, the adoption of no-fault grounds for divorce resulted in divorce on demand-an immediate right to file for divorce without waiting and without the consent of the other spouse (divorce on demand) in only a few states. ${ }^{383}$ In most states, a divorce without the consent of the other spouse (unilateral divorce) cannot be granted unless the parties have been separated for a minimum period of time ranging from six months to three years. ${ }^{384} \mathrm{~A}$ few states still do not permit unilateral divorce at all. ${ }^{385}$ Additionally, in most states there are significant procedural barriers to ob-

378. REGAN, supra note 90, at 124.

379. See generally ELLMAN ET AL, supra note 232. law).

380. See GleNDON, supra note 78 , at 76 (contrasting U.S. and European treatment of divorce

381. See Herbert Jacob, Silent Revolution: The Transformation of Divorce law in the UNTED STATES (1988).

382. GLENDON, supra note 78 , at 65 .

383. See Ira Mark Ellman \& Sharon Lohr, Marriage as Contract, Opportunistic Violence, and Other Bad Arguments for Fault Divorce, 1997 U. ILL. L. Rev. 719, 723 (1997).

384. See id. at 723.

385. At least three states require mutual consent and a separation agreement before a divorce can be granted. See Miss. Code ANn. § 93-5-1 to § 93-5-2 (1994); N.Y. DoM. Rel. LAw $\$ 170$ (McKinney 1988); TENN. CODE ANN. § 36-4-103(b) (1996). 
taining a no-fault divorce. ${ }^{386}$ Thus, the perception that the no-fault revolution has resulted in easy access to divorce is not true.

In enacting the first no-fault statute, California reformers never intended to eliminate fault or accountability from the divorce process:

We would underscore that this is not to say that we think immoral or reprehensible conduct should be overlooked. Quite the contrary, the purpose of adopting the standard we suggest would be to permit-indeed to require-the Court to inquire into the whole picture of the marriage. Misconduct would thus be completely relevant, and could be completely explored. ${ }^{387}$

Indeed, the adoption of no-fault grounds did not eliminate the role of fault in the laws governing access to divorce. ${ }^{388}$ Fault continues to play a role in custody, property and alimony issues in many states. ${ }^{389}$

An evaluation of the impact of no-fault divorce on the values of commitment and responsibility to family members must also acknowledge that at least some of the goals underlying the adoption of no-fault divorce have been accomplished. In addition to addressing concerns about the integrity of the judicial system that resulted from the perjury and collusion in the fault era, ${ }^{390}$ no-fault divorce was intended to reduce the trauma of breakup on the family, particularly the children. ${ }^{391}$ Even if they were delayed, divorces occurred with or without the availability of no-fault grounds. ${ }^{392}$ The idea under no-fault was that the process of ob-

386. See Jane C. Murphy, Access to Legal Remedies: The Crisis in Family Law, 8 BYU J. PuB. L. 123, 124 (1993).

387. 1966 Report By the Governor's Commission on the Family cited in JUDITH AREEN, CASES and Materlals on Family Law 342 (1992).

388. See Ira Mark Ellman, The Place of Fault in a Modern Divorce Law, 28 ARIz. ST. LJ. $773,778-80$ (1996) (analyzing and categorizing each state's consideration of fault in alimony and property decisions and finding that only twenty states can be categorized as "pure no-fault" in that they exclude consideration of marital misconduct from alimony and marital property decisions unless the misconduct has affected the property available or the financial need of a spouse); see also Peter Swisher, Reassessing Fault Factors in No-Fault Divorce, 31 FAM. L.Q. 269, 292-300 (1997).

389. See Swisher, supra note 388, at 320 n.158.

390. See Olive M. Stone, Moral Judgments and Material Provision in Divorce, 3 FAM. L.Q. 371, 371 (1969).

391. See Handbook of the Nat'l Conference of Comm'rs on Unif. State laws 181 (1965) [hereinafter HANDBOOK].

392. Furthermore, while the existence of no-fault grounds for divorce has certainly made getting a divorce easier, there is some question as to what role it has played in increasing the rate of divorce in this country. See, e.g., Dana Milbank, Blame Game: No-Fault Divorce Law Is Assailed in Michigan, and Debate Heats up, WALl ST. J., Jan. 5, 1996, at Al (citing conflicting studies on contribution of no-fault divorce to increased divorce). Although the divorce rate accelerated after the adoption of no-fault, it began rising sharply in 1965 , before the implementation of no-fault. See Cahn, supra note 1, at 250; see also Ellman \& Lohr, supra note 383, at 724-32 (arguing that the law is a "minor player" in affecting divorce rates and citing studies to demonstrate that divorce laws had 
taining a divorce should not further traumatize children already in emotional upheaval over their parent's break-up. ${ }^{393}$ As Professor Robert Levy, a reporter for the National Conference of Commissioners on Uniform State Laws, stated in a report of the Commission endorsing no-fault divorce in 1965 :

As debilitating as the existing hodgepodge of laws on divorce and marriage may be for the lives of the participants, the destructive effect upon children is incalculable. If the time for improvement and uniformity in this field were not at hand for the sake of the marriage partners, it is surely at hand for the sake of the children. ${ }^{394}$

Although assessments of whether no-fault has achieved the goal of reducing the trauma of divorce for children are mixed, ${ }^{395}$ there has been a shift in the focus in divorce proceedings from an evaluation of the adults' conduct to the children's well-being. This shift is reflected in the many court-related programs that focus on children after divorce that have developed since the adoption of no-fault. ${ }^{396}$

\section{b. Continued Debate About the Morality of Divorce in the No- Fault Era}

The adoption of no-fault divorce did not end discourse and debate about the impact of divorce grounds on commitments undertaken in marriage and the impact of divorce on children. To many commentators, the moral message conveyed by the adoption of no-fault grounds for divorce was that couples can quickly and easily escape commitments of marriage. ${ }^{397}$ While no-fault grounds have made it easier to divorce, it is not clear that the addition of no-fault grounds for divorce signaled a radical

a "weak correlation, if any" to the rise in divorce rates in the 1960s and 1970s); Dirk Johnson, Campaign Aims to Put the "Fault" Back in Divorce: Several States Consider Efforts to Make Marriages Harder to End, Morning News TRIB., Feb. 18, 1996, at G6 (quoting Professor Larry Bumpass, a University of Wisconsin sociologist, as stating that no-fault divorce merely facilitates divorces by speeding up "those cases that were already coming down the pipeline"). Many scholars and commentators argue that no-fault divorce laws were a reflection of other changes that contributed to the rise in the divorce rate more than they were a direct cause of increased divorce. See, e.g., Cahn, supra note 1, at 250-51 (attributing the increase in divorce since the mid 1960s to a number of factors including unhappiness of women in patriarchal marriages and their increased participation in the workforce).

393. See HANDBOOK, supra note 391 , at 181.

394. Id.

395. Compare Wardle, supra note 107 , at $99-103$ (finding that termination of marriage under no-fault regime is still acrimonious) with $\mathrm{JACOB}$, supra note 381, at 151 (discussing the movement leading to no fault divorce and several commentators view's on the effects of those changes).

396. See infra notes $430-43$ and accompanying text.

397. See generally Wardle, supra note 107. 
change in the moral discourse and vision in American divorce law. ${ }^{398}$ Scholars, ${ }^{399}$ legislators, ${ }^{400}$ and social scientists ${ }^{401}$ continue to debate these issues.

A substantial part of the moral discourse about the law's role in divorce has occurred in debates about the wisdom of restoring the emphasis on fault in divorce. Some proposals call for the repeal of no-fault grounds altogether. ${ }^{402}$ One alternative proposal suggests longer waiting periods for divorce everywhere, ${ }^{403}$ while others would allow couples who are getting married to limit themselves to fault-based grounds for di-

398. This Section addresses grounds for divorce or other preconditions specifically tied to the state's grant of a divorce. In marriages involving children or property, resolution of issues of alimony, child custody and support and marital property also continue to act as barriers to divorce. See GLENDON, TRANSFORMATION, supra note 241, at 198-199 (discussing the traditional system's reliance on private agreements "as the principal mechanism for adjusting economic and child-related disputes upon divorce. . . ."). Traditional fault or a broader concept of marital misconduct continues to play a role in these decisions.

399. See supra note 1 and accompanying text; see also Morse, supra note 118, at 605; Swisher, supra note 388, at 270-76. For a response to arguments made against no-fault divorce, see Ellman \& Lohr, supra note 383 , at 719.

400. See Connie Koenenn, Legislatures Move to End No-Fault Divorces, SAN ANTonio ExPRESS-NEws, Mar. 26, 1996 (claiming that Michigan, Idaho, Georgia, Iowa, Virginia, Washington, Minnesota, Illinois, and Pennsylvania are considering laws that will make marriage and divorce more difficult); Russ Pulliam, Real Reform for the Family, InDianapolis News, Feb. 14, 1996, at A8 (discussing proposals to reform the no-fault divorce laws in Indiana); see also H.B. 3751, 18th Leg., Reg. Sess. (Haw. 1995) (proposing a one year waiting period and mandatory pre-divorce counseling for couples with children because "it is often too easy for couples to obtain a 'no-fault' divorce"). Several states are considering bills that would repeal no-fault divorce in certain circumstances. See, e.g., H.B. 1765, 143d Gen. Assembly, Reg. Sess. (Ga. 1995); H.B. 470, 53d Leg., 2d Reg. Sess. (IDBill File, Idaho 1996); S.B. 1842, 89th Gen. Assembly, 1995-96 Reg. Sess. (ILBill File, Ill. 1996); H.B. 911, 1996 Reg. Sess. (KYBill File, Ky. 1996); H.B. 1975, 79th Leg., 1995 Reg. Sess. (Minn. 1995); H.B. 2562, 180th Gen. Assembly, 1995-96 Reg. Sess. (Pa. 1995); H.B. 1188, 1996 Reg. Sess. (Va. 1996); H.B. 2950, 54th Leg., 1996 Reg. Sess. (Wash. 1996); H.B. 4416, 1996 Reg. Sess. (W. Va. 1996). Other states are considering imposing mandatory counseling or other impediments to divorce. See, e.g., H.B. 477, 19th Leg., 2d Reg. Sess. (Alaska 1996); S.B. 2265, 76th Gen. Assembly, Reg. 2d Sess. (lowa 1996) (enacted); S.B. 367, 410th Gen. Assembly 1996 Reg. Sess. (Md. 1996).

401. See, e.g., Colleen leahy Johnson, Ex Famila: Grandparents, Parents, and ChIldren Adjust to Divorce (1988); Barbara Dafoe Whiteriead, THE Divorce Culture (1996); Frank F. Furstenderg, JR. \& ANDrew J. Cherlin, Divided Families: What Happens to ChILDRen When Parents ParT (1991); Paul R. Amato, Children's Adjustment to Divorce: Theories, Hypotheses, and Empirical Support, 55 J. MAR. \& FAM., 23, $23-28$ (1993); R.T. Gill, Family Breakdown as Family Policy, PuB. INT., Winter 1993, at 84.

402. See supra note 400 and accompanying text. Among the many legislative proposals to revise no-fault divorce grounds, Tennessee's proposal to completely eliminate no-fault grounds entirely is the most extreme.

403. See William A. Galston, Divorce American Style, PUB. INT., Summer 1996, at 22 (advocating a 5 year waiting period for all divorces with children.). 
vorce. ${ }^{404} \mathrm{~A}$ number of legal scholars have also pushed for fault to play a more important role in issues attendant to divorce, such as alimony and property distribution. ${ }^{405}$ These proposals are all grounded in the rhetoric of strengthening families and protecting children. ${ }^{406}$

In response to these calls for a broadened role of fault in divorce, some commentators have reexamined the moral bases for no-fault, particularly in cases involving domestic violence. These commentators argue that no-fault divorce is necessary to protect women and children seeking the quickest separation possible from violent spouses..$^{407}$

While this debate has resulted in very little legislative change, ${ }^{408}$ it has provided an opportunity for all participants in the development of family law to rethink the goals, including moral goals, of marriage and commitment. The debate has also lead to more creative thinking about the law's role in strengthening families, particularly families with

404. See supra note 305 and accompanying text.

405. See Swisher, supra note 388, at 296; Morse, supra note 118, at 625.

406. Some commentators have argued that these proposals are more pro-marriage than antidivorce: "I would never call this an anti-divorce movement. It's a marriage movement. The focus is not to punish people who have divorces. It's to tell people that there is this extremely important thing called marriage that needs a lot of support from education, religion, and public policy." Pia Nordlinger, The Anti-Divorce Revolution, WeEkLY STANDARD, Mar. 2, 1998, at 25 (quoting Maggie Gallagher describing the debate about marriage and divorce taking place "across the country, in statehouses and church basements and living rooms").

407. See, e.g., Ellman \& Lohr, supra note 383; see also Frank Furstenberg \& Andrew Cherlin, Longitudinal Studies of Effects of Divorce on Children in Great Britain and the United States, 252 ScI. 1386 (1991) (reporting research findings that demonstrate that while divorce is generally harmful to children, even more harmful is prolonged conflict). But see Kimberle Crenshaw, Mapping the Margins: Intersectionality, Identity Politics, and Violence Against Women of Color, 43 STAN. L. REv. 1241, 1247 (1991) (arguing that immigrant women who are victims of domestic violence and who are threatened with deportation may have difficulty meeting the current requirement that marriage be terminated for good cause if divorce was obtained on no-fault grounds); Martha Heller, supra note 200 , at 282 (evaluating the impact of recent movement to reinstate fault-based divorce has on domestic violence and finding fault-based systems would be a further obstacle to victims' attempts to divorce).

408. See NCSL, supra note 305 . In one state, the effort to protect battered women and children through more effective divorce grounds led to the addition of a new fault ground in the state's divorce law. Because Maryland only permitted divorce without a waiting period in cases of adultery, sponsors argued, on moral grounds, that battered women were entiled to the same protection as spouses experiencing infidelity. As Lieutenant Governor Kathleen Kennedy Townsend argued before the legislature, "We cannot continue to tell women ... that when their husbands sleep with someone else, they can file immediately for divorce, but when they beat them up or even rape them, that they have to stay in the marriage for another year." Jane C. Murphy, Assembly Bill to Speed Divorce After Abuse Will Save Many Lives, Bring Needed Reform, BALT. Sun, Feb. 24, 1998, at A14. The bill adding abuse grounds passed in April, 1998. See MD. CODE ANN. FAM. LAw \$ 7-103(a)(7-8) (Supp. 1998). 
children. ${ }^{409}$

\section{Protecting Children: Changes in Custody and Visitation Law}

Modern custody law has been dominated by the "best interests of the child" standard. ${ }^{410}$ This ambiguous standard permits judges broad discretion in deciding custody and visitation cases. ${ }^{411}$ This discretion has resulted in inconsistent application of the standard, ${ }^{412}$ gender bias ${ }^{413}$ and expensive, lengthy custody proceedings. ${ }^{414}$ However, several developments over the last decade indicate that courts and legislatures are attempting to refine this standard and curb judicial discretion in ways that focus more directly on the welfare of the child. Additionally, several recent developments in custody law are intended to increase the involvement of both parents. Both the debate surrounding these developments and the new laws themselves reflect a commitment to the central moral goal of family

409. The recent debate among social science and legal scholars about marriage and divorce has also encouraged new, non-partisan research efforts aimed at understanding the impact of both those events on children. Leaders in both the American Bar Association and the American Psychological Association approved a proposal to establish "a university-based research center to provide more thorough and objective information on marriage and divorce." Lynn Smith, Giving Context to Issues '90s Families Face Values: Tired of What it Calls Politically Charged and Simplistic Solutions to Societal Woes, a New Group Tries a Fresh Approach, L.A. TIMES, Nov. 12, 1997, at E1.

410. The Uniform Marriage and Divorce Act, which provides the best summary of prevailing standards, states:

$\S 402$. [Best Interest of Child]

The court shall determine custody in accordance with the best interest of the child. The court shall consider all relevant factors including:

(1) the wishes of the child's parent or parents as to his custody;

(2) the wishes of the child as to his custodian;

(3) the interaction and interrelationship of the child with his parent or parents, his sib-

lings, and any other person who may significantly affect the child's best interest;

(4) the child's adjustment to his home, school, and community; and

(5) the mental and physical health of all individuals involved.

The court shall not consider conduct of a proposed custodian that does not affect his relationship to the child.

UNIF. MARRIAGE AND DivorCe ACT, § 402, 9A U.L.A. 282 (1998).

411. See discussion infra at 128-139; see also Reidy et al., Child Custody Decisions: A Survey of Judges, 23 FAM. L.Q. 75 (1989) ("What is 'in the best interests of child(ren)' is often a complex balancing of numerous competing factors, many of which are highly subjective.").

412. See Richard Neely, The Divorce Decision: The legal and human Consequences of ENDING A MARRIAGE 9-10 (1984).

413. See Susan Beth Jacobs, The Hidden Gender Bias Behind "The Best Interest of the Child" Standard in Custody Decisions, 13 GA. ST. U. L. REv. 845-901 (1997).

414. See, e.g., Murphy, supra note 386 , at 127-30 (describing the complexities of what should be a rather simple divorce); NeELY, supra note 412 , at 93-118. 
law, protecting children. ${ }^{415}$ While some of these developments have resulted in fewer explicit references to "moral conduct" in custody decisions, overall the trend toward more child-centered custody law has strengthened the law's commitment to nurturing children. ${ }^{416}$

\section{a. Developments Encouraging Post Breakup Involvement of} Both Parents

\section{i. Joint Custody}

The addition of no-fault concepts in laws in the 1970s included marked shifts in custody law that were intended to encourage the participation of both parents in raising children. ${ }^{417}$ One of the first developments of this kind was the introduction of the concept of joint custody. The first joint custody statute was passed in 1979 in California ${ }^{418}$ and most states eventually followed suit, either by joint custody statutes or through case law. ${ }^{419}$ While the legislative history surrounding the adoption of these statutes reflects a concern for parents' right to have access to their children, ${ }^{420}$ the primary purpose of these statutes seems to be to benefit children. ${ }^{421}$

415. See supra notes $73-85$ and accompanying text.

416. See, e.g., Scott Coltrane \& Neal Hickman, The Rhetoric of Rights and Needs: Moral Discourse in the Reform of Child Custody and Child Support Laws, 39 Soc. PROBS. 400, 404 (1992) (discussing the role of father's groups and mother's groups in shaping the laws).

417. See, e.g., EllMAN ET AL,, supra note 232, at 666 (describing the joint custody trend as reflecting "an underlying policy of encouraging both parents to maintain their relationship with the child after divorce").

418. See CAL CIV. CodE 4600.5 (Deering 1984) (repealed 1981).

419. As of 1996,43 states and the District of Columbia had statutes that specifically authorize the courts to order joint custody. In some states, joint custody is referred to as shared custody. In the 43 states with joint legal custody statutes, 11 states and the District of Columbia declare a presumption in favor of joint custody, which means that courts are supposed to grant joint custody unless there is proof that joint custody is not in the child's best interest. Eight states declare a presumption in favor of joint custody if both parents agree to it. The remaining 24 states with joint custody statutes make joint custody an explicit option without any presumption for or against joint custody. Seven states do not have joint custody statutes, but courts in those states can use their equitable powers to order joint custody in appropriate circumstances. Joint custody usually is considered appropriate when parents appear willing to cooperate in raising their children. See Jeff Atkinson, Modern Child Custody Practice, sec. 6.01 in AMERICAN BAR AssociatIon's Facts ABour CHILDREN AND THE LAW (1996).

420. See Legislative History of CAL. FAM. CODE $\S 3080$.

421. See Taylor v. Taylor, 508 A.2d 964, 969-70 (Md. 1986) (discussing the equitable powers of Maryland courts to enter joint custody orders, and observing that "the power of the court is very broad so that it may accomplish the paramount purpose of securing the welfare and promoting the best interest of the child"). 
The impact of joint custody statutes on the welfare of children has been mixed. ${ }^{422}$ Many commentators and researchers have concluded that joint custody promotes the welfare of children. ${ }^{423}$ Others argue that joint custody should be reserved for low conflict, high resource couples. ${ }^{424}$ However, in the years since the adoption of the first statute in California, joint custody laws have been refined in a variety of ways to further the goal of providing children with the benefit of both parents' care. These changes include permitting joint custody only in cases where parents have agreed to such an arrangement. ${ }^{425}$ Additionally, eleven states either prohibit joint custody when a court finds that there has been domestic violence or direct the courts to consider violence as a factor that weighs against an award of joint custody. ${ }^{426}$ These statutory provisions are consistent with social science and legal scholarship, which have found that children living under joint custody orders in high conflict families have more emotional and behavioral problems than those in sole custody. ${ }_{4} 27$

\section{ii. Parenting Classes and Parenting Plans}

Another development over the last decade that has promoted involvement of both parents in children's lives when parents live apart is the growing use of "parenting classes" and "parenting plans." 428 While

422. See generally Joint Custody And Shared Parenting (Jay Folberg ed., 1991) thereinafter JoINr CUSTODY] (presenting various writings on child development relating to joint custody).

423. See Ross A. Thompson, The Role of the Father After Divorce, in CHILDREN OF DivorCE, at 210, 211 (examining the effects of custody laws, among other factors, on post divorce parenting role for fathers and noting that the most important reason for considering father's role is "to advance the welfare of the child").

424. See, e.g., Richard Gardner, Joint Custody is not for Everyone, in JoINT Custody, supra note 422 , at 66 .

425. See Cal. Fam. Code $\S 3080$ (West 1994); Conn. Gen. Stat. Ann. $\S \S 46 b-56 a(b)$ (West 1995); Me. Rev. Stat. AnN. tit. 19, § 214(6) (West Supp. 1996); Mich. Comp. Laws Ann. $\S 722.26$ (2) (West 1993); Nev. Rev. Stat. ANN. $\$ 125.490(1)$ (Michie 1993); N.H. Rev. Stat. ANN. § 458:17(II) (1992).

426. See Arz. Rev. Stat. Ann. § 25-332 (West 1994); Colo. Rev. Stat. AnN. § 14-10-124 (West 1994); Fla. Stat. ANN. § 61.13 (West 1995); Idaho Code $\$ 32-717$ (1994); 750 ILL. Comp. Stat. 5/602 (West 1994); MoNT. Code ANN. §§ 40-4-212, 222, 224 (1993); N.H. Rev. Stat. ANN. § 458:17 (1993); N.D. CENT. CODE § 14-09-06.2 (1993); R.I. GEN. LAwS § 15-5-16 (1994); TEX. FAM. Code ANN. $\$ 14.021$ (West 1994); Wyo. Stat. ANN. \$\$ 20-2-112 to 113 (Michie 1994).

427. See Janet R. Johnston et al., Ongoing Post Divorce Conflict: Effects on Children of Joint Custody and Frequent Access, 59 AMER. J. ORTHOPSYCHIATRY 576 (1989); see also Judith S. Wallerstein \& Janet R. Johnston, Children of Divorce: Recent Findings Regarding Long-Term Effects and Recent Studies of Joint and Sole Custody, 11 Pediatrics IN REv. 197 (1990).

428. AFCC Directory OF PARENT EduCATION Programs (1996) [hereinafter AFCC DirecTORY] (providing brief program descriptions and contact people); see also Peter Salem et al., Special Issue: Parent Education in Divorce and Separation, 34 FAM. \& Conciliation Rev. No. 1 (Jan. 1996) 
the format and content vary, ${ }^{429}$ the primary focus of most court-affiliated parent education programs is easing the family transition for children. ${ }^{430}$ Mental health professionals, and in some cases lawyers, team together to teach parents techniques to improve parental cooperation and other skills designed to minimize the negative impact of divorce on children..$^{431}$ Early reports indicate a positive impact on children. ${ }^{432}$ Over 40 states now offer families experiencing divorce or separation educational programs to assist parents to better care for their children. ${ }^{433}$ Laws in at least thirteen states authorize courts to order divorcing parties to participate in such programs, and three states mandate that all parties to a divorce case with children participate in parent education. ${ }^{434}$

Parenting plans are another feature of recent custody law that courts and legislatures have introduced to protect children involved in custody disputes by promoting the involvement of both parents in their children's lives. ${ }^{435}$ Parenting plans typically delineate each parent's responsibilities

(containing essays and research reports on parent education programs throughout the country).

429. In some jurisdictions, parents do not attend the same session; in others, they are expected to attend together. However, most states offer spouses the option of attending separately. Some programs include information on the legal process, while others focus solely on emotional issues. Programs operate in courthouses as well as community centers, universities, churches, and synagogues.

Andrew Schepard et al., The Push for Parent Education, 19 FAM. Advoc., Spring 1997, at 52, 54.

430. See, e.g., Andrew Schepard \& Stephen W. Schlissel, Planning for P.E.A.C.E.: The Development of Court-Connected Education Programs for Divorcing and Separating Families, 23 HoFSTRA L. REV. 845, 851 (1995) (noting that parents report that participation in the planning program helps them to focus on the best interests of their children during the reorganization of their family and that they receive information and perspective that will help their children cope with the difficult transitions of divorce).

431. See AFCC DIRECTORY, supra note 428.

432. See Salem et al., supra note 428 , at 13-14.

433. See Schepard et al., supra note 429 , at 53 .

434. See id.

435. See Elizabeth R. Kosier, Mediation in Nebraska: An Innovative Past, a Spirited Present, and a Provocative Future, 31 CReiGHTON L. Rev. 183, 195 (1997) (discussing Nebraska's Parenting Act, which supplements and extends legislative support for mediation in the area of domestic relations following legislative findings that joint parental decision-making is in the best interest of minor children experiencing divorce or separation and mandates district court distribution of information regarding parenting plan mediation and encourages the use of mediation for the development of a parenting plan); Deborah Maranville, Theoretics of Practice: The Integration of Progressive Thought and Action: Feminist Theory and Legal Practice: A Case Study on Unemployment Compensation Benefits and the Male Norm, 43 HASTINGS LJ. 1081, 1089 (1992) (noting the Washington legislature's rejection of conventional custody/visitation terminology for proceedings involving parental access to their children in favor of the phrase "residential time" and a procedure involving the preparation of "parenting plans"); Andrew Schepard, Taking Children Seriously: Promoting Cooperative Custody Afier Divorce, 64 TEx. L. REv. 687, 691 (1985) (urging that the state must promote cooperative parenting through its procedures for dispute resolution, by creating an atmosphere for negotia- 
for the care of the children and decisions about education, health care, discipline and education. ${ }^{436}$ They also describe visitation times or, if applicable, joint physical custody. These plans also make provisions for resolving future disputes. ${ }^{437}$ About ten states and the District of Columbia currently require parties to submit proposed parenting plans prior to a grant of custody. Another eight states have statutes that give judges discretion to require parenting plans in custody cases. ${ }^{438}$

While many plans written under these statutes will result in more private ordering child placement decisions after divorce, these statutes

tion that encourages both parents to make concessions to ensure that the other parent is involved in the child's post divorce emotional and financial life).

436. See Don R. Ash, Adoption and Custody: Current Trends in Tennessee Family Law: Bridge Over Troubled Water: Changing the Custody Law in Tennessee, 22 MeMPHS ST. L. REv. 769, 804-05 (1997) (suggesting parenting plans should be divided into five different sections, including: (1) the time a child is with the parent overnight with the parent at home; (2) the actual time the parent and the child spend together, (3) the portion of the time the child and the parent spend in recreation or projects together or activity time; (4) how the parents will work together to make day-to-day decisions, which would include, for example, discipline, curfew, allowances, health care habits, and other short term activities; and (5) how the parents will make major decisions about such things as education, religious affiliation, critical or long-term medical care, and for older children, sports, the purchase of cars, and decisions about college); Margaret Martin Barry, The District of Columbia's Joint Custody Presumption: Misplaced Blame and Simplistic Solutions, 46 CATH. U.L. REV. 767, 793 (1997) (citing Arizona's parenting plan statute as a good example of what these plans should delineate: (1) each parent's rights and responsibilities for the personal care of the child and for decisions in areas such as education, health care, and religious training; (2) a schedule of the physical residence of the child, including holidays and school vacations; (3) a procedure by which proposed changes, disputes and alleged breaches may be mediated or resolved, which may include the use of conciliation services or private counseling; (4) a procedure for periodic review of the plan's terms by the parents; and (5) a statement that the parties understand that joint custody does not necessarily mean equal parenting time).

437. See supra note 436 and accompanying text; see also Jane W. Ellis, Plans, Protections, and Professional Intervention: Innovations in Divorce Custody Reform and the Role of Legal Professionals, 24 Mich. J.L. REF. 65, 107-08 (1990) (discussing Washington's statutory requirements that the parenting plan must specify terms with respect to three discrete components: a dispute resolution process; allocation of decision-making authority; and residential provisions for given days of the year, including a provision for holidays, birthdays, vacations, and other special occasions).

438. See Ala. Code 30-3-153 (1995); ARIZ. Rev. Stat. ANN. § 25-403(I) (West Supp. 1996); D.C. Code ANn. § 16-911(a-2)(2)(A) (Supp. 1996); 750 Ill. Comp. Stat. ANn. 5/602.1 (West Supp. 1996); MASs. GEN. LAws ANN. ch. 208, $\S 31$ (West Supp. 1996) ("At the trial on the merits, if . . either party seeks shared legal or physical custody, the parties, jointly or individually, shall submit . . . a shared custody implementation plan."); Mo. ANN. STAT. § 452.375(8) (West Supp. 1997) ("Any decree providing for joint custody shall include a specific written plan setting forth the terms of such custody. Such plan may be suggested by both parents acting in concert, or one parent acting individually, or if neither . . . the plan shall be provided by the court."); MONT. CODE ANN. $\S 40-4$ 223(b)(2) (1995); N.M. Stat. ANN. § 40-4-9.1(F) (Michie 1996); OKLA. StaT. ANN. tit. 43, § 109(C) (West 1990); WASH. Rev. CODE ANN. \$ 26.09.181 (West Supp. 1996) ("In any proceeding . . . each party shall file and serve a proposed permanent parenting plan."). But see DEL. CODE ANN. tit. 13, $\S 727$ (1993). 
give courts authority to require parents to focus on the care of their children. This shifts the emphasis in divorce and custody cases from the adults to the children. ${ }^{439}$ Again, there is evidence that the use of parenting plans has begun to accomplish the goal of minimizing the negative impact that parents living apart has on children. ${ }^{440}$

\section{b. The Child's Voice in Custody Proceedings}

Another development that has reinforced the focus on children in custody disputes is the trend toward increased emphasis on the "child's voice" in custody proceedings. ${ }^{441}$ This has been accomplished, in part, by greater use of appointed attorneys for children in custody cases. ${ }^{442}$ While appointment of counsel is still discretionary in most states, ${ }^{443}$ appellate courts have increasingly emphasized the need to have the child's voice heard in some way. ${ }^{444}$ As one court put it:

439. See Ash, supra note 436 , at 805 (noting that the advantage of a mediator in the parenting plan process is that he or she can help parents focus on making the children a priority, and also stress the importance to parents of maintaining an ongoing relationship with one another for the benefit of the children); Ellis, supra note 437, at 88-89 (explaining that requiring parents in all cases to use a plan with specific components is intended to refocus parental consciousness on the needs of their children).

440. See Lynne M. Kenney \& Diana Vigil, A Lawyer's Guide to Therapeutic Interventions in Domestic Relations Court, 28 ARIz. ST. LJ. 629, 645 (1996) (stating that when parents are in disagreement over matters concerning the child, parenting plans can help them reach an agreement). But see Jane W. Ellis, Caught in the Middle: Protecting Children of High Conflict Divorce, 22 N.Y.U. REv. L. \& Soc. CHANGE 253, 261 \& n.48 (explaining that the parenting plan sometimes exacerbates the conflict between parents rather than lessening it).

441. See Katherine Hunt Federle, Looking for Rights in all the Wrong Places: Resolving Custody Disputes in Divorce Proceedings, 15 CARDozo L. Rev. 1523, 1563 (1994) (suggesting that under a strong version of rights, hearing a child's voice and giving her input would ameliorate the negative consequences of bargaining over custody and reduce animosity between the spouses who would need to confront the effects of their behavior on the child); Gilbert A. Holmes, The Extended Family System in the Black Community: A Child-Centered Model for Adoption Policy, 68 TEMP. L. REv. 1649, 1671-72 (1995) (noting that commentators have attempted to refine the child-centered approach into a doctrine that would support a greater recognition of children's rights and voices in custody disputes, and advocating an approach that listens to the child's voice, includes the child's experiences and values, and tames the adult "rights talk" by viewing children's needs both as children and as the adults they become); Jane M. Spinak, Reflections on a Case (of Motherhood), 95 CoLuM. L. REv. 1990, 2035 (1995) (noting that in the continuing debate about the role of the child in decision making about that child's life, the question of the child's voice is a persistent theme and at the center of a legal controversy over the child's custody and care, the adults involved all struggle to determine how much "voice" the child should possess).

442. See Linda D. Elrod \& Robert G. Spector, A Review of the Year in Family Law: A Search for Definitions and Policy, 31 Fam. L.Q. 613, 628 (1998).

443. Only one state mandates such representation in contested cases. See Wis. Stat. ANn. $\S 767.045$ (West 1993 \& Supp. 1996).

444. See, e.g., Levitt v. Levitt, 79 Md. App. 394, 404-405 (1989) (remanding the case with in- 
We are most concerned that a five-year-old child has been the subject of litigation for over one-fourth of his life and has yet to see an end to it. We are also concemed that during the four days of testimony before the Master, the Master never spoke to the child, never heard from a truly objective witness and did not have the input of someone who would speak on behalf of the child. Since no other testimony was offered, the hearing before the Chancellor suffered from the same deficiency. This deficiency should be remedied by our direction that separate counsel be appointed for [the child]. ${ }^{445}$

Advocates and scholars have encouraged this trend of requiring counsel for children in custody cases by identifying the benefits to children of having representation ${ }^{446}$ and developing standards to improve the effectiveness of such representation. ${ }^{447}$

\section{c. Refining the Best Interest Standard}

\section{i. The Nexus Requirement in Determining Parental Fitness}

The focus of moral discourse in custody cases during the fault era was on parents' sexual conduct. In the last decade, courts have moved from rules that presumptively disqualify parents who engage in nonmarital sexual relationships ${ }^{448}$ to a standard that requires a "nexus" or connection between any challenged conduct and harm to the child before considering such conduct relevant. ${ }^{449}$ While decisions applying the nexus

structions that an attomey be appointed to represent the interests of the five-year-old child whose custody was at stake, although no one had sought the appointment of counsel for the child at the trial court level); see also Grist v. Grist, 946 S.W.2d 780 (Mo. Ct. App. 1997) (stating that if there are allegations of abuse, the trial court must appoint a guardian ad litem for the child).

445. Levitt, $79 \mathrm{Md}$. App. at 404-05. Courts have also held that children in custody disputes should be permitted to dismiss an attorney and retain counsel of his or her choice. See ArEen, supra note 240 , at 77 .

446. See Howard A. Davidson, The Child's Right to Be Heard and Represented in Judicial Proceedings, 18 PEPP. L. Rev. 255, 269-70 (1991); see also Linda Elrod, Counsel for the Child in Custody Disputes: The Time is Now, 26 FAM. L.Q. 53, 63 (1992); Emile R. Kruzick \& David H. Zemans, In the Best Interests of the Child: Mandatory Independent Representation, 69 DENv. U.L. Rev. 605 (1992). But see JOSEPH Goldsten ET AL., BEFORE THE BEST INTERESTS OF THE CHILD 119 (1979) (arguing that generally, parents should decide whether their child needs legal representation).

447. See Tara Lea Muhlhauser, From "Best" to "Better": The Interests of Children and the Role of a Guardian Ad Litem, 66 N.D. L. REV. 633 (1990); see also Robert E. Shepherd, Jr. \& Sharon S. England, "I Know the Child Is My Client, But Who Am I?," 64 FordHAM L. Rev. 1917, 1941-42 (1996); David Peterson, Comment, Judicial Discretion Is Insufficient: Minors' Due Process Right to Participate with Counsel When Divorce Custody Disputes Involve Allegations of Child Abuse, 25 Golden Gate U. L. Rev. 513 (1995).

448. See supra notes $210-38$ and accompanying text.

449. See 2 John P. McCahey et al., Child Custody and Visitation law and Practice $\$ 10.12$ [2][b], 10-212-213 (1996) ("The court shall not consider conduct of a proposed custodian that does not affect his relationship to the child.") Some fault-era cases did apply a nexus standard, 
requirement may make fewer explicit references to morality, such a requirement places a greater emphasis on child welfare and less emphasis on punishing parents. It is that emphasis on child welfare that supports the moral vision in family law more directly than the punishment of sexually active parents.

One of the earliest cases marking the trend toward the harm requirement where a parent's sexual behavior was challenged was the New York case of Feldman v. Feldman. ${ }^{450}$ In Feldman, the trial court transferred custody of two children from the mother to the father because of the mother's "desire to experiment sexually." 451 The appellate court reversed stating:

In my opinion, amorality, immorality, sexual deviation and what we conveniently consider aberrant sexual practices do not ipso facto constitute unfitness for custody. ... In the instant case our sole concem is for the best interests of the children. As both children have resided with the mother since birth, a change of custody at this late date should not be made unless there is a showing that she is unfit to continue as the custodial parent. ... ${ }^{452}$

Since 1975 , many states have moved from a standard focused on punishing the "guilty party" 453 to a standard that makes "an honest attempt to evaluate what would be in the best interest of the child rather than on the basis of subjective reactions to parental moral values." 454

but these discussions represented the minority view at that time. See, e.g., McAnespie v. McAnespie, 200 So. $2 d$ 606, 609 (Fla. Dist. Ct. 1957) ("The moral unfitmess of a mother must be such as has a direct bearing on the welfare of the child, if it is to deprive her of the custody of the child."); Reiland v. Reiland, 160 N.W.2d 30, 32-33 (Minn. 1968) ("The fact that the mother has been indiscrete or unfaithful does not necessarily disqualify her as custodian of the children. The moral unfitness of the mother must be such as to have a direct bearing on the welfare of the child if she is to be deprived of custody."). Likewise, some contemporary decisions still consider involvement in nonmarital sexual conduct as evidence of unfitness. See, e.g., Dockins v. Dockins, 475 So. 2d 571, 573 (Ala. Civ. App. 1985) (mother denied custody for entertaining lover in her home once while children were present).

450. 358 N.Y.S.2d 507, 511-12 (N.Y. App. Div. 1974).

451. Id. at 509-10.

452. Id. at 512 (citations omitted); see also Davis v. Davis, 372 A.2d 231, 235 (Md. 1977) ("[W] hereas the fact of adultery may be a relevant consideration in child custody awards, no presumption of unfitness on the part of the adulterous parent arises from it; rather it should be weighed along with all other pertinent factors, only insofar as it affects the child's welfare.").

453. See Beck v. Beck, 120 N.W.2d 585, 589 (Neb. 1963).

454. Nora Lauerman, Non-Marital Sexual Conduct and Child Custody, 46 CiN. L. Rev. 647, 672,681 (1977) (noting the variety of approaches courts were taking in the 1970s in custody cases involving non-marital sexual conduct and finding cases that require a "clear direct impact" of harm to the child as a result of the sexual misconduct the "soundest"). For modem cases reflecting this trend see, e.g., Hanhart v. Hanhart, 501 N.W.2d 776, 778 (S.D. 1993) (awarding custody to mother was in child's best interests despite mother's adulterous affair, where affair had no detrimental im- 
Courts still are fairly consistent in labeling both mothers and fathers actively engaged in homosexual relationships as poor moral examples for their children. ${ }^{455}$. However, recent custody decisions have also begun to require a demonstrated nexus between harm to the child and the parent's sexual orientation. ${ }^{456}$ These decisions signal a trend away from custody decisions that place primary emphasis on punishing parents for sexual activity rather than focusing on arrangements that will best serve children.

\section{ii. Primary Caretaker Standard}

Another development in custody that has refined the best interests test is the emphasis on the primary caretaker in custody decisions. ${ }^{457}$ The primary caretaker can be defined as the parent who has been most involved in providing day-to-day care, such as preparing meals, purchasing clothes, arranging for medical care, education, and social activities, putting the child to bed at night, and waking the child in the morning. ${ }^{458}$

pact on children); Kenneth L.W. v. Tamyra S.W., 408 S.E.2d 625, 628 (W. Va. 1991) (holding that adulterous behavior of mother could not be used to rebut primary caretaker presumption; and granting mother custody); Stacy v. Stacy, 332 S.E.2d 260, 262 (W. Va. 1985) (stating that acts of sexual misconduct by a mother may not be considered as evidence of fitness for custody unless it is injurious to the children).

455. The majority of state courts still suggest that a parent's homosexuality is a negative factor in the best interest analysis. See Linda D. Elrod, Family Law in the Fifty States 1994-1995: Case Digests, 29 FAM. L.Q. 775, 810-11 (1996).

456. See, e.g., DeLong v. DeLong, No. 52726, 1998 WL 15536, at*6, *11 (Mo. Ct. App. W. Dist., Jan. 20, 1998) (noting that Missouri trial courts appear to have adopted a per se rule in awarding custody to heterosexual parents when the other parent is homosexual, the court held that focusing a custody decision on a parent's sexual preference, without assessing either parents' fitness and relationship to the child, is not in the child's best interest); Blew v. Verta, 617 A.2d 31, 36, 37 (Pa. Super. Ct. 1992) (overtuming a lower court order prohibiting a lesbian mother from visiting her son in the presence of her female companion).

457. See generally Phyllis T. Bookspan, From a Tender Presumption to a Primary Parent Presumption: Has Anything Really Changed? . . Should It?, 8 BYU J. PuB. L. 75-84 (1993) (citing a 1982 study of appellate court decisions that "found the idea of primary caretaker increasingly popular in determining custody disputes").

458. See Garska v. McCoy, 278 S.E.2d 357, 363 (W. Va. 1981). Garska has been modified by recent statutory changes in West Virginia that continue to instruct judges to allocate custodial responsibility for children based upon past caretaking responsibilities, but do not create a presumption in favor of the primary caretaker. See W. VA. CODE $\$ \$ 48-11-101$ to 48-11-501 (Supp. 1999). For a full discussion of the merits of the primary caretaker rule, see David L. Chambers, Rethinking the Substantive Rules for Custody Disputes in Divorce, 83 MicH. L. Rev. 477, 527-38 (1984) (recommending a rule favoring the primary caretaker for children five and under); see also Richard Neely, The Primary Caretaker Parent Rule: Child Custody and the Dynamics of Greed, 3 YAle L. \& PoL'Y Rev. $168,180-82$ (1984) (arguing for a presumptive rule in favor of the primary caretaker). This rule is not necessarily inconsistent with the trend toward involvement of both parents after divorce. In families where parents shared the caretaking responsibilities equally during the marriage, joint custody would be appropriate upon divorce. See id. at 184 . One scholar has proposed a refinement of the pri- 
This increased emphasis on the primary caretaker has been reflected in cases that apply a best interest standard but place special importance on the primary caretaker as one of many factors to be taken into account in the custody decision. ${ }^{459} \mathrm{~A}$ few states have adopted a rule that presumes that the primary caretaker will have custody unless that parent is unfit or, in some cases, an older child's preference will prevail. ${ }^{460}$ Advocates of the primary caretaker rule have long argued that it best advances the virtues of certainty and predictability while furthering the goal of producing decisions in the best interests of the child. ${ }^{461}$ An increasing number of states have incorporated this concept into their custody law. ${ }^{462}$ In applying the primary caretaker rule, decisionmakers look to past behavior rather than attempting to predict future behavior. ${ }^{463}$ Judges base decisions on the reasonable assumption that the interests of a child are best served by preserving the relationship that has been the primary source of nurturing and care. ${ }^{464}$

mary caretaker standard that would take into account an expanded role for the non-custodial parent. Elizabeth Scott has proposed the "approximation" rule in which the decisionmaker "focuses (almost) exclusively on the past relationship between parents and child and seeks to approximate as closely as possible the predivorce pattern of parental responsibility in the custody arrangement." Elizabeth S. Scoth, Pluralism, Parental Preference, and Child Custody, 80 CAL. L. Rev. 615, 630 (1992). This approach is aimed at responding to two areas of concern about the child's welfareminimizing trauma of family breakup and maximizing involvement of both parents in child's life. See id.

459. See generally Bookspan, supra note 457 , at 84 .

460. See, e.g., Garska, 278 S.E.2d at 363; see also In re Maxwell, 456 N.E.2d 1218, 1222 (Ohio Ct. App. 1982).

461. See Chambers, supra note 458, at 527-38; see also Neely, supra note 458, at $185-86$; Nancy D. Polikoff, Why Are Mothers Losing: A Brief Analysis of Criteria Used in Child Custody Determinations, 7 WoMEN's RTs. L. REP. 235, 241-43 (1982). But see Mary V. Becker, Maternal Feelings: Myth, Taboo, and Child Custody, 1 S. CaL. Rev. L. \& Women's Stud. 133, $154-58$ (analyzing decisions under the primary caretaker standard and finding that it hurts mothers).

462. See, e.g., Maxfield v. Maxfield, 452 N.W.2d 219, 223 (Minn. 1990) ("[T]he golden thread running through any best interests analysis is the importance ... . of [a child's] bond with the primary parent. ..."); Maxwell, 456 N.E.2d at 1222 (affirming custody award to mother because she was the primary caretaker, although both parents were fit); In re Boldt, 801 P.2d 874, 875 (Or. Ct. App. 1990) (affirming custody award to mother because she had been the primary caretaker); Garska, 278 S.E.2d at 364 (awarding custody to the mother, because she was clearly the primary caretaker before the proceedings).

463. See Neely, supra note 458 , at $180-82$.

464. See Maxfield, 452 N.E.2d at 223. After its adoption in Pikula v. Pikula, 374 N.W.2d 705, 713 (Minn. 1985), the Minnesota Legislature rejected the primary caretaker presumption and restored the best interest standard. See MinN. Stat. § 518.17 (1998); see also Gary Crippen, Stumbling Beyond Best Interests of the Child: Re-examining Child Custody Standard-Setting in the Wake of Minnesota's Four Year Experiment with the Primary Caretaker Preference, 75 MiNN. L. Rev. 427, 42829 (1990) (concluding Minnesota courts continue to place strong emphasis on the primary caretaker as a factor in the best interest equation). 
Social science research emphasizing the link between the primary caretaker's emotional and economic well-being and the well-being of children ${ }^{465}$ has also begun to change the focus from parents' right to have access to their children to a greater emphasis on children's welfare in custody "relocation" cases. ${ }^{466}$ These cases involve custody modification requests, which are triggered when a custodial parent attempts to relocate and, in so doing, increases the distance between the children and the noncustodial parent. ${ }^{467}$ In the past decade, an increasing number of courts and legislatures have placed restrictions on such moves on a variety of grounds, including protection of rights of noncustodial parents. ${ }^{468} \mathrm{Re}$ search has demonstrated that children's interests are served by supporting the custodial parent even where it interferes with the non-custodial parent's desire for more frequent visitation. ${ }^{469}$ This research has begun to reverse the trend of modifying custody when the custodial parent relocates. ${ }^{40}$ Appellate courts from a wide variety of states have signalled to trial courts that protection of the custodial family unit should take precedence over deference to the noncustodial parent's rights. ${ }^{471}$

465. See, e.g., Carol S. Bruch \& Janet M. Bowermaster, The Relocation of Children and Custodial Parents: Public Policy, Past and Present, 30 FAM. L.Q. 245, 263-64 (1996) ("[T] importance of the primary relationship has been convincingly demonstrated, while no similar support has been found for the visiting relationship.").

466. See Cheryl S. Karner, Relocation: What Ought to Be, 20 FAM. L.Q. 12 (1997).

467. See id.

468. See, e.g., Auge v. Auge, 334 N.W.2d 393, 397 (Minn. 1983) (finding that the limited purpose of a statute requiring notice to a noncustodial parent before a custodial parent makes a substantial move is "to safeguard the visitation rights of the noncustodial parent"); see also In re Marriage of Elser, 895 P.2d 619, 622-23 (Mont. 1995) (focusing exclusively on the disruption of the father's visitation that would result if the custodial mother were allowed to remove the couple's children from the state so that she could further her education), overruled in part by Porter v. Galarneau, 911 P.2d 1143, 1150 (Mont. 1996); Holder v. Polanski, 544 A.2d 852, 854-55 (N.J. 1988) (finding that the purpose of the New Jersey removal statute "is to preserve the rights of the noncustodial parent and the child to maintain and develop their familial relationship").

469. See, e.g., Furstenderg \& ChERLIN, supra note 401, at 107-108; see also Valarie King, Nonresident Father Involvement and Child Well-Being: Can Dads Make a Difference?, 15 J. FAM. Issues 78 (1994); see also Judith S. Wallerstein \& Tony J. Tanke, To Move or Not to Move: Psychological and Legal Considerations in the Relocation of Children Following Divorce, 30 FAM. L.Q. 305, 311-14 (1996).

470. See FURSTENBERG \& CherLIN, supra note 401, at 107-08.

471. See, e.g., Vachon v. Pugliese, 931 P.2d 371, 376 (Alaska 1996); In re Marriage of Burgess, 913 P.2d 473, 478 (Cal. 1996); In re Marriage of Francis, 919 P.2d 776, 784 (Colo. 1996); Mize v. Mize, 621 So. 2d 417, 419-20 (Fla. 1993); Lamb v. Wenning, 600 N.E.2d 96, 98-99 (Ind. 1992); Silbaugh v. Silbaugh, 543 N.W.2d 639, 641 (Minn. 1996); Bell v. Bell, 572 So. 2d 841, 847 (Miss. 1990); In re Marriage of Hogstad, 914 P.2d 584, 587 (Mont. 1996); Harder v. Harder, 524 N.W.2d 325, 328 (Neb. 1994); Trent v. Trent, 890 P.2d 1309, 1312 (Nev. 1995); Holder v. Polanski, 544 A.2d 852, 856 (N.J. 1988); Tropea v. Tropea, 665 N.E.2d 145, 151 (N.Y. 1996); Stout v. Stout, 560 N.W.2d 903, 906 (N.D. 1997); Fossum v. Fossum, 545 N.W.2d 828, 832 (S.D. 1996); Fortin v. 


\section{iii. Recognizing the Connection Between Domestic Violence} and Parental Fitness

Over the last two decades, courts and legislators have begun to discover the connection between domestic violence and "best interests" of children in custody cases. ${ }^{472}$ Twenty years ago, judges routinely excluded evidence of a parent's abusive behavior toward another adult in the household because it was thought that such abuse was not relevant to a parent's fitness for custody. ${ }^{473}$ Advocates, supported by research demonstrating the connections between domestic violence and child abuse, began petitioning state legislatures to permit or require judges to consider domestic violence when determining custody or visitation. ${ }^{474}$ Statutes permitting judges to consider spousal abuse as relevant to fitness began appearing in the 1980 s. $^{475}$ In 1990 , only about sixteen states had such statutes. ${ }^{476}$ As of 1995, forty-four states and the District of Columbia had amended their custody statutes to include some provision that alerts judges to the danger spouse abusers pose to children. ${ }^{477}$ These provisions generally either (1) permit or require courts to consider the occurrence of domestic violence between parents as one of several factors relevant to determining the best interests of the child; or (2) create a presumption against an award of custody to a parent who has demonstrated a pattern

Fortin, 500 N.W.2d 229, 231 (S.D. 1993); Aaby v. Strange, 924 S.W.2d 623, 629 (Tenn. 1996); Lane v. Schenck, 614 A.2d 786, 791 (Vt. 1992); Bohms v. Bohms, 424 N.W.2d 408, 411 (Wis. 1988); Love v. Love, 851 P.2d 1283, 1289 (Wyo. 1993). But see In re Marriage of Eckert, 518 N.E.2d 1041, 1047 (Ill. 1988); Domingues v. Johnson, 593 A.2d 1133, 1041 (Md. 1991).

472. See The Family Violence Project of the National Council of Juvenile and Family Court Judges, Family Violence in Child Custody Statutes: An Analysis of State Codes and Legal Practice, 29 FAM. L.Q. 197, 225-27 (1995) [hereinafter Family Violence Project].

473. See Barbara J. Hart, State Codes on Domestic Violence: Analysis, Commentary and Recommendations, 43 Juv. \& FAM. Cr. J. 3, 29, 34 (1992).

474. A number of studies have reported on the harm to children who witness domestic violence. For example, one study focused on 25 children who witnessed their mothers being abused. See Jane H. Pfouts et. al., Deviant Behaviors of Child Victims and Bystanders in Violent Families, in Exploring the Relationship Between Child Abuse and Delinquency $79-99$ (Robert J. Hunner \& Yvonne Elder Walker eds., 1981). Of the 25 children, $53 \%$ acted out with parents, $60 \%$ with siblings, $30 \%$ with peers, $33 \%$ with teachers; $16 \%$ had appeared in juvenile court, $20 \%$ were labeled truant, 58\% were below average or failing in school; caseworkers labeled $40 \%$ as anxious and $48 \%$ as depressed. See id. at 95; see also Bonnie E. Rabin, Violence Against Mothers Equals Violence Against Children: Understanding the Connections, 58 ALB. L. REv. 1109, 1111-14 (1995) (summarizing studies describing both direct and indirect harm to children living in homes where mothers are victims of domestic violence).

475. See Hart, supra note 473 , at 29.

476. See id; see also Family Violence Project, supra note 472, at 199. However, the majority of states still do not presume that a father who abuses the mother is unfit. See id. at 208.

477. See Family Violence Project, supra note 472, at 225-27. 
of violence. ${ }^{478}$

I have argued elsewhere that contemporary custody law still reflects a double standard for mothers. ${ }^{479}$ The custody law reforms I have described have not eliminated that double standard. Moreover, the overall effect of these statutes requires consideration of abuse to reduce the potential that children will be abused by a violent parent or will suffer from observing the abuse of their mothers.

The impact of these refinements to the "best interest standard" have not yet been evaluated, but the focus of these reforms on protecting children over furthering parents' rights should contribute to the overall trend toward a more child-focused custody law. Additionally, they "fost[er] a substantive vision of family life" in which "the role of the father is constitutive" involving shared responsibility in childraising. ${ }^{480}$

\section{The Child Support Revolution}

During the 1980s and 1990s, another "revolution" in family law has been taking place that has transformed child support law. ${ }^{481}$ Both the establishment and enforcement of child support were once primarily private matters where parents had the ability to contract between themselves for appropriate awards and were primarily responsible to initiate court actions to enforce those awards. ${ }^{482}$ Family law's increasing attention in recent decades on the protection of children, among other reasons, has led to increasing public responsibility for establishing and enforcing child support obligations. ${ }^{483}$

Blackstone described the duty of parents to provide for the support of their children as "a principle of natural law." 484 Traditionally, American divorce laws provided only vague guidance on postdissolution child support, using terms such as "suitable," "just," "reasonable," "proper,"

478. See id.

479. See generally Murphy, supra note 213 , at 693-702.

480. REGAN, supra note 90 , at 188.

481. See WeISBERg \& APPLETON, supra note 314 , at 763 (describing child support enforcement techniques as having "undergone a revolution in recent decades as a result of federal involvement").

482. See id. at 118. For an historical account of the development of child support law in this country from "moral duty to equitable remedy" see Garrison, supra note 76.

483. It is interesting to note that while different moral justifications are proffered for developments in spousal and child support, the two are very closely linked. Thus, while improvements in the establishment and collection of child support reflect a moral commitment to children, they are also justified by a similar commitment to their caretakers, often ex-spouses. See Glendon, TransformaTION, supra note 241 , at 198.

484. BLACKSTONE, supra note 146 , at $447-48$. 
"fit," "sufficient," or "necessary" to direct courts how to set an award. 485 Later, statutes listed factors to be considered in the exercise of judicial discretion to determine parental child support obligations. ${ }^{486}$

Until the 1980 s, laws governing child support were primarily a matter of state law and were generally framed as broad discretionary standards. ${ }^{487}$ Courts were free to set child support at any level as long as there was some indication that the finder of fact had considered the ability of the non-custodial parent to pay and the needs of the child[ren]. ${ }^{488}$

The inadequacy of most states' discretionary standards in setting initial child support awards took on critical proportions by the early 1980 's. ${ }^{489}$ Insufficient child support was a major cause of the spiraling poverty rate among women and children. ${ }^{490}$ When courts did award child support, award levels were often inadequate, thrusting many children and custodial parents into poverty or a seriously diminished standard of living. ${ }^{491}$ Studies estimating the costs of raising children in intact households demonstrate the inadequacy of such amounts of child support. ${ }^{492}$ In addition to the inadequacy of the award itself, the traditional system of virtually unlimited judicial discretion in this area led to "pronounced disparities in award amounts from court to court, from judge to judge, and

485. See VERNIER, supra note 185 , at 193.

486. For example, section 309 of the Uniform Marriage and Divorce Act allows courts to set an amount "reasonable or necessary," considering:

all relevant factors including: (1) the financial resources of the child; (2) the financial resources of the custodial parent; (3) the standard of living the child would have enjoyed had the marriage not been dissolved; (4) the physical and emotional condition of the child and his educational needs; and (5) the financial resources and needs of the noncustodial parent.

UNIF. MARRIAGE AND DivoRCE ACT § 309, 9A U.L.A. 573 (1998).

487. See Harry D. Krause, Child Support in Amertca: The Legal Perspective 10 (1981) ("[T]he court's discretion regarding the amount of child support usually reign[ed] supreme.").

488. See id.

489. See generally Murphy, supra note 15 , at 226-29.

490. Of the 9.4 million custodial parents in $1987,41 \%$ had no child support award. See Bu. reau of the Census, U.S. Dep't of Commerce, Current Population Reports, Series P-23, No. 167, Child SUPPORT AND AlumonY: 1987, at 1 (1990).

491. See Lucy Marsh Yee, What Really Happens in Child Support Cases: An Empirical Study of Establishment and Enforcement of Child Support Orders in the Denver District Court, 57 Devv. U. L. Rev. 21, 50 (1979). In 1987, the average child support for the 3.7 million custodial parents who actually received payments was \$2,710 per year. See BUREAU of THE CENSUS, supra note 490, at 1-2.

492. See, e.g., Jessica Pearson \& Nancy Thoennes, Will This Divorced Woman Receive Child Support?, Judges J. 40, 42-43 (1986) (describing the project that examined the child support implicaitons of various custody arrangements, and finding, among other things, that the level of support awarded in the cases examined fell "far below the costs of rearing children estimated by economists"). 
from case to case." ${ }^{493}$

The overall problem of inadequate awards, the lack of objective guidelines for establishing support obligations and the resulting inconsistencies in awards prompted reaction in both Congress and the White House, which framed the issue in moral terms. ${ }^{494}$ In response, beginning in the mid 1970s Congress enacted a series of related statutes addressing the child support problem. ${ }^{495}$ Both the substance and rhetoric surrounding these changes reflected the increased emphasis on duty and commitment to children. Probably the most important legislation from the perspective of moving toward guaranteeing children support was the Family Support Act of $1988 .{ }^{496}$ This Act required every state to establish presumptive child support guidelines as a condition for continued federal funding of the state's welfare program. ${ }^{497}$

A number of requirements of this statute strengthened the federal push for standardized child support decisions. Under this statute, each state had to adopt child support guidelines that presumptively established the appropriate child support obligation in any child support proceeding. ${ }^{498}$ As a result of this federal legislation, by 1990 every state had adopted some type of child support formula. ${ }^{49}$ In addition to providing

493. Sally F. Goldfarb, What Every Lawyer Should Know About Child Support Guidelines, 13 FAM. L. REP. 3031, 3032 (1987).

494. See H.R. REP. No. 98-527, at 49 (1983); see also President Ronald Reagan, Proclamation of National Child Support Enforcement Month, 1987 (Aug. 13, 1987) in 22 WeEkLY COMP. Pres. Doc. 939. ("[M]uch remains to be done to foster a nationwide conviction that child support represents not only a legal responsibility but a profound ethical obligation of parents and an urgent moral right of children.") While a significant factor in the initial push for federal intervention to strengthen child support was to reduce the federal welfare costs, the focus broadened to include a concern to reinforce parental duty to support children from all income groups. See Harry D. Krause, Child Support Reassessed: Limits of Private Responsibility and the Public Interest, in DivorCE REFORM AT THE Crossroads 166, 169-74 (Stephen D. Sugarman \& Herma Hill Kay eds., 1990).

495. For a description of these statutes, see Ann Laquer Estin, Federalism and Child Support, 5 VA. J. Soc. PoL'Y \& L. 541, 545-48 (1998).

496. Pub. L. No. 100-485, § 103, 102 Stat. $2346-48$ (1988).

497. See 45 C.F.R. $\S 301.10$ (1997) (stating that an approved state plan is a condition for federal financial assistance); id. $\S 302.56$ (a) (requiring that state plans contain child support guidelines). 498. See 42 U.S.C. $\$ 667(b)(2)$ (1994).

499. See Janice T. Munsterman et al. National Center for State Courts, Child Support GUidelines: A COMpendium Summary of ChIID SuPPoRT Guidelines (1990). The Income Shares Model, which the majority of states have adopted, employs various economic studies to identify the percentage of family income the child(ren) would have received if the parents lived together. The income of both parents is combined to calculate the basic child support obligation. See Irwin Garfinkel et al., Child Support Orders: A Perspective on Reform, in The Future of ChILden, Spring 1994, at 84, 87-88. This basic amount is then pro-rated between the parents in proportion to their respective incomes. See id. at 87-88. The noncustodial parent must pay his or her share as child support; the custodial parent presumably pays his or her share directly to the child(ren). See id. Because the eco- 
some uniformity to the method of establishing child support throughout the country, the Family Support Act signalled an important shift from child support law framed as a discretionary standard to child support framed as a rule or right. ${ }^{500}$

The Personal Responsibility and Work Opportunity Reconciliation Act of 1996 (PRWORA), ${ }^{501}$ imposed new requirements for child support enforcement. ${ }^{502}$ This controversial ${ }^{503}$ welfare reform legislation replaced a federal entitlement to welfare with a block-grant system. One commentator describes the attempt to establish child support as a right guaranteed to children under this new legislation: "The vision for child support enforcement that guided much of the development of the legislation is that the payment of child support should be automatic and inescapable-_like death or taxes." "504 Both the Family Support Act and the PRWORA statute followed much substantial debate in Congress that was often focused on the moral imperative of guaranteeing financial support for children..$^{505}$

Some commentators have interpreted these developments as evidence of family law's increasing concern for "caring and commitment" 506 by parents for their children. Additionally, these laws are further evidence that family law is not dominated by the ideology of liberal individualism ${ }^{507}$ to the extent that strengthening child support laws pushes

nomic studies of intact families suggest that families spend a decreasing percentage of total income on children as income levels increase, the guidelines provide for noncustodial parents at higher income levels to pay a declining percentage of income. See id. at 88-89. Additionally, most income shares formulas include cost-sharing for certain child-related expenditures such as child care and extraordinary medical expenses. See id. at 89.

500. The Act preserved limited judicial discretion by permitting judges to make a specific finding that application of the guidelines would be unjust or inappropriate in a particular case, as determined under criteria established by each state. See 42 U.S.C. \& 667 (b)(2) (1988).

501. Pub. L. No. 104-193, 110 Stat. 2105 (1996).

502. See id. \$§ 331-333.

503. See, e.g., Peter Edelman, The Worst Thing Bill Clinton Has Done, ThE ATLANTIC MoNTHLY, Mar. 1997, at 43-45.

504. Paul K. Legler, The Coming Revolution in Child Support Policy: Implications of the 1996 Welfare Act, 30 FAM. L.Q. 519, 538 (1996).

505. See, e.g., Welfare: Reform or Replacement? (Child Support Enforcement), Hearings on S.1511 Before the Subcomm. on Social Security and Family Policy of the Senate Finance Committee, 100th Cong. 273-308 (1987) (statements of J. Byran Hehir, U.S. Catholic Conference, and Charles V. Bergstrom, Lutheran Council in the USA in support of the Family Support Act of 1988; both emphasizing the moral issues involved in the elimination of child poverty); see also President Bill Clinton, State of the Union Address 1996 (emphasizing the moral obligation to pass federal welfare legislation that emphasizes responsibility of both parents for children).

506. Cahn, supra note 1, at 238 n.59; see also Galston, supra note 83 (describing increased efforts to enforce child support as an important part of the moral commitment to raise children well); Coltrane \& Hickman, supra note 416, at 412-17.

507. See Cahn, supra note 1 , at 270 . Interestingly, Carl Schneider predicted in 1985 that child 
parents in the direction of responsibility and away from self-fulfillment and autonomy.

Has the goal of strengthening parental obligation for support been realized? Research on the impact of the guidelines is mixed. Early reports indicated that guidelines had improved the status of custodial parents, ${ }^{508}$ but more recent studies have focused on the increasing rate of child poverty despite the imposition of guidelines and other child support reforms of the $1980 \mathrm{~s}^{509}$ However, most agree that fixed formulas for child support are a step in the right direction. ${ }^{510}$ Additionally, there are some signs that tougher child support enforcement laws are finally increasing collection of child support. ${ }^{511}$ Promising new proposals aimed at assuring more generous and uniform child support awards are being developed by scholars and policymakers. ${ }^{512}$ These developments and suggestions for future refinements evidence the trend toward reinforcing responsibility and commitment to children. Together with the changes

support law was moving in a direction in which the increasing public responsibility for child support was undermining parental responsibility for children. See Schneider, Moral Discourse, supra note 1, at 1813 . While recognizing "evidence to the contrary," he supported his claim by pointing to the abysmal record for child support collection that existed at that time. Id. at 1812. In the intervening years, both improvements in child support collection and the shift from public to private responsibility as evidenced by PRWORA indicate a strengthening of parental duty under the law.

508. See, e.g., Irwin Garfinkel et al., Child Support Guidelines: Will They Make a Difference?, $12 \mathrm{~J}$. FAM. Issues 404, 405 (1991) (predicting that award levels would rise upon implementation of the guidelines); Murphy, supra note 15 , at 232 ("The consensus . . . is that [thel guidelines are working."); Nancy Thoennes et al., The Impact of Child Support Guidelines on Award Adequacy, Award Variability, and Case Processing Efficiency, 25 FAM. L.Q. 325, 332 (1991) (citing studies showing increased awards after implementation of the guidelines).

509. See, e.g., Garrison, supra note 76, at 63 (summarizing data showing that guidelines "have not dramatically improved the lot of children eligible for child support").

510. See id. at 101.

511. See, e.g., Elaine Sorenson \& Ariel Halpern, Single Mothers and Their Child SupPORT RECEIPT: How WELL IS CHILD SUPPORT DoING? (Urban Institute 1999) (finding that nevermarried mothers increased their rate of child support receipt from $4 \%$ in 1976 to $18 \%$ in 1997); Ann Marie Rotondo, Comment, Helping Families Help Themselves: Using Child Support Enforcement to Reform Our Welfare System, 33 CAL. W. L. REv. 281, 282-84 (1997); see also Michael Holmes, Millions Culled in Child Support, Hous. ChroN. Sept. 10, 1996, at 20.

512. See, e.g., American Law Institute, Principles of the Law of Family Dissolution: Analysis and Recommendations $\S 3.04,3.05 \mathrm{~B}$ (Preliminary Draft No. 7 vol. I, June, 1997) (advocating an Equal Living Standard Model for child support to ensure that the supported child enjoys a standard of living that is at least equal to that of the non-custodial parent); Garrison, supra note 76, at 117 (arguing for the adoption of a "Community Model" which bases the support obligation on "family membership" and "mandates income sharing as the basic approach"); Murphy, supra note 213, at 728-730 (arguing for voluntary impoverishment rules which are more generous to caretakers of young children); see also Harry D. Krause, Review of Part X, Child Support, 92d Cong., 2d Sess., Soc. Sec. Am. of 1972, Committee on Finance, U.S. Senate, H.R. 1 (unpublished consultant's paper) 52-53 (advocating a uniform federal formula related to the non-custodial parent's ability to pay). 
identified in custody law that promote deeper involvement of fathers in child rearing, these child support reforms are a step in the direction of creating laws that encourage parents' fulfillment of the moral commitment to support their children. ${ }^{513}$

\section{Creating Rights for Family Members: From Discretionary Standards to Rules}

Standards in family law for allocating family assets, deciding child custody and visitation, child support and alimony have traditionally been characterized by broad discretion. ${ }^{514}$ Over the last two decades, several developments in family law have signalled a shift from broad standards to rules. ${ }^{515} \mathrm{~A}$ brief history of the development of discretionary standards illuminates the ways in which such a shift holds promise for protecting vulnerable family members.

Discretion in domestic law has its origins in the concept of the equity court. ${ }^{516}$ Equity courts were established to replace a system of justice that applied rigid rules in the courts of law with a system that permitted some measure of discretion. ${ }^{517}$ It was believed that rigidity was the mark of a primitive legal order. ${ }^{518}$ Citizens thought that the law courts could no longer dispense justice. ${ }^{519}$ Inflexible application of rules forced the parties to go to the king for relief. The king appointed chancellors to provide the individualized justice that rigid courts of law could not; the chancellors' authority gradually developed into the equitable Court of Chancery. ${ }^{520}$

The use of discretion continued to grow in most areas of Anglo-

513. See Furstenberg \& CherLin, supra note 401, at 104, $118-19$.

514. This discussion is based, in part, on Murphy, supra note 15, at 212-14, 218-19.

515. Some commentators have analyzed changes in trends in family law over the same time period and interpreted the balance between rules and discretion as "moving simultaneously in both directions." Judith T. Younger, Marriage, Divorce and Family: A Cautionary Tale, 21 HorsTRA L. REv. 1367, 1376 (1993); see also Carl E. Schneider, The Tension Between Rules and Discretion in Family Law: A Report and Reflection, 27 FAM. L.Q. 229 (1993).

516. See, e.g., KenNeth Davis, Discretionary Justice: A PREliminary INQuiRy 18 (1969).

517. See id. at 19.

518. See Henry S. Maine, Ancient Law: Its Connection With the Early History of SoclETY, AND ITS RELATION TO MODERN IDEAS 65-69 (5th ed. 1888); REgAN, supra note 90, at 188.

519. See, e.g., DAvis, supra note 516, at 19; see also JOSEPH STORY, 1 COMMENTARIES ON EQUTTY JURISPRUDENCE, AS ADMINISTERED IN ENGLAND AND AMERICA 29-31 (photo reprint) (1877) (reviewing the British roots of the American courts of equity).

520. However, in time, the Chancery Court developed its own rules to guide the exercise of discretion. See Davis, supra note 516, at 19 . Thus, the recognition that rules should be developed to avoid arbitrariness and inequity has always tempered the ideal of individualized justice through the exercise of discretion. 
American law.521 Given the complex issues of human behavior underlying child placement and other family law issues, it is not surprising that reliance on the exercise of judicial discretion became particularly prevalent in family law. Increasingly, discretion replaced the development of meaningful standards and rules in state regulation of the family. In contrasting family and property law, for example, Mary Ann Glendon has noted:

In our legal system, property law traditionally has been and even now continues to be characterized by a high degree of strict law, due to what are generally thought to be special needs in that field for stability, predictability, and security of titles. Family law, on the other hand, is characterized by more discretion than any other field of private law. This fact is typically explained by a perceived need to tailor legal resolutions to the unique circumstances of each individual and family. However, when the fields of property and family law intersect, as they frequently do, especially when a family is dissolved by divorce or death, difficult questions arise concerning the proper accommodation of the interests served by rules establishing "bright lines" and those furthered by individualizing discretion. ${ }^{522}$

Commentators have offered a variety of rationales for the persistent hold of discretion on family law in addition to the general argument that individualized decisions are necessary given the complexity and diversity of families appearing before the court. ${ }^{523}$ One commentator attributes the rise of judicial discretion to the distinctly local nature of family law jurisprudence. 524 Because "state domestic relations chauvinism" produced conflicts among state family codes, judges had to develop a "loosely arranged set of national domestic relations doctrines" to harmonize local law. ${ }^{525}$ These vague doctrines allowed judges to assume a "patriarchal stance by evaluating state legislation in terms of their perception of family needs, community interest, and national common law priorities." 526

Perhaps the most compelling explanation for the strong reliance on discretion in family law comes from feminist legal scholars. ${ }^{527}$ Mary

521. See id. at 20.

522. Mary Ann Glendon, Fixed Rules and Discretion in Contemporary Family Law and Succession Law, 60 TuL L. REv. 1165, 1167-68 (1986) (footnote omitted); see also Schneider, supra note 195, at 2228-31 (discussing the vagueness of family law standards).

523. See NEELY, supra note 412 , at 34-38.

524. See Grossberg, supra note 283 , at 819 .

525. Id. at 819 .

526. Id. at 820 .

527. See, e.g., Glendon, TRANSFORMATion, supra note 241, at 232; Glendon, supra note 522, at 1176-77 (observing that judicial discretion reflects a reluctance to impose significant burdens on an absent father in order to force him to support his children); Schneider, supra note 195, at 221926; Scott, supra note 325 , at 9,34 n.75 (arguing that reluctance to increase child support results from judicial ignorance of the actual costs of raising children). 
Becker, for example, contrasts family and contract law and offers a gender-based explanation for the rights versus discretion dichotomy in these two areas. ${ }^{528}$ At the beginning of the nineteenth century, the ideal of individualized discretionary justice played a significant role in contract law remedies. Juries set damages with few, if any, fixed rules; their only guidance was a nebulous admonition to reach an appropriate decision in light of the actual injuries, needs, and abilities of the parties to the contract. ${ }^{529}$ However, since that time courts and legislatures have developed rules that severely limit the jury's discretion. ${ }^{530}$ Becker notes that no similar movement to curb the "virtually unbounded" discretion in the area of family law has occurred. ${ }^{531}$ She suggests that the greater tolerance of discretion in family law than in commercial cases is attributable to the gender of the parties seeking relief. ${ }^{532}$

When a commercial relationship collapses, the parties seeking relief tend to be male. In contrast, when a family relationship collapses, it is primarily women who tend to need and seek remedies such as alimony, child custody, and support. ${ }^{533}$ Judges and legislators, who are still overwhelmingly male, ${ }^{534}$ are more willing to fashion rules to enforce the bargains men strike in commercial relationships, because they identify and empathize with the parties and place value on the transactions at issue. However, these decision makers neither value or understand the choices made by women seeking relief following the termination of a marital relationship. These women are often traditional homemakers who agreed to defer or give up career opportunities and income potential to raise children and provide a home for the family in exchange for financial and

528. Mary Becker, Transcript of Address at 1989 American Association of Law Schools Annual Meeting (Jan. 6, 1989).

529. See E Allan Farnsworth, Contracts $\$ 12.8$, at 840 (1982).

530. See, e.g., Perfecting Serv. Co. v. Prod. Dev. \& Sales Co., 131 S.E.2d 9, 22 (N.C. 1963) ("Absolute certainty is not required but evidence of damages must be sufficiently specific and complete to permit the jury to arrive at a reasonable conclusion.") (quoting Tillis v. Calvine Cotton Mills, Inc., 111 S.E.2d 606, 612 (N.C. 1959)).

531. Becker, supra note 528 .

532. See id.

533. Mothers are most often the custodians of children in single parent families. The majority (88\%) of children living in single parent homes live with their mother. See SALUTER, supra note 363, at ix; see also WorkING GRoup on WeLfare ReForm, FAMILY SUPPoRT, AND INDEPENDENCE, U.S. Dep't of Health \& Human Servis. Background Papers on Welfare Reform: Child Support ENFORCEMENT 3 (1994) (citing a similar statistic).

534. See Center for the AMerican Women and Polictics. Fact Sheet (1999) (finding that 22.3\% of state legislators are women in 1999); WOMEN IN THE LAW: A LOOK AT THE NUMBERS 31 (American Bar Association, Dec. 1995) (finding that in 1991, 7\% of federal court judges and 9\% of state court judges were women). 
emotional support from their husbands. In this situation the discretionary standards-giving primarily male judges control over women's income from ex-husbands-have resulted in retention by men of a disproportionate share of family assets after divorce. ${ }^{535}$ Thus, Becker maintains that discretionary standards are used to reinforce male power and female subordination by keeping women subject to and dependent upon the judgment of mostly male judges. ${ }^{536}$

The alternative to the near total reliance on discretionary standards in family law is the infusion of some rules that will more effectively secure the obligations family members owe one another. ${ }^{537}$ Scholars with a variety of perspectives have discouraged rules and individual rights in family law. Communitarians have argued that an emphasis on privacy and individual rights undermines strong families. As Michael Sandel puts it: "[In] a more or less ideal family situation, where relations are governed in large part by spontaneous affection ... individual rights . . . are seldom invoked, not because injustice is rampant but because their appeal is preempted by a spurt of generosity." 538

Many feminist scholars also believe that rules and rights should be discouraged in families. From their perspective, rules favor established

535. See Glendon, TRANSFormation, supra note 241, at 232 (arguing that today's judges, in exercising their "virtually uncontrolled discretion," tend to protect the former husband's standard of living).

536. See Becker, supra note 528; see also Barbara Stark, Divorce Law, Feminism, and Psychoanalysis: In Dreams Begin Responsibilities, 38 UCLA L. REv. 1483, 1516, 1518 (1991) (noting both that the "law itself is 'male,' representing and incorporating male values" and that "judges have tremendous discretion in divorce cases" in this country).

537. Of course, rules can be used to reinforce patriarchy and consolidate power and authority in a single family member. Prior to the adoption of equitable distribution statutes to allocate property after divorce, most states used a rule dividing property by title. See KRAuSE ET AL., Family LAw: CASES, COMMENTS, QUESTIONS 719 (1998). This method of distribution of property meant most property went to husbands after divorce. See id. Similarly, prior to the adoption of the best interests standard for child custody decisions, a paternal presumption governed custody cases. See Polikoff, supra note 461 , at $235-36$. These rules do not work to protect vulnerable family members and the shift away from them generally helps custodial parents and children.

538. Michael J. Sandel, Liberalism and the Limits of Justice 33 (1982); see also Jean Bethre Elshtain, A Communitarian Position on the Family. National Civic Review 25-35 (1991); Galston, supra note 83; MARY ANN GLENDON, THE NEW FAMILY AND the NEW PROPERTY 42 (1981) (describing the "emergence of the self-determining, separate individual from the network of family and group ties"); Bnuce C. Hafen, The Constitutional Status of Marriage, Kinship, and Sexual Privacy; Balancing the Individual and Social Interests, 81 MiCH. L. Rev. 463, 464-72, 496-501 (1983) (criticizing individual rights analysis of family relationships while stressing the importance of traditional marital family); John Hardwig, Should Women Think in Terms of Rights, 94 ETHICs 441, 448 (1984) (examining the relationship between rights and close-knit communities and concluding that "thinking in terms of rights systematically denies the unity, the togetherness, the "we" that we are trying to create"). 
hierarchies and do not conform with women's experiences. ${ }^{539}$ However, a growing number of feminists have urged a reconception of rights that can protect vulnerable family members and take precedence over family privacy rights when the two sets of rights conflict. ${ }^{540}$ Susan Okin has urged policymakers to recognize that "however much the members of families care about one another and share common ends, they are still discrete persons with their own particular aims and hopes, which may sometimes conflict. [W] must see the family as an institution in which justice is a crucial virtue." 541

In analyzing the shifts between discretion and rules in the no-fault era, it is true that we seem to "be moving simultaneously in both directions." 542 However, a close examination of the underlying changes in the law as a result of these shifts suggests a move towards rules when they are needed to secure rights for vulnerable members of families.

Of course the movement from discretion to rules for divorce grounds started this trend. ${ }^{543}$ While the retention of fault grounds in most states has meant continued reliance on discretion in some divorce cases, statutes that permit unilateral or consent divorces after a waiting period can be classified as rules. ${ }^{544}$ Many commentators have claimed that the easier access to divorce has hurt women and children. ${ }^{545}$ Others argue

539. See generally Carol Gilligan. In A DifFerent VoICe 64-105 (1982) (reporting on research demonstrating that reliance on rules and rights is more common in the male experience). Within the more specific debate about achieving fairness for women when families divorce, other feminist scholars maintain that a decisionmaking model that recognizes the complexity of relationships has more promise. See Karen Czapanskiy, Gender Bias in the Courts: Social Change Strategies, 4 GEO. J. LEGAL ETHCS 1, 8-12 (1990).

540. See Jane Rutherford, Beyond Individual Privacy: A New Theory of Family Rights, $39 \mathrm{U}$. FLA. L. REv. 627, 643-44 (1987) (arguing that rights belong both to the family as a group, and to each individual family member and when competing rights need to be accommodated, the rights of the weaker party should take priority over the privacy rights of the family).

541. SUSAN M. OKIN, JUSTICE, GENDER AND THE FAMILY 32 (1989); see also Garrison, supro note 76 , at 46 , arguing that:

The lack of an established ethical tradition relating to child support may help to explain policy makers' failure to articulate a theoretical basis for current support guidelines, but does not excuse it. In a society in which law will prescribe the economic relationships of at least half of the children and their parents, we cannot afford to disregard issues of justice between family members. The family as a set of affective and altruistic relationships may lie beyond the realm of justice, but family law most certainly does not.

542. Younger, supra note 515, at 1376; see also Schneider, supra note 515, at 229.

543. Application of fault-based grounds for divorce involve substantial judicial discretion. See supra notes 110, 114-149 and accompanying text. No-fault grounds, on the other hand, which involve proof of more objective facts like the length of separation, require little or no judicial discretion in their application. See supra notes 328-29 and accompanying text.

544. See supra notes 383-84 and accompanying text.

545. See supra note 406 and accompanying text. 
that these no-fault grounds have achieved the goals of reducing acrimony and trauma to families, particularly children, experiencing divorce. ${ }^{546}$ In abusive marriages, the evidence is quite clear that easier access to divorce protects women and children. . $^{57}$

The most significant shift from discretion to rules in the no-fault era has been in the area of child support. ${ }^{548}$ The rules that have resulted in the move from a broad standard to fixed formulae for establishing child support certainly need to be refined. ${ }^{549}$ However, the new child support rules have secured rights for children. The debate about the rules and the resulting standards have also communicated the message that noncustodial parents should take responsibility for their children, even when the obligation to support significantly inhibits personal autonomy.

Limited acceptance of the primary caretaker rule to replace the broad discretionary best interests standard for child custody decisions represents a similar trend. ${ }^{550}$ Some have advocated the adoption of this rule from a perspective of fairness to mothers. ${ }^{551}$ Others argue that applying the rule will be less costly and reduce delays for litigants. ${ }^{552}$ However, most of the support for this rule, comes as a result of the research demonstrating that it protects children better than the indeterminate best interests standard. ${ }^{553}$

Developments in alimony law in the last decade also reveal substantial support for discarding the prevailing discretionary standard and moving to a rule based approach. A number of proposals emphasize income sharing to equalize the post-divorce standards of living. ${ }^{554}$ The widely circulated and debated ${ }^{555}$ American Law Institute Principles of the Law of

546. See supra notes 395,407 and accompanying text.

547. See Furstenberg \& Cherlin, supra note 407.

548. See supra notes $481-513$ and accompanying text.

549. See id.

550. See supra notes $458-63$ and accompanying text.

551. See Becker, supra note 461, at 175-83. But see Schneider, supra note 195, at 2215, 2216 (discussing judicial discretion in custody cases and arguing that, despite its weaknesses, the best interest standard should be retained).

552. See Murphy, supra note 386, at 133-34.

553. See supra notes $457-80$ and accompanying text.

554. See Jane Rutherford, Duty in Divorce: Shared Income as a Path to Equality, 58 Ford. HAM L. Rev. 539, 563-64, 573, 578-83, 592 (1990); Jana Singer, Alimony and Efficiency: The Gendered Costs and Benefits of the Economic Justification for Alimony, 82 GEo. LJ. 2423 (1994); Stephen D. Sugarman, Dividing Financial Interests at Divorce, in DIVORCE REFoRM AT THE CROssROADS 159-60 (Stephen D. Sugarman \& Herma H. Kay eds., 1990) (proposing a system in which each spouse's interest in post-divorce income would be based on the length of marriage).

555. See J. Thomas Oldham, ALI Principles of Family Dissolution: Some Comments, 1997 U. ILL. L. Rev. 801 (1997); Carl Schneider, Rethinking Alimony? Marital Decisions and Moral Dis- 
Family Dissolution (ALI principles) ${ }^{556}$ have developed alimony formulae, which have compensation of a spouse for financial loss arising from the dissolution of the marriage as one of its principal goals. ${ }^{557}$ The ALI principles emphasize fairness and encourage sharing rather than need or fault. The goal of these principles is to return spouses to their premarital situations in short marriages and, in longer marriages to compensate financially vulnerable spouses for their marital investment. Another major theme of the principles is to replace the discretionary alimony system with a more rule-based one.

Some rule-based formulae for property distribution and alimony have found their way into law. ${ }^{558}$ Research on their impact to achieve the goals of fairness, equality or protection of vulnerable family members is yet to be done. These proposals, along with the child support and custody rules already in place, offer the promise of securing commitment and responsibility among family members.

\section{CONCLUSION}

Family law has undergone substantial changes since the first "no fault" divorce statute in 1970. These changes have reduced the role of fault in divorce, custody, visitation and alimony. This diminished role of fault has reduced the emphasis in family law on sexual misconduct. Because family law jurisprudence has traditionally labelled sexual misconduct issues as "moral," cases and statutes since the adoption of no-fault divorce have fewer explicit references to morality. This change in the language of family law, along with increases in both rates of divorce and single-parent families over the last three decades, have caused both policymakers and scholars to comment on the decline of morality in family law. This Article has challenged the assumption that the decline in the role of fault has meant diminished emphasis on morality in either the language or the substance of family law.

Two streams of contemporary thought have informed the understanding of the term morality. The first, which has been developed by contemporary moral philosophers building on the classical tradition,

course, 1991 BYU L. Rev. 197 (1997); Swisher, supra note 388, at 298-300.

556. American LaW Institute, Principles of the LaW of Family Dissolution: ANalysis and Recommendations, Tentative Draft No. 2 (Mar. 14, 1996) [hereinafter Ali Principles].

557. See id.

558. See 31 Minn. Rev. Stat. AnN. § 518.6111 (West Supp. 1999); Mich Comp. Laws Ann. $\S 722.3$ (West Supp. 1998); Gregory J.M. v. Carolyn A.M., 442 A.2d 1373, 1377 (Del. 1982); Ball v. Minnick, 648 A.2d 1192, 1196-97 (Pa. 1994). 
teaches that morality is about practicing virtues. There is much debate within this group of communitarian philosophers about the degree to which certain virtues have universal appeal; the importance of different virtues varies among cultures and changes over time. However, there is some consensus that caring for children is a core feature of most societies' moral systems. Within the context of contemporary American family law, there is much evidence that caring for children has become the moral imperative.

The second stream of thought relates to rights and their connection to morality. A substantial body of commentary suggests that "rights talk" is hostile to the notions of care and interconnectedness that are essential to the family and its role in protecting children. But the concept of rights has been reconceived by feminists and others to emphasize protection of vulnerable and dependent family members, especially children. This conception of rights rejects the focus on autonomy in traditional liberal rights discourse and is compatible with more communitarian values.

This scholarship, which suggests a broader meaning of morality and rights, has revealed the substantial limitations in the view of morality during the fault-era. The emphasis on sexual conduct during the fault-era combined with broad discretionary standards, reinforced traditional gender roles in family law and contributed to inadequate financial support for custodial parents and children. The broader concept of morality, with its emphasis on the virtues of care and protection of children, has provided both a new language for moral discourse and a new perspective from which to evaluate developments in family law over the last three decades. While some of these developments address issues that are more traditional "moral" issues, such as the meaning of commitment in marriage, others address issues that are more commonly thought of as economic or psychological issues, such as how to guarantee adequate support for children and how to evaluate parental fitness.

Still other developments have brought family law into an area that the law declined to regulate during the fault era-preventing family abuse. Finally, the emerging shift from discretion to rules on key issues involving children evidences a new understanding that the concept of rights is not anti-family; rather, strengthening the laws that express the commitments family members owe to another, particularly parents to children, can strengthen families. All of these changes have a moral dimension and enhance the virtues of commitment and responsibility, particularly to children. 
Creating a family policy 559 that fulfills what I have characterized as the central moral imperative of family law, protection of children, is an ambitious goal that is still unrealized. ${ }^{560}$ Despite the widespread rhetoric suggesting that this country sees our children as its greatest resource, ${ }^{561}$ there is still an enormous gap between that rhetoric and the existence of policies that protect children. ${ }^{562}$ Much of the gap can be attributed to the large costs associated with issues like adequate health care and child care. ${ }^{563}$ But part of the gap can be attributed to a lack of consensus about how to achieve the goal of protecting children.

A number of areas of the law have a critical role to play. Welfare law, labor law, social security law and tax law, all play a significant role in the well-being of children. However, family law still has a leading role to play in improving the lives of children. If the focus of family law is returned to punishing the sexual misconduct of married couples there will be little hope that this area of the law will improve the lives of children. The developments outlined in this Article-child custody and visitation laws that evaluate parental fitness based on their capacity to harm or help their children rather than on their sexual misconduct; laws that provide legal protection to family members who are abused by other family members; child support that is predictable and more widely enforced-all have the potential of promoting the moral goal of protecting children. Future refinements of these laws are needed but should be evaluated from a perspective that incorporates both the concepts and the language of this new morality in family law.

559. Family policy can be broadly defined as "objectives concerning family well-being and the specific measures taken by governmental bodies to achieve them." Jacqueline B. Stanfield, Family Policy in America: A Continuing Controversy, 50 Rev. of Soc. Econ. 420, 424 (1992) (citing Joan Aldous \& Wilfried Dumon, Family Policy in the 1980s: Controversy and Consensus, in CoNTEMPORARY FAMILIES: LOOKING FoRWARD LOOKING BACK (Alan Booth ed., 1991)).

560. As one commentator put it, despite the emphasis on children's welfare in contemporary family law, "[o]ur society does not embrace a child-centered morality generally." Altman, supra note 80 , at 346 .

561. See, e.g., Hillary Rodham Clinton, It Takes a Village: and Other lessons ChiDREN TEACH Us 318 (1996) ("[N]othing is more important to our shared future than the well-being of children.").

562. See, e.g., Kids Count: State Profles of Child Well-Being (Annie E. Casey Foundation 1997) (finding that children growing up in poor communities today "face tough odds" including being at greater risk of being sick and having inadequate health care; of being parents before they complete school; of being users of easily available drugs; of being exposed to violence; and of being incarcerated before they are old enough to vote).

563. See Gilbert Steiner, Looking for Family Policy—Big Tickets on Moral Judgments, in THE Politics and Programs of Family Policy. Center for the Study of Man (J. Aldous \& W. Dumon eds., 1980). 